\title{
Phytosociological analysis of montane- subalpine dwarf willow shrub communities in the Julian Alps and on the Trnovski gozd plateau (NW and W Slovenia)
}

\section{Igor Dakskobler ${ }^{1} \&$ Boštjan Surina ${ }^{1}$}

Key words: phytosociology, synsystematics, Elyno-Seslerietea, Rhododendro hirsuti-Ericetea carneae, Betulo carpaticae-Alnetea viridis, Julian Alps, Dinaric Alps, Trnovski Gozd Plateau, Snežnik Mts., Slovenia.

Ključne besede: fitocenologija, sinsistematika, Elyno-Seslerietea, Rhododendro hirsuti-Ericetea carneae, Betulo carpaticae-Alnetea viridis, Julijske Alpe, Dinarsko gorstvo, Trnovski gozd, Snežniško pogorje, Slovenija.

Received: 28. 2. 2017

Revision received: 28.4 .2017

Accepted: 5. 5. 2017

\begin{abstract}
By means of a phytosociological analysis of 72 relevés of montane-subalpine shrub communities with dominating Rhododendron hirsutum, Salix waldsteiniana, S. glabra and S. appendiculata from the Julian Alps and the the Trnovski Gozd Plateau and by comparing them with similar communities elsewhere in the Alps and the Dinaric Alps we described a new association Laserpitio peucedanoidis-Salicetum waldsteinianae, a new subassociation Rhododendretum hirsuti vaccinietosum myrtilli, two new subassociations of the association Dryado-Rhodothamnetum chamaecisti that had recently been described in the Dolomites (-caricetosum firmae, -salicetosum waldsteinianae), as well as a new association Heliospermo pusillae-Rhododendretum hirsuti. We classified the glabrous willow community in the study area into a new association Homogyno sylvestrisSalicetum glabrae and proposed a new name - Rhododendro hirsuti-Salicetum appendiculatae for the large-leaved willow community, which we subdivided into two geographical variants: var. geogr. Paederota lutea (Julian Alps, Trnovski Gozd Plateau) and var. geogr. Hypericum grisebachii (Liburnian Karst).
\end{abstract}

Izvleček

S fitocenološko analizo 72 popisov gorsko-subalpinskih grmišč s prevladujočimi vrstami Rhododendron hirsutum, Salix waldsteiniana, S. glabra in S. appendiculata $\mathrm{v}$ Julijksih Alpah in Trnovskem gozdu in primerjavo s podobnimi združbami drugod v Alpah in v Dinarskem gorstvu smo opisali novo asociacijo Laserpitio peucedanoidis-Salicetum waldsteinianae, novo subasociacijo Rhododendretum hirsuti vaccinietosum myrtilli in dve novi subasociaciji asociacije Dryado-Rhodothamnetum chamaecisti, ki so jo nedavno opisali v Dolomitih (-caricetosum firmae, -salicetosum waldsteinianae), v Trnovskem gozdu pa novo asociacijo Heliospermo pusillaeRhododendretum hirsuti. Združbo gole vrbe v raziskanem območju uvrščamo v novo asociacijo Homogyno sylvestris-Salicetum glabrae, za združbo velikolistne vrbe pa predlagamo novo ime Rhododendro hirsuti-Salicetum appendiculatae in jo členimo v dve geografski varianti: var. geogr. Paederota lutea (Julijske Alpe, Trnovski gozd) in var. geogr. Hypericum grisebachii (Liburnijski kras).

1 Institute of Biology, Scientific Research Centre of the Slovenian Academy of Sciences and Arts, Regional unit Tolmin, Brunov drevored 13, SI-5220 Tolmin and Biotechnical Faculty of the University in Ljubljana, Department of Forestry and Renewable Forest Resources, Večna pot 83, SI-1000 Ljubljana, Slovenia. E-mail: igor.dakskobler@zrc-sazu.si

2 University of Primorska, Faculty of Mathematics, Natural Sciences and Information Technologies, Glagoljaška 8, SI-6000 Koper, Slovenia and Natural History Museum Rijeka, Lorenzov prolaz 1, 51000 Rijeka, Croatia. E-mail: bostjan.surina@prirodoslovni.com 


\section{Introduction}

Until recently, communities of hairy alpenrose (Rhododendron hirsutum) and Waldstein willow (Salix waldsteiniana) in the Julian Alps were studied mainly by Zupančič \& Žagar (2001) and Surina (2005a), while the role of large-leaved willow (Salix appendiculata) was indirectly discussed in descriptions of communities with dominating Alnus viridis (Dakskobler et al. 2013a), Rhamnus fallax (Dakskobler et al. 2013b) and Sorbus aucuparia (Dakskobler 2016). Subalpine shrub communities with dominating Juniperus alpina and Rhododendron hirsutum in the Southeastern Alps (Poldini et al. 2004) and in the northwestern part of the Dinaric Alps (Surina 2013), on the other hand, have been thoroughly studied. The studied communities usually overgrow specific sites (shady slopes with persistent snow cover, stony depressions, gullies, hollows and limestone pavements). Very often they are long-term successional stages on screes or rockfalls. Compared to the dominating forms of shrub vegetation in the subalpine belt of the Southeastern Alps (dwarf pine, green alder stands) they do not overgrow large areas, but their ecological role is similar and important, both in terms of their protective and biotope function. Over the last 15 years we have collected a lot of relevé material. We arranged the collected relevés into a phytosociological table, mutually compared them and classified the established communities into a syntaxonomic system.

\section{Methods}

Subalpine shrub communities in the Julian Alps and on the Trnovski Gozd Plateau were studied applying the Braun-Blanquet method (Braun-Blanquet 1964). A total of 72 relevés (12 of which had already been published - 11 relevés by Surina 2005a and one by T. Wraber 1980) were entered into the FloVegSi database (Fauna, Flora, Vegetation and Paleovegetation of Slovenia) of the Jovan Hadži Institute of Biology at SRC SASA (Seliškar et al. 2003). The phytosociological relevés were arranged into a working table based on hierarchical classification. We transformed the combined cover-abundance values with numerical values (1-9) according to van der Maarel (1979). Numerical comparisons were performed with the SYN-TAX 2000 program package (Podani 2001). The relevés were compared by means of "(unweighted) average linkage method" - UPGMA, using Wishart's similarity ratio.

In the first step we used the numerical analyses as the basis on which we formed floristically homogeneous groups of relevés that were subsequently compared, using the same methodology, with similar communities in the Eastern Alps and the Dinaric Alps, also using hierarchical classification and the same method as when we compared individual relevés.

The nomenclature source for the names of vascular plants are the Mala flora Slovenije (Martinčič et al. 2007) and Flora alpina (Aeschimann et al. 2004a,b), and for mosses Martinčič $(2003,2011)$. Suppan et al. (2000) is the nomenclature source for the names of lichenicolous fungi (lichens). Only the most frequent taxa were determined for mosses and lichens, some only to the rank of genus. For the names of syntaxa we follow Grabherr et al. (1993), Theurillat (2004), Karner (2007a), Šilc \& Čarni (2012), E. Pignatti \& S. Pignatti (2014) and Mucina et al. (2016). In the classification of species into phytosociological groups (groups of diagnostic species) we mainly refer to the Flora alpina (Aeschimann et al. 2004a,b). The geographic coordinates of relevés are determined according to the Slovenian geographic coordinate system D 48 (5th zone) on the Bessel ellipsoid and with Gauss-Krüger projection.

Most of the relevés discussed in this article were made in the Julian Alps and on the Trnovski Gozd Plateau (Dinaric Alps). The geological bedrock in the study area is mainly calcareous, limestone, dolomite limestone or dolomite (Buser 2009). The studied communities occur on initial soils (lithosols) or rendzina with raw or moder humus (Lovrenčak 1998, Vidic et al. 2015). The climate is montane, humid, with mean annual precipitation of $(2,000) 2,500$ to $3,000 \mathrm{~mm}$ (Zupančič 1998) and mean annual air temperature of $(-1) 0$ to $+2{ }^{\circ} \mathrm{C}$ (Cegnar 1998). As the studied communities overgrow mainly shady slopes and hollows their stands are frequently covered with snow for several months.

\section{Results and discussion}

\section{Review of the syntaxa, with types of newly described communities}

\author{
Elyno-Seslerietea Br--Bl. 1948 \\ Seslerietalia coeruleae Br.-Bl. in Br.-Bl. et Jenny 1926 \\ Caricion firmae Gams 1936 \\ Dryado-Rhodothamnetum chamaecisti E. Pignatti,
}

Pignatti et Gerdol in E. Pignatti et Pignatti 2014

- caricetosum firmae subass. nov. hoc loco, the nomenclature type, holotypus, is relevé 8 in Table 1.

- salicetosum waldsteinianae subass. nov., the nomenclature type, holotypus, is relevé 16 in Table 1

Rhododendro hirsuti-Ericetea carneae Schubert et al. 2001 Rhododendro hirsuti-Ericetalia carneae Grabherr, Greimler et Mucina 1993

Ericion carneae Rübel ex Grabherr, Greimler et Mucina 1993 
Rhodothamno chamaecisti-Juniperetum alpini Poldini, Oriolo et Francescato 2004

Rhododendro hirsuti-Juniperetum alpinae Horvat ex Horvat et al. 1974

Rhododendretum hirsuti Lüdi 1921 vaccinietosum myrtilli subass. nov., the nomenclature type, holotypus, is relevé 27 in Table 1

Heliospermo pusillae-Rhododendretum hirsuti ass. nov. hoc loco, the nomenclature type, holotypus, is relevé 2 in Table 4

Homogyno sylvestris-Salicetum glabrae ass. nov. hoc loco, the nomenclature type, holotypus, is relevé 7 in Table 4

Betulo carpaticae-Alnetea viridis Rejmánek in Huml et al. 1979 Alnetalia viridis Rübel ex Huml et al. 1979

Alnion viridis Schnyder 1930

Aceri-Salicetum appendiculatae Oberdorfer 1957

Salicetum waldsteinianae Beger ex Oberdorfer 1978

Salicetum glabrae Smettan ex Eggensberger 1994

Laserpitio peucedanoidis-Salicetum waldsteinianae

Zupančič et Žagar ex Dakskobler et Surina ass. nov. hoc loco, the nomenclature type, lectotypus, is relevé 7 in Table 1 (Zupančič \& Žagar 2001), syn.: Salicetum waldstenianae Beger corr. Zupančič et Žagar 2001 var. geogr. Homogyne sylvestris Zupančič et Žagar 2001

-typicum, the nomenclature type is the same as the nomenclature type of the association

- saxifragetosum rotundifoliae subass. nov. hoc loco., the nomenclature type, holotypus, is relevé 2 in Table 2

Laserpitio peucedanoidis-Salicetum waldsteinianae var. geogr. Hypericum grisebachii T. Wraber in Dakskobler et Surina prov. (Hyperico grisebachiiSalicetum waldsteinianae T. Wraber in Dakskobler et Surina prov.)

Scabioso cinerei-Salicetum waldsteinianae Lakušić et al. 1979 ex Dakskobler et Surina ass. nov. = Salicetum waldsteinianae (Pawl. et Lakušić 1966) Lakušić et al. 1979 nom. inv., the nomenclature type, lectotypus hoc loco, is relevé 5 in Table 25 (Lakušić et al. 1979).

The association Salicetum waldsteinianae (Pawl. et Lakušić 1966) Lakušić et al. 1979 was invalidly published, violating the principles of ICPN (Weber et al. 2000) in several articles (e.g. Art. 5, 10, 15-18, 46). Rhododendro hirsuti-Salicetum appendiculatae Horvat ex Horvat, Glavač et Ellenberg 1974, nom. nov. prop., the nomenclature type, neotypus hoc loco, is relevé 18 in Table 4

- var. geogr. Paederota lutea

- var. geogr. Hypericum grisebachii

\section{Subalpine dwarf shrubs with dominating Rhododendron hirsutum and Rhodothamnus chamaecistus}

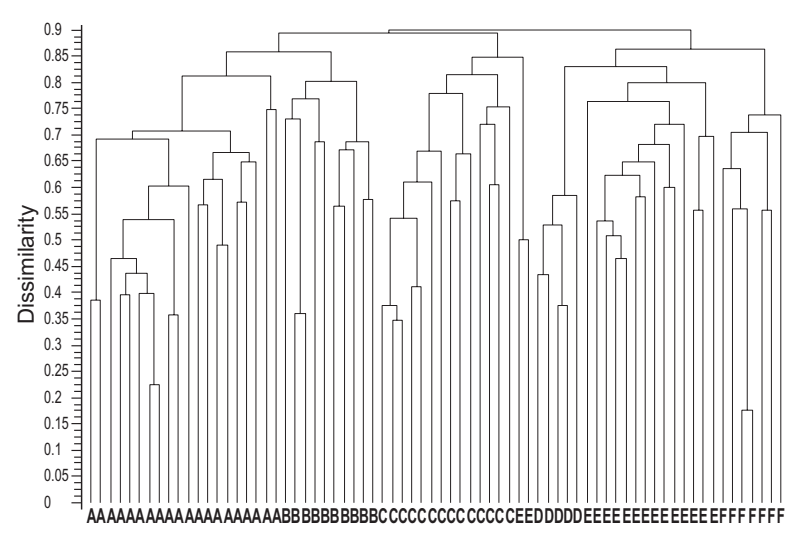

Figure 1: Dendrogram of relevés of montane-subalpine dwarf shrubs with dominant Rhododendron hirsutum and Salix spp. in the Julian Alps and the Trnovski Gozd Plateau (A - Dryado-Rhodothamnetum, B - Rhododendretum hirsuti vaccinietosum myrtilli, C - Laserpitio peucedanoidisSalicetum waldsteinianae, D - Heliospermo pusillae-Rhododendretum hirsuti, E - Rhododendro hirsuti-Salicetum appendiculatae, F - Homogyno sylvestris-Salicetum glabrae) - UPGMA, 1- similarity ratio.

Slika 1: Dendrogram popisov gorsko-subalpinskih grmišč s prevladujočimi vrstami Rhododendron hirsutum in Salix spp. (A - Dryado-Rhodothamnetum, B - Rhododendretum hirsuti vaccinietosum myrtilli, C - Laserpitio peucedanoidis-Salicetum waldsteinianae, D - Heliospermo pusillae-Rhododendretum hirsuti, E-Rhododendro hirsuti-Salicetum appendiculatae, F - Homogyno sylvestris-Salicetum glabrae) - UPGMA, komplement Wishartovega koeficienta podobnosti.

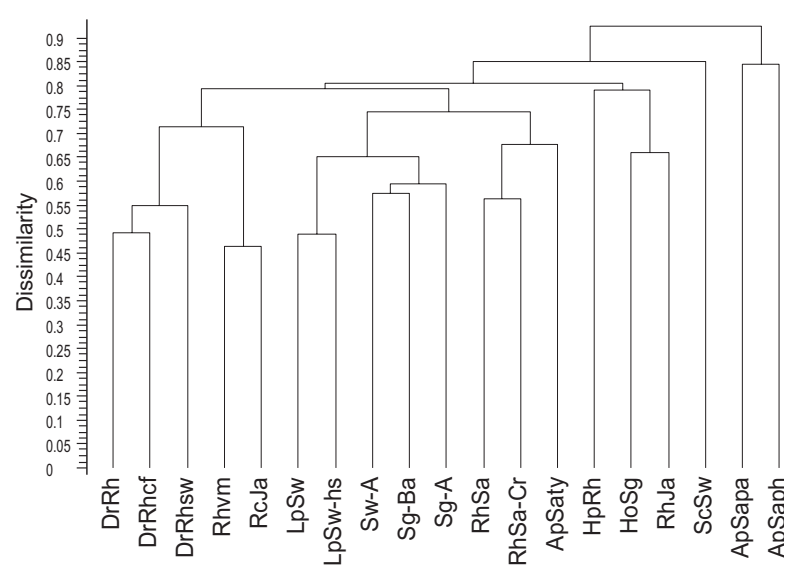

Figure 2: Dendrogram of syntaxa with dominant Rhododendron hirsutum, Salix spp. and (or) Juniperus alpina in the Alps and the Dinaric Alps (UPGMA, 1- similarity ratio).

Slika 2: Dendrogram sintaksonov s prevladujočimi vrstami $R$ hododendron hirsutum, Salix spp. in (ali) Juniperus alpina v Alpah in Dinarskem gorstvu (UPGMA, komplement Wishartovega koeficienta podobnosti). 


\section{Legend to Figure 2:}

DrRh Dryado-Rhodothamnetum chamaecisti, the Dolomites (E. Pignatti \& S. Pignatti, 2016, Association Table 11.3)

DrRhf Dryado-Rhodothamnetum chamaecisti caricetosum firmae, this article

DrRhsw Dryado-Rhodothamnetum chamaecisti salicetosum waldsteinianae, this article

Rhvm Rhododendretum hirsuti vaccinietosum myrtilli, this article

RcJa Rhodothamno chamaecisti-Juniperetum alpini (Poldini et al. 2004, Table 4)

LpSw Laserpitio peucedanoidis-Salicetum waldsteinianae, this article

LpSw-hs Salicetum waldsteinianae var. geogr. Homogyno sylvestris = Laserpitio peucedanoidis-Salicetum waldsteinianae, the Julian Alps, the Karavanke (Zupančič \& Žagar 2001, Table 1)

Sw-A Salicetum waldsteinianae, Austria (Karner 2007b, Table 10, Column 7)

Sg-Ba Salicetum glabrae, NE Alps (Eggensberger, 1994, Table 27, Columns 27-33)

Sg-A Salix glabra-community (prov.), Austria (Karner 2007b, Table 10, Column 8)

RhSa Rhododendro hirsuti-Salicetum appendiculatae, this article

RhSa-Cr Salicetum appendiculatae (=Rhododendro hirsuti-Salicetum appendiculatae), Croatia (Horvat et al., 1974, Table 135, Column 4)

ApSaty Aceri-Salicetum appendiculatae typicum, Austria (Karner 2007b, Table 10, Column 6)

$\mathrm{HpRh}$ Heliospermo pusillae-Rhododendretum hirsuti, this article

$\mathrm{HoSg}$ Homogyno sylvestris-Salicetum glabrae, this article

RhJa Rhododendro hirsuti-Juniperetum alpinae, the Dinaric Alps (Surina 2013, Table 2)

$\mathrm{ScSw}$ Scabioso cinerei-Salicetum waldsteinianae, Bosnia and Herzegovina (Lakušić et al. 1979, Table 25)

ApSapa Aceri-Salicetum appendiculatae petasitetosum albi, Austria (Karner 2007b, Table 10, Column 5)

ApSaph Aceri-Salicetum appendiculatae petasitetosum hybridi, Austria (Karner 2007b, Table 10, Column 4)

The relevés from the working table roughly grouped into three large clusters, the left additionally into two subclusters and the right into three (Figure 1). The first group of relevés comprises dwarf shrub stands with dominating Rhododendron hirsutum and Rhodothamnus chamaecistus, in places also Salix waldsteiniana. These relevés were arranged in Table 1.They grouped into a larger and a smaller cluster and those from the large cluster additionally into two subclusters. The stands in relevés from the larger cluster (relevés 1-20 in Table 1) occur on gentle to very steep $\left(5^{\circ}-40^{\circ}\right)$ shady stony slopes (northern, northwestern, northeastern, only in one relevé on a southeastern aspect), at elevations between 1,440 and $2,100 \mathrm{~m}$. They remain snow-covered for a large part of the year. The parent material is limestone, dolomite, even talus; the soil is initial, lithosol or shallow rendzina with moder humus. The composition by groups of diagnostic species is shown in Table 6, Columns 2 and 3. Species of subalpine-alpine grasslands from the class Elyno-Seslerietea occur alongside the dominating dwarf shrubs, Rhododendron hirsutum and Rhodothamnus chamaecistus. So far (Surina 2005a, Table 25), similar stands have been classified into the association Rhododendretum hirsuti Lüdi 1921, taking into account its description in Grabherr et al. (1993: 436-437). Our synthetic table (Table 5) comprises also the species composition of the association Dryado-Rhodothamnetum chamaecisti, which was described as new by Erika and Sandro Pignatti (2014: 455-457; 2016, Association Table 11.3, pages 319-320 and 428). Comparison of montane and subalpine-alpine shrub and hairy alpenrose communities from the Alps and the Dinaric Alps (Figure 2) showed that our relevés from the first, large cluster group with the relevés from the Dolomites and that their mutual similarity, despite certain different species distributed in a very limited area (endemics), is sufficient for us to classify them into the same association. The Pignattis classified it into the alliance Caricion firmae and identified it as a permanent stage without prospects for further succession. In terms of species composition its stands are connective with dwarf pine communities (Rhododendro hirsuti-Pinetum mugo, Rhodothamno-Pinetum mugo) at their lower range boundary and with subalpine-alpine grasslands from the alliances Caricion firmae and (or) Caricion austroalpinae at their upper range boundary. The only character species mentioned by Pignattis are Rhodothamnus chamaecistus and Dryas octopetala, although Rhododendron hirsutum occurs with equal frequency and mean coverage. They also listed two subunits, but did not typify or classify them into a hierarchical system. The relevés of the first subunit grow at higher elevations between 1,600 and $2,000 \mathrm{~m}$, and its differential species are from the order Seslerietalia: Sesleria caerulea, Carex firma, Aster bellidiastrum, Biscutella laevigata and Bartsia alpina. In the second group they listed relevés from the elevation of around 1,500 $\mathrm{m}$ which demonstrate higher species diversity and comprise several more acidophilous species of open coniferous forests. According to them, this subunit is characterised by Juniperus alpina, Homogyne alpina, 
Rubus saxatilis, Senecio abrotanifolius and Larix decidua. We determined the following diagnostic species for the association Dryado-Rhodothamnetum chamaecisti in the Julian Alps: Rhodothamnus chamaecistus, Rhododendron hirsutum, Selaginella selaginoides, Valeriana saxatilis, Dryas octopetala, Pedicularis rostratocapitata, Tofieldia calyculata, Homogyne discolor, Saxifraga aizoides, Pinguicula alpina and Salix retusa. These species are good indicators of environmental conditions - stony shady slopes in the subalpine and lower alpine belt with initial soils. Localities of the stands of the association DryadoRhodothamnetum in Slovenia are indicated in Figure 3.

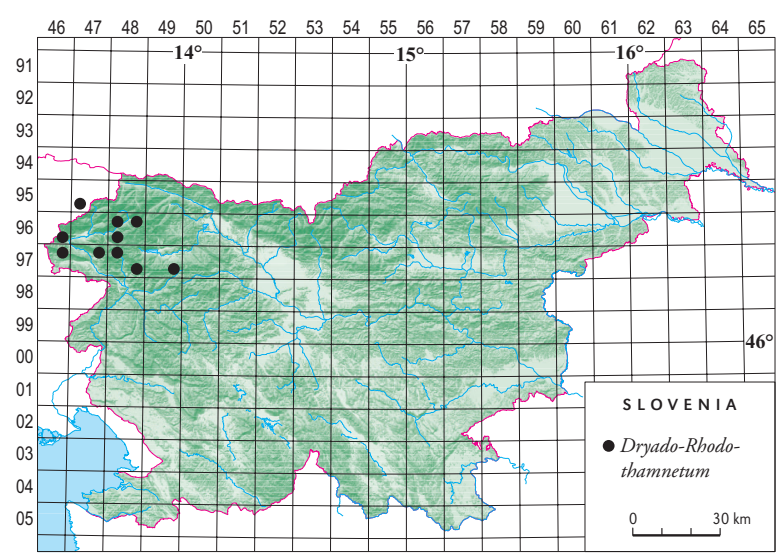

Figure 3: Localities of the stands of the association Dryado-Rhodothamnetum in Slovenia.

Slika 3: Nahajališča sestojev asociacije Dryado-Rhodothamnetum v Sloveniji.

We described two subassociations. The stands of the subassociation-caricetosum firmae (relevés 1 to $11 \mathrm{in} \mathrm{Ta-}$ ble 1) partly correspond to the first subunit mentioned by Erika and Sandro Pignatti (2014: 456). The differential species are Carex firma, Sesleria sphaerocephala and Phyteuma sieberi. The stands of this subassociation are the most similar to the original description of the association Dryado-Rhodothamnetum and demonstrate a similarity and contact with stony grasslands from the alliance Caricion firmae. Most of them were made at elevations above 1,800 $\mathrm{m}$. The second subassociation (relevés 12 to 20 in Table 1) was named -salicetosum waldsteinianae and its differential species are Salix waldsteiniana, Ranunculus carinthiacus, Anemone narcissiflora, Carex atrata and Viola biflora. They differentiate the group of relevés that partly resemble the second subunit mentioned by Erika and Sandro Pignatti (ibid.). They are distributed mainly in the subalpine belt (1,600 to $1,800 \mathrm{~m})$, on slightly deeper and acidified soils. Although they comprise a higher proportion of diagnostic species of classes Betulo-Alnetea, Mulgedio-Aconitetea and Vaccinio-Piceetea (Column 3 in Table 6), they are still dominated by species of the class Elyno-Seslerietea and their entire species composition still allows for them to be classified into the association Dryado-Rhodothamnetum, which is corroborated also by Figure 2 .

The group of relevés with dominating Rhododendron hirsutum in which Rhodothamnus chamaecistus occurs only sporadically and with low mean coverage (relevés 21 to 30 in Table 1), cannot be classified into this association (see also Figure 2). Salix waldsteiniana is particularly abundant in some of the relevés, although these stands did not group with the stands classified into its community. Species of classes Vaccinio-Piceetea, Betulo-Alnetea and Mulgedio-Aconitetea (Column 4 in Table 6) already dominate in terms of proportions. These relevés were made on steep shady slopes in the elevation belt spanning 1,600 to 2,000 m. Ecological conditions are similar to those in the previously described community, but soil conditions are different (deeper, most and acidified soil, moder rendzina) and allow for progressive development towards a willow community.

The entire species composition of these relevés, which are transitional between the relevés of the stands of association Dryado-Rhodothamnetum and relevés of the stands of association Salicetum waldsteinianae s. lat., indicates that they are the most similar to the stands of association Rhodothamno-Juniperetum alpini that was described by Poldini et al. (2004) for the Carnic Alps. Its diagnostic species are Juniperus alpina (J. sibirica), Rhododendron hirsutum, Sorbus chamaemespilus, Rhodothamnus chamaecistus, Vaccinium myrtillus, V. vitis-idaea and Homogyne alpina. They overgrow heavily karstified subalpine plateaus. All diagnostic species of this association occur also in the studied stands, but the species that gave the community its name, Juniperus alpina and Rhodothamnus chamaecistus, occur with a significantly lower frequency and substantially lower mean coverage. The question is whether our relevés, despite established floristic similarity, can be classified into the community named after Alpine (dwarf) juniper (Juniperus alpina) if this species does not have an edifying role in them. This role unquestionably belongs to Rhododendron hirsutum and (partly) Salix waldsteiniana. Ecological conditions are also slightly different. Our relevés occur on shady slopes, even talus and rarely on karstified plateaus. If we take into account the composition of the upper stand layer we should, for now, opt for classification into the association Rhododendretum hirsuti (as described by Grabherr et al. 1993), new subassociation -vaccinietosum myrtilli. Its differential species are Vaccinium myrtillus, Luzula sylvatica, Salix waldsteiniana, Rosa pendulina, Sorbus chamaemespilus, Campanula scheuchzeri, Viola biflora and Festuca nigrescens. We also differentiate the variant with Empetrum hermaphroditum 
(its differential species include the taxon Rhododendron $\times$ intermedium) on promontories or ridges with raw humus. Localities of the stands of the subassociation Rhododendretum hirsuti vaccinietosum myrtilli in Slovenia are indicated in Figure 4.

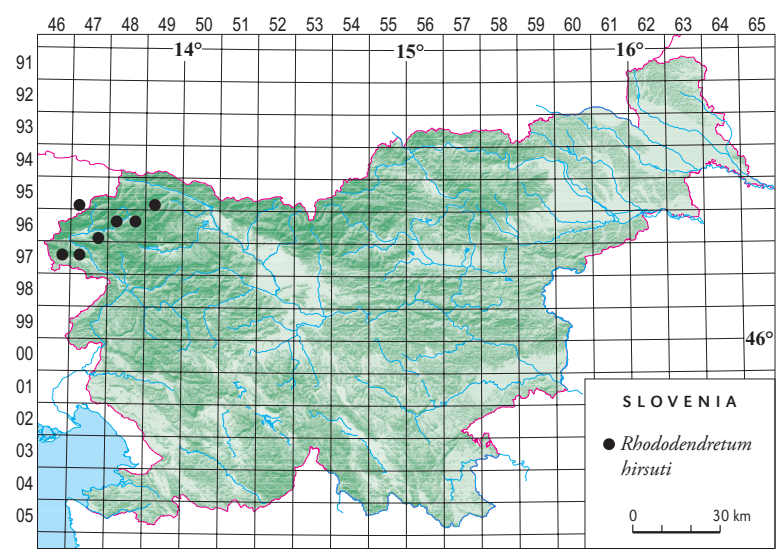

Figure 4: Localities of the stands of the subassociation Rhododendretum hirsuti vaccinietosum myrtilli in Slovenia.

Slika 4: Nahajališča sestojev sintaksona Rhododendretum hirsuti vaccinietosum myrtilli v Sloveniji.

\section{Ass. Salicetum waldsteinianae s. lat. in the Slovenian Alps and the Snežnik Mts.}

Most of the relevés in the central relevé cluster in the initial working table (Figure 1) are classified into the association Salicetum waldsteinianae s. lat. They demonstrate a similarity with two of our relevés in which, however, the uppermost stand layer is dominated by Salix appendiculata, so they are classified into the association Rhododendro hirsuti-Salicetum appendiculatae (Chapter 3.6). So far, the relevés of the association Salicetum waldsteinianae in the Slovenian Alps have been published by T. Wraber (1980), Zupančič \& Žagar (2001) and Surina (2005a, Table 28). These authors classified them into the geographical variant Salicetum waldsteinianae var. geogr. Homogyne sylvestris, which was determined in detail by Zupančič \& Žagar (ibid.). Despite similarities in their sites the relevés from the Southeastern Alps comprise numerous species that are absent from the stands of this association elsewhere in the Alps (in Austria, northern Italy). Waldstein willow stands in the Slovenian Alps are syndynamically related with stands of the association Saxifrago aizoidis-Caricetum ferrugineae, which might be a southeastern-Alpine form of the "macroassociation" Caricetum ferruginae s. lat., so it is reasonable to change the current rank of the geographical variant Homogyne sylvestris to the rank of a new asso- ciation. This is supported also by the comparison whose results are shown in Figure 2. Table 2 comprises 14 relevés of this association from the Julian Alps. Diagnostic species of the new association are Salix waldsteiniana, Laserpitium peucedanoides, Carex ferruginea, Astrantia bavarica, Salix glabra, Rhodiola rosea, Selaginella selaginoides, Aconitum angustifolium, Homogyne sylvestris, Rhodothamnus chamaecistus, Pulsatilla alpina subsp. austroalpina and Hedysarum hedysaroides. In terms of ecology the listed species characterise the new association both as a shrub community on shady stony slopes in the subalpine belt (between 1,300 and 1,900 $\mathrm{m}$ a.s.l.) with a persistent snow cover and as a southeastern-Alpine community. We named it Laserpitio peucedanoidis-Salicetum waldsteinianae, after a frequent species of subalpine grasslands and open altimontanesubalpine forests of this area, Laserpitium peucedanoides. We distinguish between two subassociations. Relevés 1 to 5 in Table 2 are classified into the subassociation -saxifragetosum rotundifoliae. Its differential species are Saxifraga rotundifolia, Primula elatior, Poa alpina and Phleum rhaeticum. They characterise a mesophilous, mature form of the studied community on fresh rendzinas. For now, we group the other relevés into two variants within the typical subassociation (-typicum). The variant with Sorbus chamaemespilus indicates mixed shrub communities with sporadic occurrence of Alnus viridis that demonstrate a certain similarity with the stands of the association Rhododendro hirsuti-Alnetum viridis. The stands of the variant with Hedysarum hedysaroides indicate the initial form of the studied community on very shallow soils and are syndynamically related to the stands of the association Saxifrago aizoidis-Caricetum ferrugineae. Localities of the stands of the association Laserpitio peucedanoidis-Salicetum waldsteinianae in Slovenia are indicated in Figure 5.

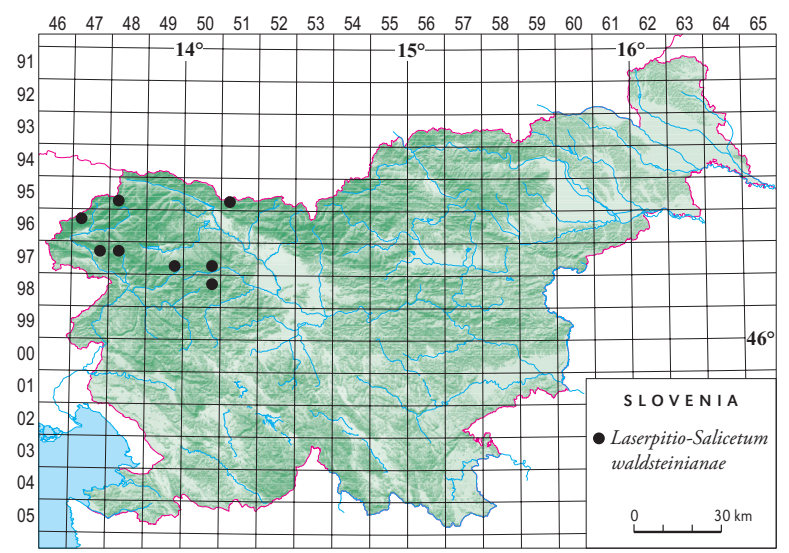

Figure 5: Localities of the stands of the association Laserpitio-Salicetum waldsteinianae in northwestern Slovenia.

Slika 5: Nahajališča sestojev asociacije Laserpitio-Salicetum waldsteinianae v severozahodni Sloveniji. 
Stands of the association Salicetum waldsteinianae s. lat. were studied on Mt. Snežnik (NW Dinaric Alps, Liburnian Karst) as well, namely by late Tone Wraber (1997, 2000) who, unfortunately, passed away before he published the relevés. In his manuscript, which is kept in Wraber's library at the Botanical Garden of the University of Ljubljana, we found four relevés arranged herein in Table 3. Comparative analyses of similarities (Sørensen's similarity index, 1948) between stands from the Julian Alps (relevés in Table 2) and Mt. Snežnik demonstrated a similarity of $40 \%$ (and a 36\% similarity for the relevés from Table 2 and additional ones published by Zupančič and Žagar, 2001), which did not justify the classification of the stands from Mt. Snežnik into the association Laserpitio-Salicetum waldsteinianae. The ecology of the stands from Mt. Snežnik is somewhat different, and this is reflected in their species composition: they host a significantly lower number of species from subalpine-alpine grasslands and they are frequently syndynamically related with the stands from the associations Hyperico grisebachii-Caricetum ferrugineae, Doronico austriaci-Adenostyletum alliariae (Surina 2005b) and Hyperico grisebachii-Pinetum mugo (Zupančič et al. 2004). Hypericum richeri subsp. grisebachii appeared to be a good differential species for the stands from Mt. Snežnik. On the other hand, 61 out of 66 species recorded in the stands dominated by Salix waldsteiniana from Mt. Snežnik (Wraber, mscr.) occur in stands of the association Laserpitio-Salicetum waldsteinianae in the South-Eastern Alps as well (Appendix 1). The stands from Mt. Snežnik can therefore provisionally be classified either into the new geographical variant Laserpitio peucedanoidis-Salicetum waldsteinianae var. geogr. Hypericum grisebachii or into the new association Hyperico grisebachii-Salicetum waldsteinianae. However, we would need more relevés for a proper description and typification of the new association.

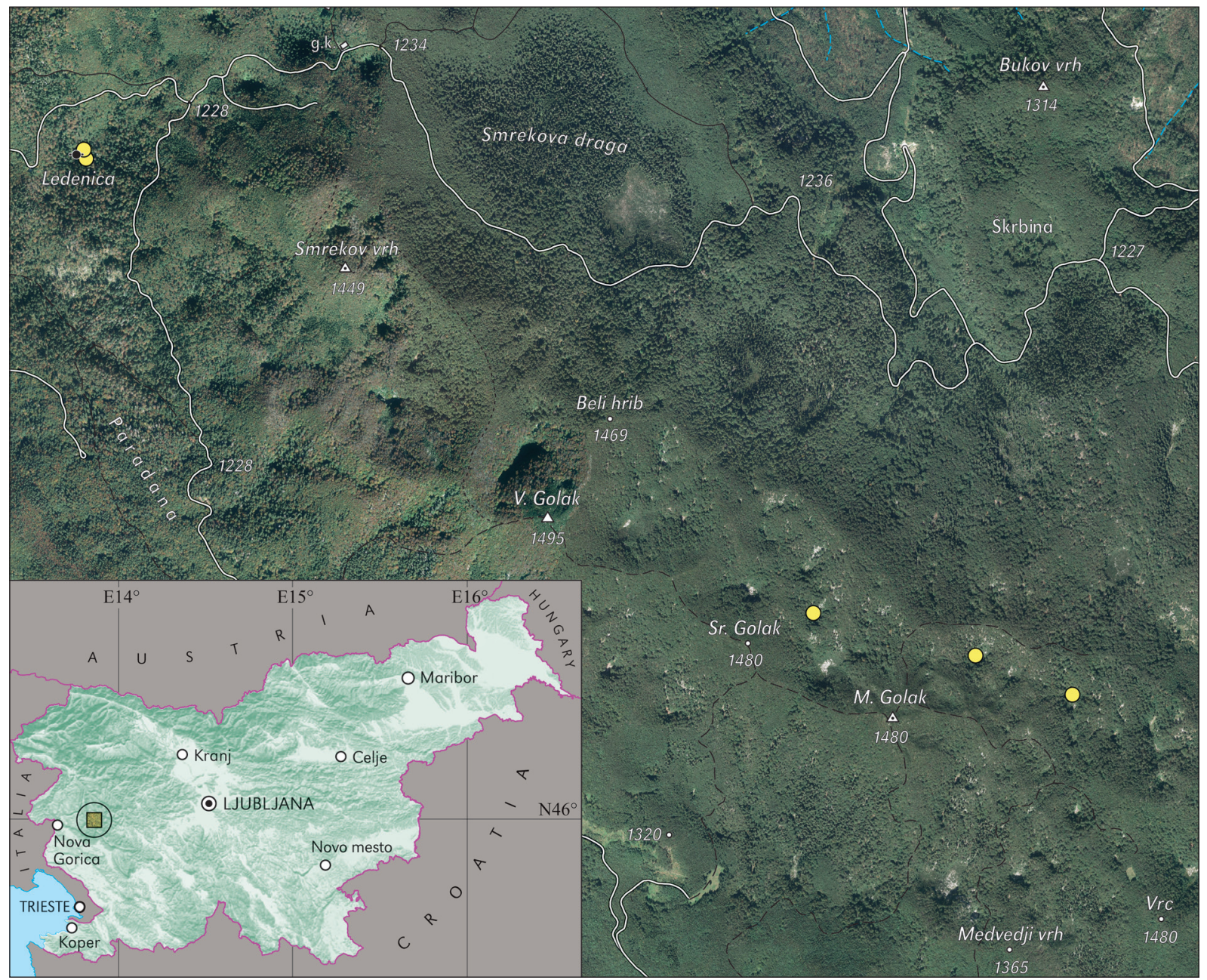

Figure 6: Localities of stands of the association Heliospermo pusillae-Rhododendretum hirsuti on the Trnovski Gozd Plateau. Slika 6: Nahajališča sestojev asociacije Heliospermo-Rhododendretum hirsuti v Trnovskem gozdu. 


\section{Association Heliospermo pusillae- Rhododendretum hirsuti on the Trnovski Gozd Plateau}

In our comparison of all relevés (Figure 1) the first five relevés in Table 4 grouped separately from the relevés of other determined communities and are therefore classified into a new association Heliospermo pusillaeRhododendretum hirsuti. Stands of the new association are characterised by dominating Salix waldsteiniana and Rhododendron hirsutum in the shrub layer, but comprise also Salix glabra, S. appendiculata and Rhodothamnus chamaecistus. They occur in rocky frost hollows on the Trnovski Gozd Plateau at elevantions between 1,100 and 1,400 m (Paradana, Kraljeva Kamra, under Srednji and Veliki Golak - Figure 6), where the snow cover, and consequently also very cold air among the rockfall material, persists long into the summer. Stands of the new association are therefore characterised primarily by hygrophilous and frigophilous species characteristic for such rocky sites: Heliosperma pusillum (its community Drepanoclado uncinati-Heliospermetum pusillae has developed on even more extreme parts of some of these hollows - Surina \& Vreš 2004), Carex capillaris, C. atrata, Salix retusa, in part also Paederota lutea, Viola biflora, Salix serpyllifolia, Valeriana saxatilis, on one of the relevés also the endemic Primula carniolica, as well as by an abundant moss layer dominated by Sanionia uncinata, syn. Drepanocladus uncinatus). Until now such species combination has not been recorded anywhere else in the Slovenian mountains, not even in the Julian Alps or Snežnik Mountains, even though Waldstein willow and hairy alpenrose stands also occur there. In some spots the stands of the new association are at the contract with dwarf pine stands (Rhodothamno-Pinetum mugo), with the stands of larged-leaved willow (Rhododendro hirsutiSalicetum appendiculatae) and with the stands of the association Drepanoclado uncinati-Heliospermetum pusillae. Their full species composition indicates a certain similarity with the stands dominated by glabrous willow (Salix glabra) that will be described below and with the stands of the association Rhododendro hirsuti-Juniperetum alpinae (Surina 2013), also from the Dinaric Alps. In terms of the structure of phytosociological groups (Column 14 in Table 6) the association is distinctly transitional between the communities of the alliance Alnion viridis and the communities of the alliance Ericion carneae and order Rhododendro hirsuti-Ericetalia carneae. For now we find the classification into this order and class Rhododendro hirsuti-Ericetea carneae (Mucina et al. 2016) more appropriate.

\section{Association Homogyno sy/vestris- Salicetum glabrae in the southern Julian Alps and on the Trnovski Gozd Plateau}

The group of seven relevés with dominant Salix glabra from the Julian Alps and the northern part of the Trnovski Gozd Plateau (relevés 6-12 in Table 4) clustered in the right side of the dendrogram with all relevés (Figure 1). With their entire species composition these stands show a certain similarity with the stands of associations Heliospermo-Rhododendretum hirsuti and Rhododendro hirsuti-Juniperetum alpinae (Figure 2), but their structure is unique. The upper stand layer is dominated by Salix glabra and Rhododendron hirsutum, in certain places accompanied by Salix appendiculata. Salix waldsteiniana and Juniperus alpina, however, were not recorded there. These stands therefore cannot be classified into the above-mentioned or described syntaxa. They clearly differentiate also from the glabrous willow community from the Northeastern Alps that Eggensberger (1994) described as the association Salicetum glabrae. Mutual comparison of the floristic composition of our relevés with his, despite several other species that they have in common (such as Rhododendron hirsutum, Calamagrostis varia, Adenostyles glabra, Betonica alopecuros) demonstrates a merely $32 \%$ floristic similarity (Sørensen 1948), which does not allow for classification into the same association. Eggensberger (ibid.) classifies the association Salicetum glabrae into the alliance Salicion waldsteinianae Oberdorfer 1978 (which is a synonym for the alliance Alnion viridis). Karner (2007a,b) treats the stands with Salix glabra in Austria as the Salix glabra community (prov.) and considers it a special form of the association Salicetum waldsteinianae. His observation is confirmed also by hierarchical classification as both (north)eastern-Alpine glabrous willow communities bond with the association Salicetum waldsteinianae and not with the studied south-eastern Alpine-Dinaric community (Figure 2). Our community occurs still in the belt of montane-altimontane beech forests at the elevations between 950 and 1,400 m, on steep to very steep shady slopes, in gravelly gullies, in erosion-exposed areas under rock faces and barriers, on rockfall material. It therefore represents a pioneer or succession stage where the natural conditions (annual snowslides, shallow, unstable soils) do not allow for the development of beech forests and is classified into a new association Homogyno sylvestris-Salicetum glabrae. Its diagnostic species are Salix glabra, Rhododendron hirsutum, Calamagrostis varia, Sesleria caerulea, Homogyne sylvestris, Carex ferruginea, Ostrya carpinifolia, Astrantia carniolica, Betonica alopecurus, Knautia drymeia 
and Cyclamen purpurascens. Co-occurrence of the listed species indicates gravelly dolomite parent material, initial soil, shady and relatively moist sites, a pioneer stage of development in the belt of Illyrian beech forests (mainly from the association Rhododendro hirsuti-Fagetum). Composition by groups of diagnostic species (Column 15 in Table 6) allows for the classification of the new association into the alliance Ericion carneae, order RhododendroEricetalia carneae and class Rhododendro hirsuti-Ericetea carneae. Localities of the stands of the new association on the map of Slovenia are indicated in Figure 7.

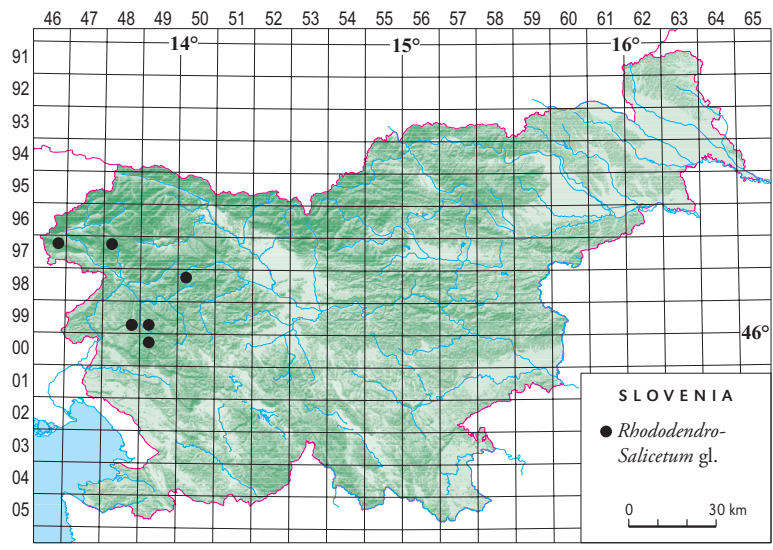

Figure 7: Localities of the stands of the association Homogyno sylvestrisSalicetum glabrae in Slovenia.

Slika 7: Nahajališča sestojev asociacije Homogyno sylvestris-Salicetum glabrae v Sloveniji.

\section{Association Rhododendro hirsuti- Salicetum appendiculatae in the Julian Alps and on the Trnovski Gozd Plateau}

Classification of our relevés shows the stands with dominating Salix appendiculata grouping within the third group (on the right) (Figure 1). We arranged them in Table 4 (relevés 13-28). By comparing these relevés with similar communities in the Alps and in the Dinaric Alps (Figure 2, Table 5) we determined that they resemble the relevés of the association Salicetum appendiculatae (Horvat et al. 1974) and relevés of the subassociation Aceri-Salicetum appendiculatae typicum (Karner 2007b). Horvat (1962: 105 ) used the name Salicetum grandiflorae Horv. ass. nova for the large-leaved willow community that overgrows the edges of karst sinkholes and depressions in the mountains of southwestern Croatia (Liburnian Karst), where snow persists for extended periods. In his short description of the new association (without a phytosociological table) he listed the taxon Senecio crassifolius as a character species
(Horvat may have recorded Senecio ovatus (syn. S. fuchsii); species $S$. crassifolius (syn. Senecio leucanthemifolius) does not occur in Croatia) and a list of more frequent species, including Homogyne sylvestris, Juniperus alpina, Hypericum richeri subsp. grisebachii, Clematis alpina, Lonicera caerulea s. lat. (see also Trinajstić 2008: 123). Horvat et al. (1974, Table 135, Column 4) published a synthetic table of the association Salicetum appendiculatae Horvat 1962 based on 10 relevés from Gorski Kotar in Croatia, which is (as it was published before 1979) a valid description of the new association (Weber et al. 2000). It is true that literature sources, including more recent ones (e.g. E. Pignatti \& S. Pignatti 2014: 235) mention the same name with a different author for a different community from the Alps (Salicetum appendiculatae Oberd. 1957). The original name of Oberdorfer's community was Acero-Salicetum appendiculatae (Oberdorfer 1957) and the quotation Salicetum appendiculatae (Br.-Bl. 50) Oberd. $1957 \mathrm{em}$. is from the second edition (Oberdorfer 1978). A slightly corrected original name Aceri-Salicetum appendiculatae Oberdorfer 1957 is therefore the valid name (Karner 2007a, b). In phytosociological investigations of the Snežnik Mts. Gabrijel Tomažič observed and recorded also a community at the bottom of deep sinkholes and frost hollows which he called Rhodoro-Salicetum grandiflorae, but his relevés were never published (Tomažič \& Tregubov 1958, 1959, Zupančič 2001, Surina 2013). Our comparison shows that Salicetum appendiculatae Horvat is not a synonym for the association Aceri-Salicetum appendiculatae Oberdorfer (Acer pseudoplatanus and several other species listed in Oberdorfer's original relevé of this association from 1957 are completely absent in Horvat's synthetic table from 1974). These are obviously two different communities, where the stands that Karner (ibid.) classified into the subassociation Aceri-Salicetum appendiculatae typicum could in fact be part of Horvat's community which they resemble more than the stands of two other subassociations of the association Aceri-Salicetum (-petasitetosum albi and -petasitetosum hybridi). Because Horvat's name Salicetum appendiculatae is frequently used with different authors as the name of another syntaxon and is therefore potentially misleading, nomen ambiguum (Weber et al. 2000, Art. 36), we propose a new name that was first used (before Horvat) by G. Tomažič: Rhododendro hirsuti-Salicetum appendiculatae, but the author cited for the association is still Horvat. Based on our comparisons we differentiate two geographical variants, var. geogr. Paederota lutea (Julian Alps, Trnovski Gozd Plateau) and var. geogr. Hypericum grisebachii (Liburnian Karst: Snežnik Mts., Gorski Kotar). This article describes only the stands of the geographical variant Paederota lutea that were found in the western and southern part of the Ju- 


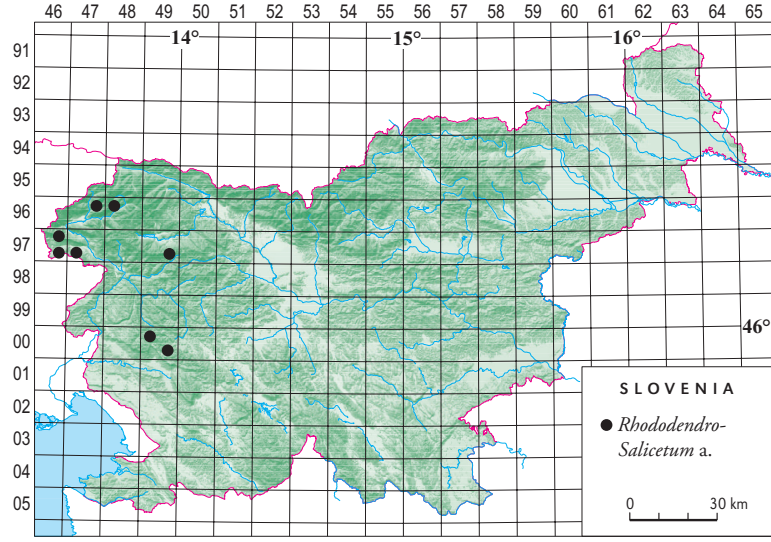

Figure 8: Localities of the stands of the association Rhododendro hirsuti-Salicetum appendiculatae in western Slovenia and northeastern Italy. Slika 8: Nahajališča preučenih sestojev asociacije Rhododendro hirsuti-Salicetum appendiculatae v zahodni Sloveniji in severovzhodni Italiji.

lian Alps with their foothills and on the Trnovski Gozd Plateau (Figure 8). The relevés were made on elevations between 470 and $1,650 \mathrm{~m}$, in stony frost hollows and shady gullies with initial soils (lithosol, moder rendzina) and a persistent snow cover. Such hollows covered with rockfall material can be found in Pradol, a dry ravine between Mts. Mija and Ljubija at the border between Slovenia and Italy, in the territory of the Republic Italy, at the elevation of only $470 \mathrm{~m}$. This is where we described a new variant with Dryopteris remota (its differential species are also Polypodium vulgare and Phyllitis scolopendrium). The stands of the new variant are surrounded by stands of European ash and sycamore maple communities (Veratro nigri-Fraxinetum, Lamio orvalae-Aceretum) where these hygrophilous ferns frequently occur. Similar shady hollows covered by rockfall or talus deposits are located under Mt. Matajur (Glava), in cirque Dol under the ridge of Breginjski Stol, under Mt. Črna Gora at Mt. Črna Prst, and on the Trnovski Gozd Plateau at the rim of the karst cave in Paradana, in the ravines under the peaks of Mali Golak and Veliki Golak (Kraljeva Kamra), and under the peak Vrh Hoje, where we found stands of the typical variant. Slightly different in terms of floristic composition are large-leaved willow stands in shady stony gullies above the Bala valley in the central Julian Alps, where we described the variant with Peucedanum ostruthium. In addition to Salix appendiculata these shrub communities generally comprise, in the upper shrub, occasionally also in the lower tree layer, individual specimens of Sorbus aucuparia, Acer pseudoplatanus, Picea abies, Abies alba, rarely also Alnus viridis and Pinus mugo. Only Sorbus aucuparia is frequent and has larger coverage than other above-listed species. The species that dominate in the lower shrub layer are Rhododendron hirsutum, Rubus idaeus and Lonicera caerulea, in places also single specimens of Salix glabra, $S$. waldsteiniana, Juniperus alpina, Lonicera nigra and Ribes alpinum. Composition by groups of diagnostic species is in Column 11 in Table 6. The large-leaved willow community is a long term succession stage on sites where natural factors prevent the development of forest and has a similar protective role as green alder stands.

\section{Conclusions}

Steep, shady, stony and gravelly slopes and hollows with a persistent snow cover left by the snowslides that descend these slopes every year are extreme sites for forest growth. Although dwarf pine (Rhodothamno-Pinetum mugo) and partly also green alder stands (Rhododendro hirsuti-Alnetum viridis) represent the predominant shrub community types on such extreme sites under and at the existing timberline in the Julian Alps and on the Trnovski Gozd Plateau, other stands whose top layer is dominated by willows Salix appendiculata, S. waldsteiniana and (or) S. glabra also occur on smaller areas. We described their communities, which are usually long-term successional stages, accompanied by individual Sorbus aucuparia, Picea abies or Acer pseudoplatanus trees. Similar communities are known also elsewhere in the Eastern Calcareous Alps and in the Dinaric Alps. Nevertheless, floristic differences between them can be significant and naming them after only one species (Salicetum appendiculatae, Salicetum waldsteinianae, Salicetum glabrae) is not very appropriate and can even be misleading. We therefore described two new associations, Laserpitio peucedanoidis-Salicetum waldsteinianae and Homogyno sylvestris-Salicetum glabrae. As for the large-leaved willow community in the Southeastern and the Dinaric Alps, which was first recorded in Slovenia by Gabrijel Tomažič and its description first published by Ivo Horvat, we propose a new name - Rhododendro hirsuti-Salicetum appendiculatae. Among the listed willows Salix waldsteniana is syndynamically related also to low shrub communities above the upper timberline up to the alpine belt where hairy alpenrose (Rhododendron hirsutum) is the dominant species. These shrub communities also overgrow shady slopes and stony soils, sometimes as contact communities with Carex ferruginea dominating grasslands. Despite some common diagnostic species (Rhododendron hirsutum, Rhodothamnus chamaecistus) they are floristically and ecologically slightly different from the communities with dominating Alpine juniper (Juniperus alpina) and cannot be classified within its associations (Rhodothamno-Juniperetum alpini, Rhododendro hirsuti-Juniperetum alpinae) or within dwarf pine communities. Some of these dwarf shrubs are tenta- 
tively treated as a syntaxon Rhododendretum hirsuti vaccinietosum myrtilli. We have established the occurrence of the stands of the association Dryado-Rhodothamnetum chamaecisti that was recently described in the Dolomites also in the Julian Alps and described a new association Heliospermo pusillae-Rhododendretum hirsuti on the Trnovski Gozd Plateau.

All shrub communities described herein have an important protective and biotope role and are also the site of two species of European conservation concern (Čušin et al. 2004): Eryngium alpinum (which occurs in stands of the association Laserpitio-Salicetum waldstenianae) and Primula carniolica (in stands of associations Rhododendro hirsuti-Salicetum appendiculatae and Heliospermo pusillae-Rhododendretum hirsuti), some species protected in Slovenia (Anon. 2004): Huperzia selago, Lycopodium annotinum, Cyclamen purpurascens, Leontopodium alpinum, Gentiana lutea subsp. symphyandra, G. clusii, $G$. pannonica, Helleborus niger, Dactylorhiza fuchsii, Coeloglossum viride, Gymnadenia conopsea, Malaxis monophyllos, Nigritella rhellicani, N. miniata s. lat., Primula auricula and Pinguicula alpina, and some endemic or rare species (Dakskobler et al. 2016): Aconitum angustifolium, Centaurea julica subsp. haynaldii, Geranium argenteum, Hieracium prenanthoides.

\section{Povzetek}

\section{Fitocenološka analiza montansko- subalpinskih vrbovih grmišč v Julijskih Alpah in Trnovskem gozdu (severozahodna in zahodna Slovenija)}

Strma osojna kamnita in gruščnata pobočja in kotanje, kjer ali kamor vsako leto polzijo snežni plazovi in se sneg v njih dolgo zadržuje, so skrajna rastišča za uspevanje gozda. Čeprav sta prevladujoča tipa grmiščnega rastja na takih skrajnih rastiščih pod in na zdajšnji gozdni meji v Julijskih Alpah in v Trnovskem gozdu predvsem ruševje (Rhodothamno-Pinetum mugo) in deloma zelenojelševje (Rhododendro hirsuti-Alnetum viridis), na manjših površinah uspevajo tudi sestoji, kjer $\mathrm{v}$ najvišji sestojni plasti prevladujejo vrbe: Salix appendiculata, S. waldsteiniana, S. glabra. Opisali smo njihove združbe, ki so dolgotrajni sukcesijski stadiji, v katerih se med drevesnimi vrstami posamično pojavljajo predvsem jerebika (Sorbus aucuparia), le ponekod tudi smreka in gorski javor. Podobne združbe poznamo tudi drugod $\mathrm{v}$ karbonatnih Vzhodnih Alpah in v Dinarskem gorstvu. Ker so floristične razlike med njimi lahko precejšnje, je njihovo poimenovanje zgolj po eni vrsti (Salicetum appendicula- tae, Salicetum waldsteinianae, Salicetum glabrae) manj primerno, lahko celo zavajajoče. Zato smo opisali novi asociaciji Laserpitio peucedanoidis-Salicetum waldsteinianae in Homogyno sylvestris-Salicetum glabrae. Za združbo velikolistne vrbe v Jugovzhodnih Alpah in Dinarskem gorstvu, ki jo je v Sloveniji prvi popisal Gabrijel Tomažič, njen opis pa prvi objavil Ivo Horvat, predlagamo novo ime Rhododendro hirsuti-Salicetum appendiculatae. Med tremi naštetimi vrbami je vrsta Salix waldsteniana sindinamsko povezana tudi z nizkimi grmišči nad zgornjo gozdno mejo vse do alpinskega pasu, v katerih prevladuje dlakavi sleč (Rhododendron hirsutum). Tudi ta grmišča poraščajo osojna pobočja in kamnita tla, ponekod so stična s travišči rjastorjavega šaša (Carex ferruginea). Kljub skupnim diagnostičnim vrstam (Rhododendron hirsutum, Rhodothamnus chamaecistus) so floristično in ekološko nekoliko drugačna od združb s prevladujočim sibirskim brinom (Juniperus alpina) in jih ne moremo uvrščati $\mathrm{v}$ njegovi asociaciji (Rhodothamno-Juniperetum alpini, Rhododendro hirsuti-Juniperetum alpinae), prav tako ne $\mathrm{v}$ ruševje. Nekatera od teh pritlikavih grmišč za zdaj obravnavamo v sintaksonu Rhododendretum hirsuti vaccinietosum myrtilli. Ugotavljamo pojavljanje sestojev asociacije Dryado-Rhodothamnetum chamaecisti, ki je bila nedavno opisana v Dolomitih, tudi v Julijskih Alpah in opisujemo novo asociacijo Heliospermo pusillae-Rhododendretum hirsuti v Trnovskem gozdu.

Vse v članku opisane grmiščne združbe imajo pomembno varovalno in biotopsko vlogo in so tudi življenjski prostor dveh evropsko varstveno pomembnih vrst (Čušin et al. 2004): Eryngium alpinum (raste v sestojih asociacije Laserpitio-Salicetum waldstenianae) in Primula carniolica (raste v sestojih asociacij Rhododendro hirsuti-Salicetum appendiculatae in Heliospermo pusillae-Rhododendretum hirsuti), nekaterih v Sloveniji zavarovanih vrst (Anon. 2004): Huperzia selago, Lycopodium annotinum, Cyclamen purpurascens, Leontopodium alpinum, Gentiana lutea subsp. symphyandra, G. clusii, G. pannonica, Helleborus niger, Dactylorhiza fuchsii, Coeloglossum viride, Gymnadenia conopsea, Malaxis monophyllos, Nigritella rhellicani, N. miniata s. lat., Primula auricula in Pinguicula alpina ter nekaterih endemitov ali redkih vrst (Dakskobler et al. 2016): Aconitum angustifolium, Centaurea julica subsp. haynaldii, Geranium argenteum, Hieracium prenanthoides.

\section{Acknowledgements}

We would like to thank the heirs of the late Tone Wraber for giving his manuscripts and professional literature to the safekeeping of the Botanical Garden of the University of Ljubljana, and to its director, Dr. Jože Bavcon, who 
allowed us to examine professor's legacy. Mag. Andrej Seliškar and Doc. Dr. Andrej Rozman assisted us in the processing of relevés. Iztok Sajko prepared all Figures for print. Anonymous reviewer helped us with valuable improvements and corrections. The authors acknowledge the financial support from the Slovenian Research Agency (research core funding No. P1-0236). English translation by Andreja Šalamon Verbič.

\section{References}

Aeschimann, D., Lauber, K., Moser, D. M. \& Theurillat, J.-P. 2004a: Flora alpina. Bd. 1: Lycopodiaceae-Apiaceae. Haupt Verlag, Bern, Stuttgart, Wien, $1159 \mathrm{pp}$.

Aeschimann, D., Lauber, K., Moser, D. M. \& Theurillat, J.-P. 2004b: Flora alpina. Bd. 2: Gentianaceae-Orchidaceae. Haupt Verlag, Bern, Stuttgart, Wien, 1188 pp.

Aeschimann, D., Lauber, K., Moser, D. M. \& Theurillat, J.-P. 2004c: Flora alpina. Bd. 3: Register. Haupt Verlag, Bern, Stuttgart, Wien, $322 \mathrm{pp}$.

Anonymous 2004: Uredba o zavarovanih prosto živečih rastlinskih vrstah. Uradni list RS 46/2004.

Braun-Blanquet, J. 1964: Pflanzensoziologie. Grundzüge der Vegetationskunde. 3. Auflage. Springer, Wien - New York, 865 pp.

Buser, S. 2009: Geološka karta Slovenije 1: 250.000. Geological map of Slovenia 1: 250,000. Geološki zavod Slovenije, Ljubljana.

Cegnar T. 1998: Temperatura zraka. In: Fridl, J., Kladnik, D., Orožen Adamič, M. \& Perko, D. (eds.): Geografski atlas Slovenije. Država v prostoru in času. Državna založba Slovenije, Ljubljana, pp. 100-101.

Čušin, B., Babij, V., Bačič, T., Dakskobler, I., Frajman, B., Jogan, N., Kaligarič, M., Praprotnik, N., Seliškar, A., Skoberne, P., Surina, B., Škornik, S. \& Vreš, B. 2004: Natura 2000 v Sloveniji, Rastline. Založba ZRC, ZRC SAZU, Ljubljana. 172 pp.

Dakskobler, I. 2016: Two new pioneer communities of Sorbus aucuparia and Sorbus aria in the southern Julian Alps. Hacquetia 15 (1): 67-91.

Dakskobler, I., Rozman, A. \& Seliškar, A. 2013a: Forest and scrub communities with green alder (Alnus viridis) in Slovenia. Hacquetia 12 (2): $95-185$.

Dakskobler, I., Franz, W. R. \& Rozman, A. 2013b: Phytosociology and ecology of Rhamnus fallax in the Southeastern Alps and in the northern part of the Dinaric Alps. Wulfenia 20: 101-144.

Dakskobler, I., Kutnar, L. \& Rozman, A. 2016: Macesnovje, ruševje, zelenojelševje in druge gorske grmovne združbe v Sloveniji. Silva Slovenica, Gozdarski inštitut Slovenije, 156 pp.

Eggensberger, P. 1994: Die Pflanzengesellschaften der subalpinen umd alpinen Stufe der Ammergauer Alpen und ihre Stellung in den Ostalpen. Ber. Bayer. Bot. Ges., Beihefte 8: 3-239.

Grabherr, G., Greimler, J. \& Mucina, L. 1993: Seslerietea albicantis. In: Grabherr, G. \& Mucina L. (eds.): Die Pflanzengesellschaften Österreichs. Teil II: Natürliche waldfreie Vegetation, Gustav Fischer Verlag, Jena - Stuttgart - New York, pp. 402-446
Horvat, I. 1962: Vegetacija planina Zapadne Hrvatske sa 4 karte biljnih zajednica sekcije Sušak. Acta biologica 2, Prirodoslovna istraživanja 30, JAZU Zagreb, 179 pp.

Horvat, I., Glavač, V., Ellenberg H. 1974: Vegetation Südosteuropas. Gustav Fischer, Stuttgart, 768 pp.

Karner, P. 2007a: Betulo-Alnetea viridis prov. In: Willner, W. \& Grabherr, G. (eds.): Die Wälder und Gebüsche Österreichs. Ein Bestimmungswerk mit Tabellen. 1. Textband. Spektrum Akademischer Verlag in Elsevier, Heidelberg, pp. 83-88.

Karner, P. 2007b: Betulo-Alnetea viridis prov. In: Willner, W. \& Grabherr, G. (eds.): Die Wälder und Gebüsche Österreichs. Ein Bestimmungswerk mit Tabellen. 2. Tebellenband. Spektrum Akademischer Verlag in Elsevier, Heidelberg, pp. 47-52.

Lakušić, R., Pavlović, D., Abadžić, S., Kutleša, Lj., Mišić Lj., Redžić, S., Maljević, D. \& Bratović, S. 1979: Struktura i dinamika ekosistema planine Vranice u Bosni. In Rauš, Dj. (ed): Drugi kongres ekologa Jugoslavije, Zagreb, Savez društava ekologa Jugoslavije, pp. 605-714.

Lovrenčak, F. 1998: Prsti. In: Fridl, J., Kladnik, D., Orožen Adamič, M. \& Perko, D. (eds.): Geografski atlas Slovenije. Država v prostoru in času. Državna založba Slovenije, Ljubljana, pp. 114-115.

Maarel van der, E. 1979: Transformation of cover-abundance values in phytosociology and its effects on community similarity. Vegetatio 39 (2): 97-114.

Martinčič, A. 2003: Seznam listnatih mahov (Bryopsida) Slovenije. Hacquetia 2 (1): 91-166.

Martinčič, A. 2011: Annotated Checklist of Slovenian Liverworts (Marchanthiophyta) and Hornworts (Anthocerotophyta). Scopolia 72: $1-38$.

Martinčič, A., Wraber, T., Jogan, N., Podobnik, A., Turk, B., Vreš, B., Ravnik, V., Frajman, B., Strgulc Krajšek, S., Trčak, B., Bačič, T., Fischer, M. A., Eler, K. \& Surina, B. 2007: Mala flora Slovenije. Ključ za določanje praprotnic in semenk. Četrta, dopolnjena in spremenjena izdaja. Tehniška založba Slovenije, Ljubljana, 967 pp.

Mucina, L., Bültmann, H., Dierßen, K., Theurillat, J.-P., Raus, T., Čarni, A., Šumberová, K., Willner, W., Dengler, J., Gavilán García, R., Chytrý, M., Hájek, M., Di Pietro, R., Iakushenko, D., Pallas, J., Daniëls, F. J. A., Bergmeier, E., Santos Guerra, A., Ermakov, N., Valachovič, M., Schaminée, J. H. J., Lysenko, T., Didukh, Y. P., Pignatti, S., Rodwell, J. S., Capelo, J., Weber, H. E., Solomeshch, A., Dimopoulos, P., Aguiar, C., Hennekens, S. M. \& Tichý, L. 2016: Vegetation of Europe: hierarchical floristic classification system of vascular plant, bryophyte, lichen, and algal communities. Applied Vegetation Science 19, Suplement 1: 3-264.

Oberdorfer, E. 1957: Süddeutsche Pflanzengesellschaften. Pflanzensoziol. (Jena) 10: 564 pp.

Oberdorfer, E. 1978: Süddeutsche Pflanzengesellschaften. Teil II. 2. Aufl., Gustav Fischer (Stuttgart- New York), 311 pp.

Pignatti, E. \& Pignatti, S. 2014: Plant Life of the Dolomites. Vegetation Structure and Ecology. Publication of the Museum of Nature South Tyrol Nr. 8, Naturmuseum Südtirol, Bozen, Springer Verlag, Heidelberg, 769 pp.

Pignatti, E. \& Pignatti, S. 2016: Plant Life of the Dolomites. Vegetation Tables. Publication of the Museum of Nature South Tyrol Nr. 11, Bozen, Springer Verlag, Heidelberg, 575 pp. 
Podani, J. 2001: SYN-TAX 2000. Computer Programs for Data Analysis in Ecology and Systematics. User's Manual, Budapest, 53 pp.

Poldini, L., Oriolo, G. \& Francescato, C. 2004: Mountain pine scrubs and heaths with Ericaceae in the south-eastern Alps. Plant Biosystems 138 (1): 53-85.

Seliškar, T., Vreš, B. \& Seliškar, A. 2003: FloVegSi 2.0. Fauna, Flora, Vegetation and Paleovegetation of Slovenia. Computer programme for arranging and analysis of biological data. Biološki inštitut ZRC SAZU, Ljubljana.

Sørensen, Th. 1948: A method of establishing groups of equal amplitude in plant sociology based on similarity of species content. Det Kongelige Danske Videnskaberns Selskab, Biologiske Skrifter 5 (4): $1-34$.

Suppan, U., Prügger, J. \& Mayrhofer, H. 2000: Catalogue of the lichenized and lichenicolous fungi of Slovenia. Bibliotheca Lichenologica 76: 1-215.

Surina, B. 2005a: Subalpinska in alpinska vegetacija Krnskega pogorja v Julijskih Alpah. Scopolia 57: 1-122.

Surina, B. 2005b: Asociacija Doronico austriaci-Adenostyletum alliariae Horvat ex Horvat et al. 1974 na Snežniku (Liburnijski kras, SZ Dinaridi). Razprave 4. razreda SAZU 46 (2): 145-160.

Surina, B. 2013: Heaths with dwarf ericaceous shrubs and Alpine juniper (Juniperus alpina) in the Dinaric Alps: A nomenclatorial and synsystematic re-appraisal. Acta Botanica Croatica 72 (1): 113-132.

Surina, B. \& Vreš, B. 2004: Fitocenološka oznaka rastišč vrste Heliosperma pusillum (= Silene pusilla, Caryophyllaceae) v mraziščih na Snežniku (JZ Slovenija). Razprave 4. razreda SAZU 45(2): 147-183.

Šilc, U. \& Čarni, A. 2012: Conspectus of vegetation syntaxa in Slovenia. Hacquetia 11 (1): 113-164.

Weber, H. E., Moravec, J. \& Theurillat, J. P. 2000: International Code of Phytosociological Nomenclature. 3rd Edition. Journal of Vegetation Science 11 (5): 739-766.

Theurillat, J.-P. 2004: Pflanzensoziologisches System. In: Aeschimann, D., K. Lauber, D. M. Moser \& J.-P. Theurillat: Flora alpina 3: Register. Haupt Verlag, Bern, Stuttgart, Wien, pp. 301-313.
Tomažič, G. \& Tregubov, V. 1958: Tabelarni pregled gozdnih tipov. In: Tregubov, V. (ed.): Gozdno gojitveni elaborat na osnovi gozdnih tipov za revir Gomance. Elaborat. Inštitut za gozdno in lesno gospodarstvo Slovenije, Ljubljana, pp. 30-30.

Tomažič, G. \& Tregubov, V. 1959: Tabelarni pregled gozdnih tipov revirja Okroglina. In: Tregubov, V. (ed.): Gozdno gojitveni elaborat na osnovi gozdnih tipov za revir Okroglina. Elaborat. Inštitut za gozdno in lesno gospodarstvo Slovenije, Ljubljana, pp. 35-35.

Trinajstić, I. 2008: Biljne zajednice Republike Hrvatske. Plant communities of Croatia. Akademija šumarskih znanosti, Zagreb, 179 pp.

Vidic, N. J., Prus, T., Grčman, H., Zupan, M., Lisec, A., Kralj, T., Vrščaj, B., Rupreht, J., Šporar, M., Suhadolc, M., Mihelič, R. \& Lobnik, F. 2015: Tla Slovenije s pedološko karto v merilu 1: 250 000. Soils of Slovenia with soil map 1: 250 000. European Union \& University of Ljubljana, Luxemburg, Ljubljana, 152 pp. + maps.

Wraber, T. 1980: Über einige neue oder seltene Arten in der Flora der Julischen Alpen (IV). Studia Geobotanica 1(1): 169-178.

Wraber, T. 1997: Snežnik - gora (tudi) za botanike. Proteus 59 (9-10): 408-421.

Wraber, T. 2000: Botanično raziskovanje na Snežniku. In: Čeligoj, V. (ed.): Knjiga o Snežniku. Planinsko društvo Snežnik, Ilirska Bistrica, pp. 14-24.

Zupančič, B. 1998: Padavine. In: Fridl, J., Kladnik, D., Orožen Adamič, M. \& Perko, D. (eds.): Geografski atlas Slovenije. Država v prostoru in času. Državna založba Slovenije, Ljubljana, pp. 98-99.

Zupančič, M. 2001: Vegetacijska raziskovanja G. Tomažiča na Notranjskem Snežniku. Hladnikia 12-13: 31-39.

Zupančič, M., Wraber, T. \& Žagar, V. 2004: Dinarska združba ruševja Hyperico grisebachii-Pinetum mugo na Snežniku. Razprave 4. razreda SAZU 45(2): 185-261.

Zupančič, M. \& Žagar, V. 2001: Asociacija Salicetum waldsteinianae Beger 1922 v jugovzhodnih apneniških Alpah (Slovenija). Razprave 4. razreda SAZU 42-2: 275-310. 


\section{Number of relevé (Zaporedna številka popisa)}

Database number of relevé (Delovna številka popisa)

Author of the relevé (Avtor popisa)

Elevation in $\mathrm{m}$ (Nadmorska višina $\mathrm{v} \mathrm{m}$ )

Aspect (Lega)

Slope in degrees (Nagib v stopinjah)

Parent material (Matična podlaga)

Soil (Tla)

Stoniness in \% (Kamnitost v \%)

Cover of shrub layer in \% (Zastiranje grmovne plasti v \%)

Cover of herb layer in \% (Zastiranje zeliščne plasti v \%)

Cover of moss layer in \% (Zastiranje mahovne plasti v \%)

Number of species (Število vrst)

Relevé area (Velikost popisne ploskve)

Date of taking relevé (Datum popisa)

Locality (Nahajališče)

Quadrant (Kvadrant)

Coordinate GK Y (D-48)

Coordinate GK X (D-48)
E2

E1

E0

$\mathrm{m}^{2}$

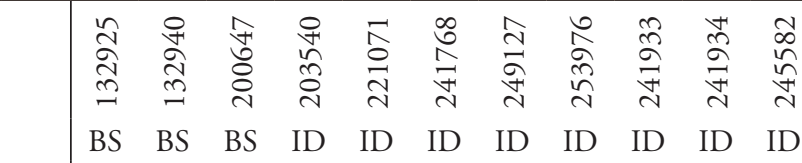

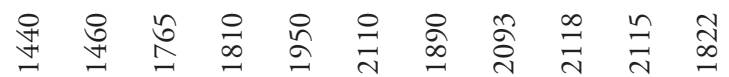

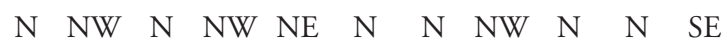

$\begin{array}{lllllllllll}30 & 30 & 20 & 25 & 35 & 40 & 10 & 30 & 15 & 35 & 5\end{array}$

A A A Gr A $A$ DA A A A

$\begin{array}{llllllllll}\mathrm{Li} & \mathrm{Li} & \mathrm{Li} & \mathrm{Re} & \mathrm{Li} & \mathrm{Li} & \mathrm{Re} & \mathrm{Re} & \mathrm{Li}\end{array}$

$\begin{array}{rlllllllll}\text {. } & 10 & 10 & 0 & 20 & 10 & 2 & 5 & 20 & 30\end{array}$

$\begin{array}{lllllllllll}90 & 90 & 90 & 90 & 100 & 80 & 90 & 100 & 90 & 80 & 70\end{array}$

. . . . .

$\begin{array}{lllllllllll}21 & 15 & 25 & 30 & 28 & 28 & 13 & 19 & 25 & 30 & 23\end{array}$

$\begin{array}{lllllllllll}6 & 4 & 4 & 10 & 20 & 4 & 3 & 5 & 4 & 4 & 5\end{array}$

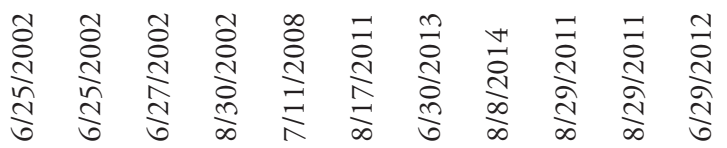

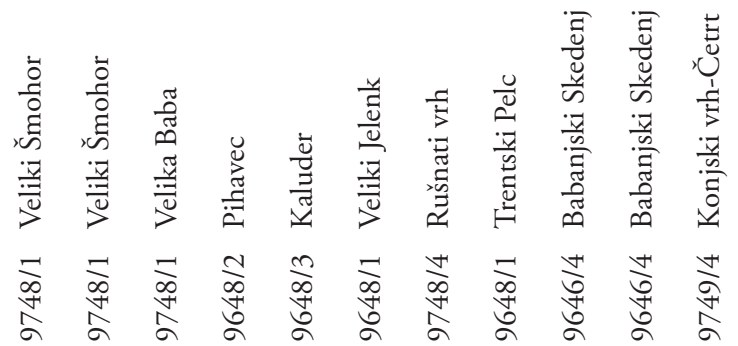

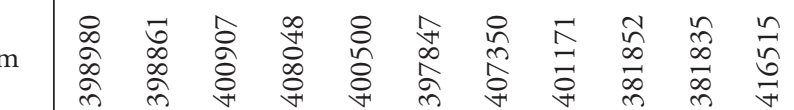

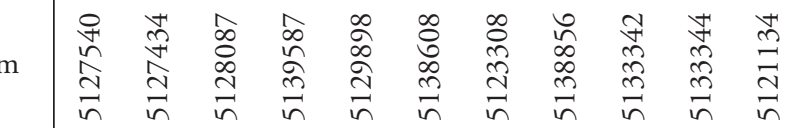

\begin{tabular}{|c|c|c|c|c|c|c|c|c|c|c|c|c|c|}
\hline \multirow[b]{2}{*}{$\mathrm{RE}$} & \multicolumn{13}{|c|}{ Diagnostic species of the associations (Diagnostične vrste asociacije) } \\
\hline & Rhododendron hirsutum & E1 & 1 & 2 & 4 & 2 & 3 & 3 & 4 & 3 & 1 & 2 & 2 \\
\hline $\mathrm{RE}$ & Rhodothamnus chamaecistus & E1 & 4 & 4 & 3 & 3 & 3 & 3 & 3 & 3 & + & 2 & 3 \\
\hline ES & Selaginella selaginoides & E1 & + & . & + & 1 & 1 & 1 & . & + & 1 & 1 & . \\
\hline PC & Valeriana saxatilis & E1 & 1 & + & 1 & 1 & + & . & . & . & + & 1 & + \\
\hline Cfir & Dryas octopetala & E1 & . & . & 1 & 3 & 3 & 2 & 3 & 4 & 3 & 1 & 1 \\
\hline Cfir & Pedicularis rostratocapitata & E1 & . & . & . & 1 & 1 & + & + & + & 1 & 1 & + \\
\hline $\mathrm{CD}$ & Tofieldia calyculata & E1 & 1 & 1 & . & 1 & 1 & + & . & . & . & . & + \\
\hline ES & Homogyne discolor & E1 & . & . & + & 1 & . & 1 & 1 & 1 & . & . & . \\
\hline $\mathrm{MC}$ & Saxifraga aizoides & E1 & . & . & + & 1 & 1 & . & . & + & . & . & . \\
\hline $\mathrm{CD}$ & Pinguicula alpina & E1 & . & . & + & . & + & $\cdot$ & . & . & . & + & . \\
\hline $\mathrm{AC}$ & Salix retusa & E1 & . & . & + & + & . & . & . & . & . & . & . \\
\hline
\end{tabular}




\begin{tabular}{|c|c|c|c|c|c|c|c|c|c|c|c|c|c|c|c|c|c|c|c|c|}
\hline 12 & 13 & 14 & 15 & 16 & 17 & 18 & 19 & 20 & 21 & 22 & 23 & 24 & 25 & 26 & 27 & 28 & 29 & 30 & & \\
\hline 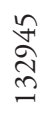 & 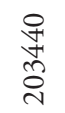 & $\begin{array}{l}\text { ก } \\
\text { ㅇ } \\
\text { त }\end{array}$ & 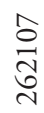 & 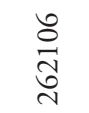 & $\begin{array}{l}\vec{\infty} \\
\stackrel{\text { సे }}{\text { సे }}\end{array}$ & \begin{tabular}{l}
$\stackrel{0}{0}$ \\
\multirow{ర}{*}{} \\
$\stackrel{\sim}{1}$
\end{tabular} & 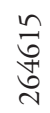 & 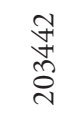 & 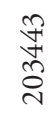 & $\begin{array}{l}\hat{\curvearrowright} \\
\stackrel{n}{\approx}\end{array}$ & 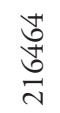 & 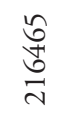 & $\begin{array}{l}\underset{N}{N} \\
\stackrel{n}{v}\end{array}$ & $\underset{\stackrel{N}{N}}{\stackrel{N}{N}}$ & 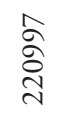 & $\begin{array}{l}\text { ळે } \\
\text { ন }\end{array}$ & $\begin{array}{l}\infty \\
\tilde{n} \\
\approx \\
\approx\end{array}$ & 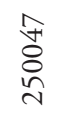 & & \\
\hline BS & ID & BS & ID & ID & ID & ID & ID & ID & ID & ID & ID & ID & ID & ID & ID & ID & ID & ID & & \\
\hline$\stackrel{尺}{\stackrel{Ð}{\unlhd}}$ & $\stackrel{ }{\stackrel{n}{n}}$ & $\stackrel{8}{\circledR}$ & గిర్ర & ᄋ & $\stackrel{\Omega}{\Omega}$ & 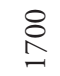 & $\stackrel{\circ}{6}$ & $\underset{\overbrace{}}{\stackrel{8}{0}}$ & હి & 웅 & $\begin{array}{l}\stackrel{\infty}{\infty} \\
\stackrel{n}{n}\end{array}$ & 윰 & $\begin{array}{l}n \\
\stackrel{\infty}{n} \\
\end{array}$ & $\underset{\infty}{\stackrel{\infty}{\infty}}$ & $\underset{\infty}{\stackrel{\infty}{-}}$ & 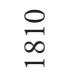 & ๙ิ & $\stackrel{\curvearrowleft}{\stackrel{\infty}{\beth}}$ & & \\
\hline $\mathrm{N}$ & $\mathrm{N}$ & $\mathrm{N}$ & $\mathrm{N}$ & NNW & $\mathrm{N}$ & $\mathrm{N}$ & $\mathrm{N}$ & NNE & $\mathrm{N}$ & $\mathrm{NE}$ & $\mathrm{NE}$ & SEE & NW & $\mathrm{N}$ & $\mathrm{NE}$ & $\mathrm{N}$ & $\mathrm{NE}$ & $\mathrm{NE}$ & & \\
\hline 30 & 30 & 15 & 10 & 10 & 30 & 15 & 30 & 30 & 35 & 30 & 25 & 30 & 25 & 20 & 40 & 15 & 20 & 25 & & \\
\hline A & $\mathrm{DA}$ & A & $\mathrm{Gr}$ & $\mathrm{Gr}$ & A & $\mathrm{D}$ & A & A & A & A & $\mathrm{D}$ & D & A & $\mathrm{AL}$ & A & A & $\mathrm{DA}$ & $\mathrm{DA}$ & & \\
\hline $\mathrm{Li}$ & $\mathrm{Li}$ & $\mathrm{Li}$ & $\mathrm{Re}$ & $\mathrm{Li}$ & $\mathrm{Re}$ & $\mathrm{Li}$ & $\mathrm{Re}$ & $\operatorname{Re}$ & $\operatorname{Re}$ & $\mathrm{Re}$ & $\mathrm{Re}$ & $\operatorname{Re}$ & $\operatorname{Re}$ & $\mathrm{Re}$ & $\mathrm{Re}$ & $\mathrm{Re}$ & $\mathrm{Re}$ & $\mathrm{Re}$ & & \\
\hline . & 10 & . & 10 & 5 & 20 & 5 & 10 & 20 & . & 5 & . & 5 & 5 & 5 & . & . & 10 & . & & \\
\hline . & . & . & . & . & 70 & . & 80 & . & . & 80 & . & . & 10 & . & . & . & . & . & & \\
\hline 90 & 100 & 100 & 90 & 95 & 60 & 100 & 80 & 80 & 100 & 80 & 100 & 100 & 90 & 100 & 100 & 100 & 90 & 100 & & \\
\hline 10 & 5 & 5 & . & . & 10 & 30 & 40 & . & . & . & . & . & . & . & 10 & 5 & . & . & & \\
\hline 46 & 44 & 45 & 31 & 21 & 35 & 35 & 39 & 50 & 51 & 40 & 33 & 43 & 36 & 21 & 37 & 36 & 14 & 21 & & \\
\hline 20 & 4 & 16 & 10 & 10 & 20 & 10 & 30 & 4 & 10 & 40 & 20 & 20 & 20 & 20 & 10 & 10 & 20 & 4 & & \\
\hline 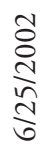 & 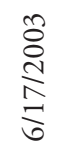 & 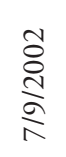 & 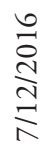 & $\begin{array}{l}0 \\
\stackrel{0}{c} \\
\stackrel{i}{d} \\
\stackrel{N}{N}\end{array}$ & 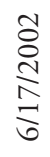 & 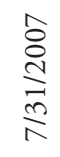 & $\begin{array}{l}0 \\
\stackrel{0}{0} \\
\stackrel{N}{\infty} \\
\stackrel{N}{N} \\
\sigma\end{array}$ & 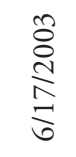 & 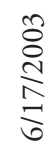 & 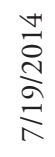 & 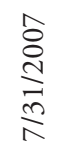 & 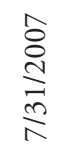 & 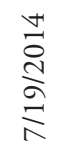 & 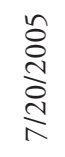 & 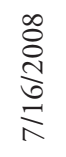 & 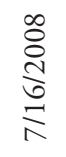 & 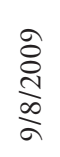 & $\begin{array}{l}\stackrel{n}{\sigma} \\
\stackrel{d}{d} \\
\stackrel{d}{a}\end{array}$ & & \\
\hline 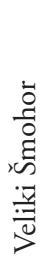 & 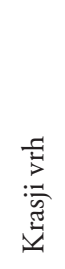 & 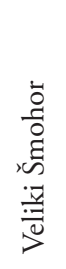 & 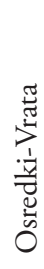 & 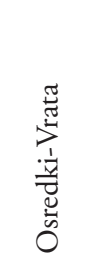 & 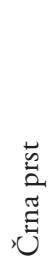 & 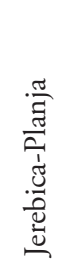 & 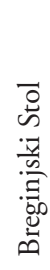 & 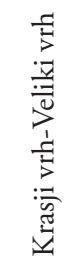 & 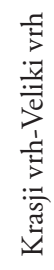 & 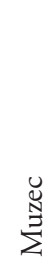 & 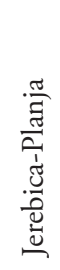 & 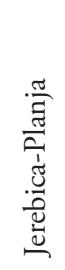 & $\stackrel{\breve{\Xi}}{\Xi}$ & 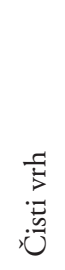 & $\begin{array}{l}\stackrel{y}{\vec{\Xi}} \\
\stackrel{\vec{\Xi}}{\exists}\end{array}$ & 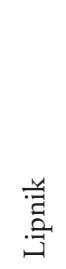 & 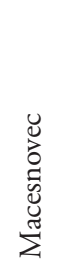 & 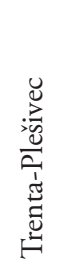 & & \\
\hline 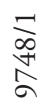 & $\underset{\text { N }}{\stackrel{N}{N}}$ & $\begin{array}{l}\underset{\infty}{\infty} \\
\stackrel{+}{\alpha} \\
\text { 年 }\end{array}$ & 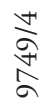 & $\frac{\stackrel{+}{a}}{\stackrel{+}{a}}$ & $\begin{array}{l}\stackrel{+}{a} \\
\stackrel{+}{a} \\
a\end{array}$ & 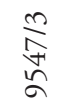 & \begin{tabular}{l}
$\frac{N}{b}$ \\
\multirow{2}{N}{} \\
$\widehat{N}$
\end{tabular} & $\frac{\stackrel{N}{N}}{\stackrel{+}{\alpha}}$ & $\underset{\nwarrow}{\stackrel{N}{N}}$ & $\begin{array}{l}\frac{N}{\sigma} \\
\stackrel{+}{N} \\
\sigma\end{array}$ & $\frac{n}{\stackrel{n}{*}} \underset{n}{n}$ & 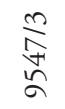 & 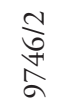 & \begin{tabular}{l}
$\stackrel{N}{\infty}$ \\
\multirow{\infty}{*}{} \\
$\swarrow$
\end{tabular} & 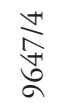 & $\underset{\nwarrow}{\stackrel{Ð}{*}}$ & 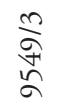 & \begin{tabular}{l}
$\underset{\infty}{\infty}$ \\
\multirow{2}{*}{} \\
$\swarrow$
\end{tabular} & & \\
\hline $\begin{array}{l}\infty \\
\stackrel{n}{\infty} \\
\infty \\
\stackrel{n}{n}\end{array}$ & $\begin{array}{l}\vec{n} \\
\infty \\
\vec{n}\end{array}$ & $\begin{array}{l}\stackrel{\curvearrowright}{\curvearrowright} \\
\stackrel{\curvearrowright}{\curvearrowright}\end{array}$ & $\frac{\stackrel{n}{\sim}}{\stackrel{N}{ }}$ & 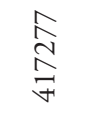 & 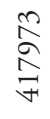 & 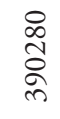 & 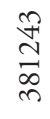 & $\begin{array}{l}\Xi \\
\Xi \\
\bar{\Xi}\end{array}$ & 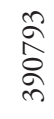 & $\begin{array}{l}\infty \\
n \\
\infty \\
\infty \\
\infty\end{array}$ & 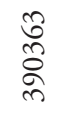 & $\begin{array}{l}\stackrel{2}{n} \\
\tilde{n} \\
\stackrel{2}{2}\end{array}$ & $\begin{array}{l}\wp \\
0 \\
\infty \\
\infty \\
\infty\end{array}$ & 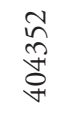 & $\begin{array}{l}\stackrel{2}{\curvearrowright} \\
\text { ๙े }\end{array}$ & $\begin{array}{l}\hat{\infty} \\
\stackrel{\alpha}{\sigma} \\
\stackrel{+}{a}\end{array}$ & 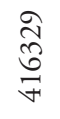 & 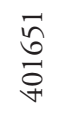 & & \\
\hline $\begin{array}{l}\stackrel{0}{\hat{O}} \\
\stackrel{0}{1} \\
\text { ㄱ }\end{array}$ & $\begin{array}{l}\infty \\
\stackrel{N}{N} \\
\infty \\
\stackrel{N}{\sim}\end{array}$ & 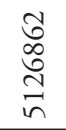 & $\begin{array}{l}\infty \\
\stackrel{0}{2} \\
\stackrel{\sim}{\sim} \\
\stackrel{n}{n}\end{array}$ & $\begin{array}{l}\stackrel{\curvearrowright}{\vec{n}} \\
\stackrel{\sqrt{n}}{n}\end{array}$ & $\begin{array}{l}\tilde{D} \\
\stackrel{n}{n} \\
\stackrel{N}{n}\end{array}$ & $\begin{array}{l}\infty \\
\hat{n} \\
\hat{\sigma} \\
\stackrel{+}{n}\end{array}$ & 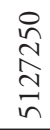 & $\begin{array}{l}0 \\
\sqrt{n} \\
\infty \\
\stackrel{N}{\vec{n}} \\
\sqrt[n]{n}\end{array}$ & 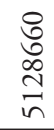 & 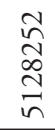 & $\begin{array}{l}\stackrel{2}{\sigma} \\
\stackrel{+}{+} \\
i n\end{array}$ & 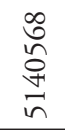 & $\begin{array}{l}\text { సે } \\
\infty \\
\stackrel{\infty}{\sqrt{n}}\end{array}$ & $\begin{array}{l}\text { م } \\
\text { ñ } \\
\text { ñ } \\
\text { n }\end{array}$ & $\begin{array}{l}n \\
8 \\
8 \\
\text { ก) } \\
\text { ñ }\end{array}$ & 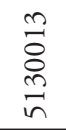 & \begin{tabular}{l}
$\stackrel{2}{2}$ \\
$\stackrel{n}{n}$ \\
\multirow{+}{+}{} \\
$i n$
\end{tabular} & $\begin{array}{l}\stackrel{n}{ \pm} \\
\stackrel{n}{n} \\
\stackrel{n}{n}\end{array}$ & & \\
\hline & & & & & & & & & & & & & & & & & & & Pr. & \\
\hline 4 & 3 & 4 & 3 & 3 & 2 & 3 & 3 & 1 & 3 & 4 & 4 & 1 & 3 & 1 & 3 & 3 & 3 & . & 29 & 97 \\
\hline 2 & 1 & 2 & 2 & 3 & + & 3 & 1 & 1 & + & + & + & . & . & + & . & . & 1 & . & 25 & 83 \\
\hline+ & + & 1 & 3 & . & + & 1 & . & + & . & . & . & . & . & . & . & . & . & + & 16 & 53 \\
\hline+ & . & 1 & + & . & . & + & + & 1 & . & . & . & . & . & . & . & . & . & . & 14 & 47 \\
\hline+ & . & 1 & 1 & 2 & . & . & . & . & . & . & . & . & . & . & . & . & . & . & 13 & 43 \\
\hline . & . & + & + & . & . & + & . & . & . & . & . & . & . & . & . & . & . & . & 11 & 37 \\
\hline+ & . & 1 & 1 & + & . & . & . & . & . & . & . & . & . & . & . & . & . & . & 10 & 33 \\
\hline 1 & . & 1 & + & . & . & . & . & . & . & . & . & . & . & . & . & . & . & . & 8 & 27 \\
\hline+ & + & . & . & . & + & 1 & . & . & . & . & . & . & . & . & . & . & . & . & 8 & 27 \\
\hline$\cdot$ & $\cdot$ & . & + & + & . & + & + & + & . & . & . & . & . & . & . & . & . & . & 8 & 27 \\
\hline . & + & + & . & . & + & 1 & + & . & . & . & . & . & . & . & . & . & . & . & 7 & 23 \\
\hline
\end{tabular}




\begin{tabular}{|c|c|c|c|c|c|c|c|c|c|c|c|c|c|}
\hline & Number of relevé (Zaporedna številka popisa) & & 1 & 2 & 3 & 4 & 5 & 6 & 7 & 8 & 9 & 10 & 11 \\
\hline Cfir & Carex firma & E1 & 1 & 1 & 1 & 2 & 3 & + & 1 & 2 & 2 & 1 & 2 \\
\hline Cfir & Sesleria sphaerocephala & E1 & . & . & + & . & . & + & + & 1 & 3 & 3 & . \\
\hline Cfir & Phyteuma sieberi & E1 & . & . & + & . & + & . & . & + & + & . & + \\
\hline SV & Ranunculus carinthiacus & E1 & . & . & . & . & . & . & . & . & . & . & . \\
\hline ES & Anemone narcissiflora & E1 & . & . & . & . & . & . & . & . & . & . & . \\
\hline $\mathrm{OE}$ & Carex atrata & E1 & . & . & . & . & . & . & . & . & . & . & . \\
\hline $\mathrm{MuA}$ & Viola biflora & E1 & 1 & . & . & . & + & . & . & . & . & . & $\cdot$ \\
\hline $\mathrm{BA}$ & Salix waldsteiniana & E2 & . & . & . & . & . & . & . & . & . & . & . \\
\hline VP & Rosa pendulina & E1 & . & . & . & . & . & . & . & . & . & . & . \\
\hline VP & Luzula sylvatica & E1 & . & . & . & . & . & . & . & . & . & . & . \\
\hline VP & Vaccinium myrtillus & E1 & . & . & . & . & . & . & . & . & . & . & . \\
\hline BA & Sorbus chamaemespilus & E2a & . & . & . & . & . & . & . & . & . & . & . \\
\hline JT & Campanula scheuchzeri & E1 & $\cdot$ & . & . & . & . & . & . & . & . & + & . \\
\hline NS & Festuca nigrescens & E1 & . & . & . & . & . & . & . & . & . & . & . \\
\hline LV & Empetrum hermaphroditum & E1 & . & . & . & . & . & . & . & . & . & . & . \\
\hline RE & Rhododendron $x$ intermedium & E1 & . & . & . & . & . & . & . & . & . & . & . \\
\hline \multirow[t]{3}{*}{$\mathrm{RE}$} & Rhododendro hirsuti-Ericetalia carneae & & & & & & & & & & & & \\
\hline & Pinus mugo & E2 & . & . & + & + & . & . & . & . & . & . & . \\
\hline & Erica carnea & E1 & . & . & . & . & . & . & . & . & . & . & . \\
\hline \multirow[t]{8}{*}{ CFir } & Caricion firmae & & & & & & & & & & & & \\
\hline & Salix alpina & E1 & . & . & . & $\mathrm{r}$ & . & + & . & . & + & . & . \\
\hline & Festuca quadriflora & E1 & . & . & . & . & . & + & . & . & 2 & 1 & . \\
\hline & Helianthemum alpestre & E1 & . & . & . & . & + & . & . & + & . & . & 1 \\
\hline & Oxytropis neglecta & E1 & . & . & . & + & . & . & . & + & . & 1 & . \\
\hline & Silene acaulis & E1 & . & . & . & 2 & . & . & . & . & + & + & . \\
\hline & Primula wulfeniana & E1 & . & . & . & . & . & . & 1 & . & . & . & + \\
\hline & Ranunculus hybridus & E1 & . & . & . & . & . & . & . & . & . & . & . \\
\hline \multirow[t]{3}{*}{$\mathrm{OE}$} & Oxytropido-Elynion & & & & & & & & & & & & \\
\hline & Lloydia serotina & E1 & . & . & . & . & . & . & . & . & + & . & . \\
\hline & Gentiana nivalis & E1 & . & . & . & . & . & . & . & . & . & . & . \\
\hline \multirow[t]{6}{*}{ CA } & Caricion austroalpinae & & & & & & & & & & & & \\
\hline & Laserpitium peucedanoides & E1 & + & . & . & . & . & . & . & . & . & . & . \\
\hline & Koeleria eriostachya & E1 & . & . & . & . & . & . & . & . & . & . & . \\
\hline & Pulsatilla alpina subsp. austroalpina & E1 & . & . & . & . & . & . & . & . & . & . & . \\
\hline & Festuca calva & E1 & . & . & . & . & . & . & . & . & . & . & . \\
\hline & Arabis vochinensis & E1 & . & . & . & . & . & . & . & . & . & . & . \\
\hline \multirow[t]{9}{*}{$\mathrm{CF}$} & Caricion ferrugineae & & & & & & & & & & & & \\
\hline & Carex ferruginea & E1 & . & . & + & . & . & . & . & . & . & . & . \\
\hline & Hedysarum hedysaroides & E1 & . & . & . & . & 1 & . & . & . & . & . & . \\
\hline & Knautia longifolia & E1 & . & . & . & . & . & . & . & . & . & . & . \\
\hline & Gentiana pumila & E1 & . & . & . & . & . & . & . & . & . & + & . \\
\hline & Cerastium subtriflorum & E1 & $\cdot$ & $\cdot$ & . & . & . & $\cdot$ & . & . & . & . & . \\
\hline & Pedicularis rostrato-spicata & E1 & . & . & . & . & . & . & . & . & . & . & . \\
\hline & Serratula macrocephala & E1 & . & $\cdot$ & . & . & . & $\cdot$ & . & . & . & . & . \\
\hline & Malaxis monophyllos & E1 & . & . & . & . & . & . & . & . & $\cdot$ & . & . \\
\hline \multirow[t]{7}{*}{ SV } & Seslerietalia coeruleae & & & & & & & & & & & & \\
\hline & Galium anisophyllum & E1 & . & . & . & . & . & . & . & . & + & . & + \\
\hline & Achillea clavenae & E1 & . & . & . & . & . & + & + & + & + & 1 & . \\
\hline & Juncus monanthos & E1 & + & 1 & . & . & . & $\cdot$ & . & $\cdot$ & . & . & . \\
\hline & Gentiana clusii & E1 & + & $\cdot$ & + & + & + & . & . & . & . & . & . \\
\hline & Potentilla crantzii & E1 & $\cdot$ & $\cdot$ & . & . & . & . & . & . & . & . & . \\
\hline & Helictotrichon parlatorei & E1 & . & . & . & . & . & . & . & . & . & . & . \\
\hline
\end{tabular}




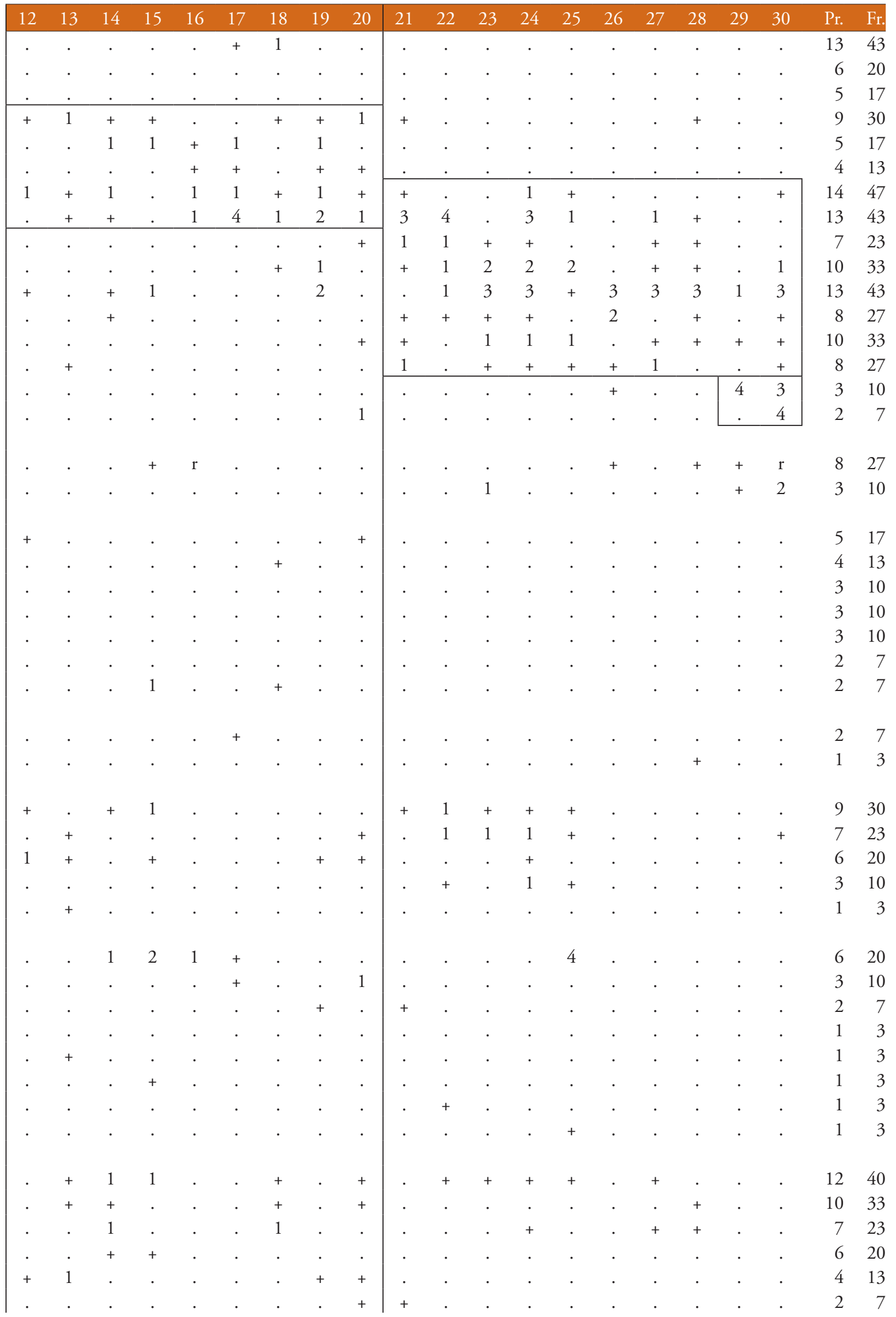


Leucanthemum heterophyllum

Nigritella rubra agg. (N. bicolor)

Thesium alpinum

Saussurea discolor

ES Elyno-Seslerietea

Sesleria caerulea

Aster bellidiastrum

Bartsia alpina

Polygonum viviparum

Astrantia bavarica

Carex sempervirens

Hieracium villosum

Betonica alopecuros

Phyteuma orbiculare

Anthyllis vulneraria subsp. alpestris

Linum julicum

Pedicularis verticillata

Thymus praecox subsp. polytrichus

Alchemilla alpigena

Lotus alpinus

Euphrasia salisburgensis

Agrostis alpina

Polygala alpestris

Helianthemum nummularium subsp. grandiflorum

Campanula witasekiana

Nigritella rhellicani

Gentianella anisodonta

Daphne striata

Alchemilla fallax

Gentiana verna

Hieracium pilosum

Scabiosa lucida

Cerastium strictum

NS Nardion strictae

Coeloglossum viride

Potentilla erecta

Alchemilla flabellata

Gentiana pannonica

JT Juncetea trifidi

Anthoxanthum nipponicum

Botrychium lunaria

Euphrasia minima

Potentilla aurea

Leontodon helveticus

LV Loiseleurio-Vaccinietea

Arctostaphylos alpinus

Vaccinium gaultherioides

AC Arabidetalia caeruleae (inc. Salicetea herbaceae)

Soldanella alpina

Ranunculus traunfellneri

Doronicum glaciale

Trifolium pallescens

E1

E1

E1

E1

E1

E1

E1

E1

E1

E1

E1

E1

E1

E1

E1

E1

E1

E1

E1

E1

E1

E1

E1

E1

E1

E1

E1

E1

E1

E1

E1

E1

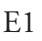

E1

E1

E1

E1

E1

E1

E1

E1

E1

E1

E1

E1

E1

E1 $\begin{array}{lllllllllll}1 & 2 & 3 & 4 & 5 & 6 & 7 & 8 & 9 & 10 & 11\end{array}$ 


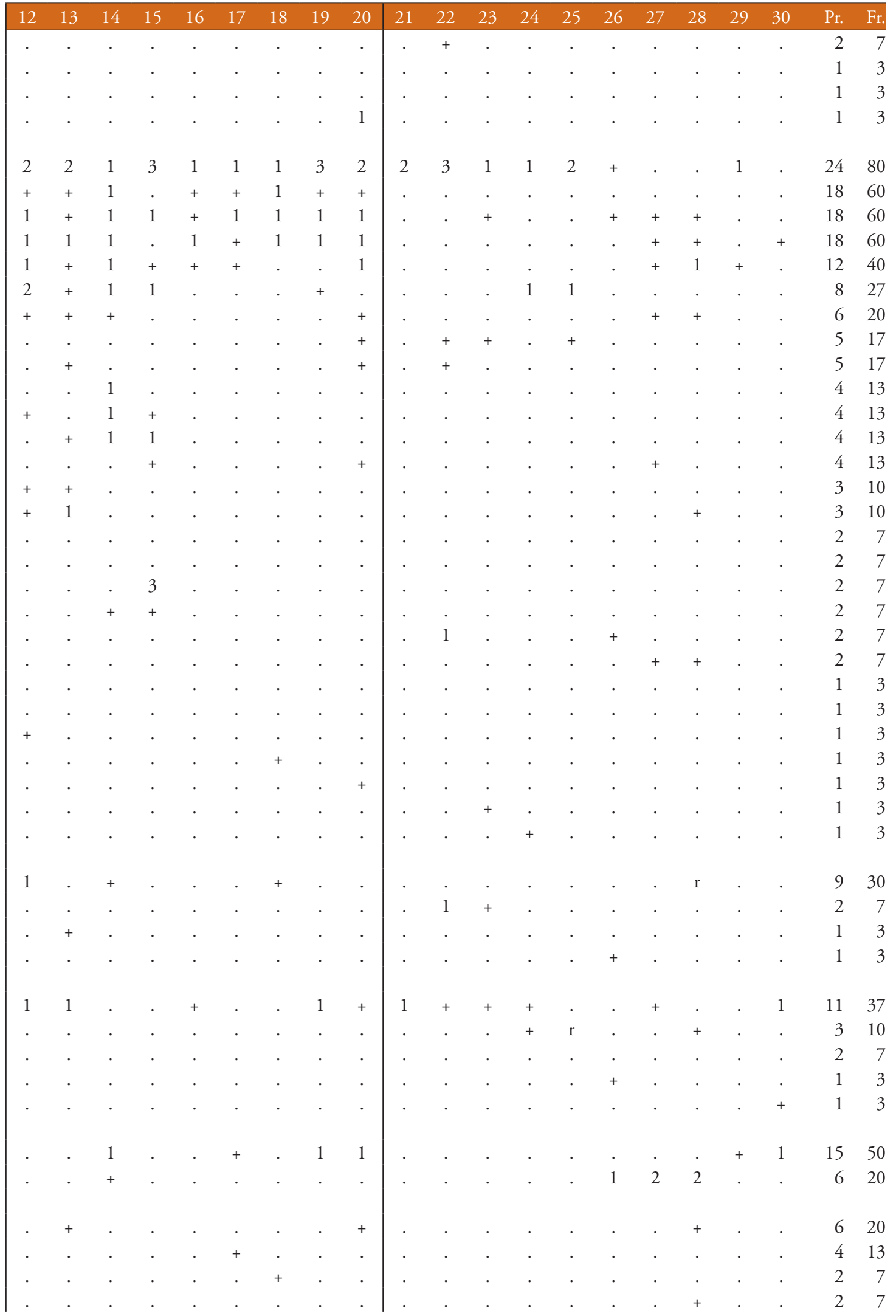




\begin{tabular}{|c|c|c|c|c|c|c|c|c|c|c|c|c|c|}
\hline & Number of relevé (Zaporedna številka popisa) & & 1 & 2 & 3 & 4 & 5 & 6 & 7 & 8 & 9 & 10 & 11 \\
\hline & Thlaspi minimum (T. kerneri) & E1 & . & + & . & . & . & . & . & . & . & . & . \\
\hline & Salix serpyllifolia & E1 & . & . & + & . & . & . & . & . & . & . & . \\
\hline & Soldanella minima & E1 & . & . & + & . & . & . & . & . & . & . & . \\
\hline & Carex ornithopodoides & E1 & . & . & . & . & . & . & . & . & . & . & + \\
\hline & Salix reticulata & E1 & . & . & . & . & . & . & . & . & . & $\cdot$ & . \\
\hline & Alchemilla fissa & E1 & . & . & . & . & . & . & . & . & . & . & . \\
\hline \multirow[t]{16}{*}{ TR } & Thlaspietea rotundifolii & & & & & & & & & & & & \\
\hline & Heliosperma alpestre & E1 & . & . & 1 & . & . & . & . & $\cdot$ & . & . & . \\
\hline & Biscutella laevigata & E1 & . & + & . & . & . & . & . & . & . & . & . \\
\hline & Rhodiola rosea & E1 & . & . & . & . & . & . & . & . & . & . & . \\
\hline & Aquilegia einseleana & E1 & 1 & + & . & . & . & . & . & . & . & . & . \\
\hline & Athamanta cretensis & E1 & + & + & . & . & . & . & . & . & . & $\cdot$ & . \\
\hline & Armeria alpina & E1 & . & . & + & . & . & . & . & $\cdot$ & . & $\cdot$ & . \\
\hline & Festuca nitida & E1 & . & . & . & . & . & . & . & $\cdot$ & . & $\cdot$ & . \\
\hline & Molopospermum peloponnesiacum subsp. bauhinii & E1 & . & . & . & . & $\cdot$ & . & . & . & . & . & . \\
\hline & Festuca laxa & E1 & + & . & . & . & . & . & . & . & . & . & . \\
\hline & Rumex scutatus & E1 & + & . & . & . & . & . & . & . & . & . & . \\
\hline & Gymnocarpium robertianum & E1 & . & . & . & . & . & . & . & . & . & . & . \\
\hline & Campanula cochleariifolia & E1 & . & . & . & . & . & . & . & . & . & . & . \\
\hline & Pimpinella alpina & E1 & . & . & . & . & . & . & . & . & . & . & . \\
\hline & Valeriana montana & E1 & . & . & . & . & $\cdot$ & . & . & $\cdot$ & . & $\cdot$ & . \\
\hline & Hieracium bifidum & E1 & . & . & . & . & $\cdot$ & . & . & . & . & . & . \\
\hline \multirow[t]{4}{*}{ PS } & Physoplexido-Saxifragion petraeae & & & & & & & & & & & & \\
\hline & Paederota lutea & E1 & + & . & . & . & . & . & . & . & . & . & . \\
\hline & Saxifraga crustata & E1 & . & . & . & + & . & . & . & . & . & + & . \\
\hline & Saxifraga squarrosa & E1 & . & . & . & . & · & + & . & $\cdot$ & . & + & . \\
\hline \multirow[t]{2}{*}{ PC } & Potentilletalia caulescentis & & & & & & & & & & & & \\
\hline & Primula auricula & E1 & + & . & . & . & . & . & . & . & . & . & . \\
\hline \multirow[t]{3}{*}{ Cy } & Cystopteridion fragilis & & & & & & & & & & & & \\
\hline & Carex brachystachys & E1 & 1 & + & . & . & . & . & . & . & . & $\cdot$ & . \\
\hline & Cystopteris regia & E1 & . & + & . & . & . & . & . & . & . & $\cdot$ & . \\
\hline \multirow[t]{4}{*}{ AT } & Asplenietea trichomanis & & & & & & & & & & & & \\
\hline & Asplenium viride & E1 & . & + & . & . & . & . & . & . & . & . & . \\
\hline & Valeriana tripteris & E1 & . & . & . & . & . & . & . & . & . & . & . \\
\hline & Saxifraga paniculata & E1 & . & . & . & + & . & . & . & . & . & . & . \\
\hline \multirow[t]{3}{*}{ CD } & Caricetalia davallianae & & & & & & & & & & & & \\
\hline & Parnassia palustris & E1 & . & . & + & . & + & + & . & . & . & $\cdot$ & . \\
\hline & Carex capillaris & E1 & . & . & . & . & $\cdot$ & . & . & . & . & $\cdot$ & . \\
\hline \multirow[t]{7}{*}{ PoT } & Poo alpinae-Trisetetalia & & & & & & & & & & & & \\
\hline & Poa alpina & E1 & . & . & . & . & . & . & . & . & 1 & + & . \\
\hline & Trollius europaeus & E1 & . & . & . & . & . & . & . & . & . & . & . \\
\hline & Phleum rhaeticum & E1 & . & . & . & . & . & . & . & . & . & . & . \\
\hline & Euphrasia picta & E1 & . & . & . & . & . & . & . & . & . & . & . \\
\hline & Alchemilla xanthochlora & E1 & . & . & . & . & $\cdot$ & . & . & . & . & $\cdot$ & . \\
\hline & Ranunculus nemorosus & E1 & . & . & . & . & $\cdot$ & . & . & $\cdot$ & . & $\cdot$ & . \\
\hline \multirow[t]{6}{*}{ MA } & Molinio-Arrbenatheretea & & & & & & & & & & & & \\
\hline & Lathyrus pratensis & E1 & . & . & . & . & . & . & . & . & . & . & . \\
\hline & Veronica chamaedrys & E1 & . & . & . & . & 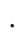 & . & . & . & . & $\cdot$ & . \\
\hline & Trifolium repens & E1 & . & . & . & . & . & . & . & . & . & . & . \\
\hline & Leontodon hispidus & E1 & $\cdot$ & . & . & $\cdot$ & . & . & . & . & . & . & . \\
\hline & Dactylis glomerata & E1 & . & . & . & . & . & . & . & . & . & $\cdot$ & . \\
\hline
\end{tabular}




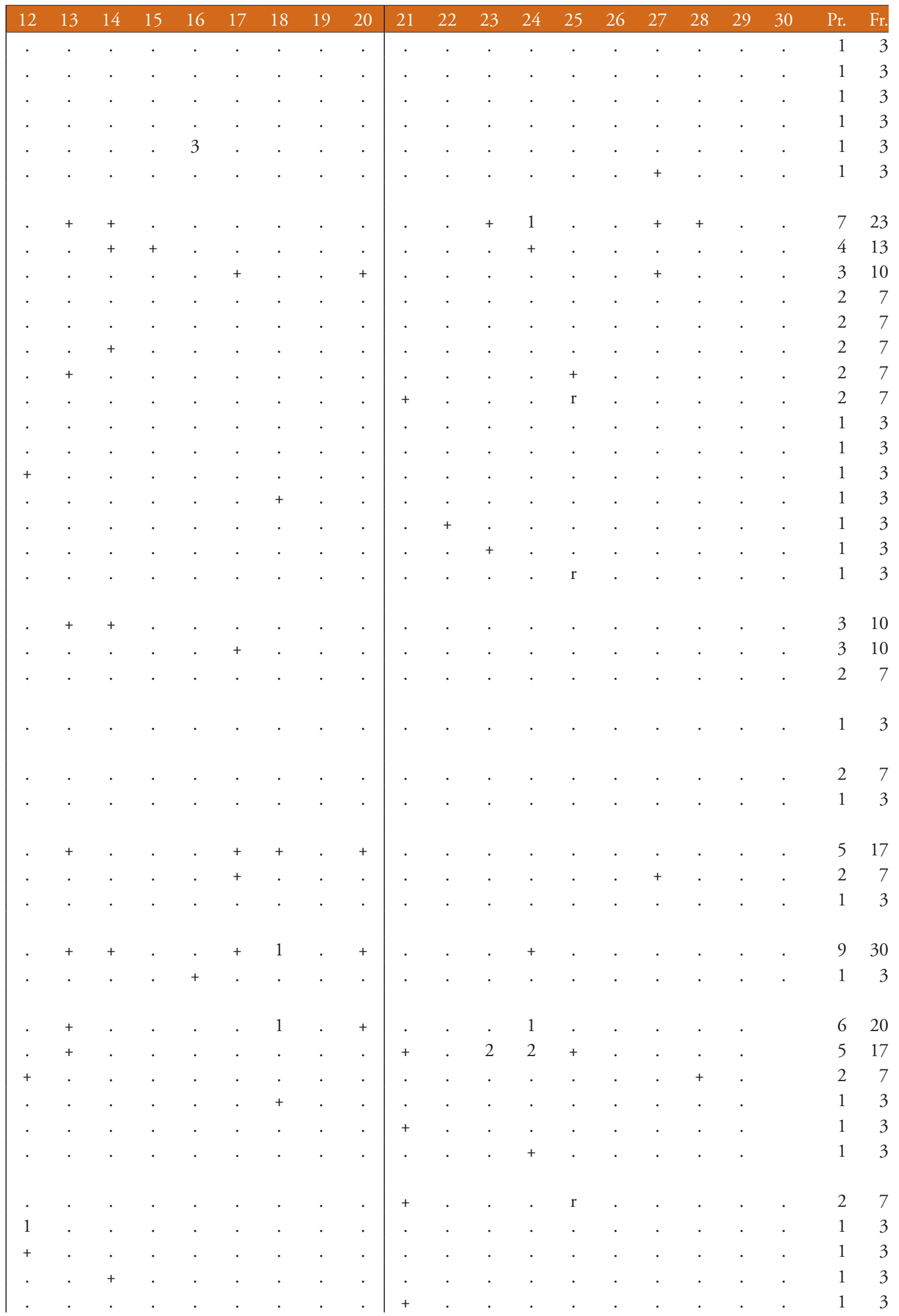


Number of relevé (Zaporedna številka popisa)

Deschampsia cespitosa

Trifolium pratense

FB Festuco-Brometea

Gymnadenia conopsea

Bromopsis transsilvanica

TG Trifolio-Geranietea

Laserpitium siler

Libanotis sibirica subsp. montana

Polygonatum odoratum

Silene nutans

MuA Mulgedio-Aconitetea

Geranium sylvaticum

Veratrum album subsp. lobelianum

Aconitum lycoctonum agg. (A. lupicida)

Hypericum maculatum

Aconitum angustifolium

Athyrium filix-femina

Ranunculus platanifolius

Peucedanum ostruthium

Chaerophyllum hirsutum

Poa bybrida

Hieracium valdepilosum

Senecio cacaliaster

Polygonatum verticillatum

Rumex arifolius

BA Betulo-Alnetea viridis

Juniperus alpina

Salix appendiculata

Salix glabra

Alnus viridis

SS Sambuco-Salicion capreae

Sorbus aucuparia

Rubus idaeus

Fragaria vesca

EP Erico-Pinetea

Carex ornithopoda

Rubus saxatilis

Chamaecytisus hirsutus

Molinia caerulea subsp. arundinacea

VP Vaccinio-Piceetea

Homogyne alpina

Vaccinium vitis-idaea

Clematis alpina

Solidago virgaurea

Maianthemum bifolium

Huperzia selago

Picea abies

Lycopodium annotinum

Polystichum lonchitis

Calamagrostis villosa

Dryopteris expansa

Rhododendron ferrugineum
E1

E1

E1

E1

E1

E1

E1

E1

E1

E1

E1

E1

E1

E1

E1

E1

E1

E1

E1

E1

E1

E2a

E2

E2

E2a

E2a

E2a

E1

E1

E1

E1

E1

E1

E1

E2a

E1

E1

E1

E2a

E1

E1

E1

E1

E1

.

$\cdot$ 


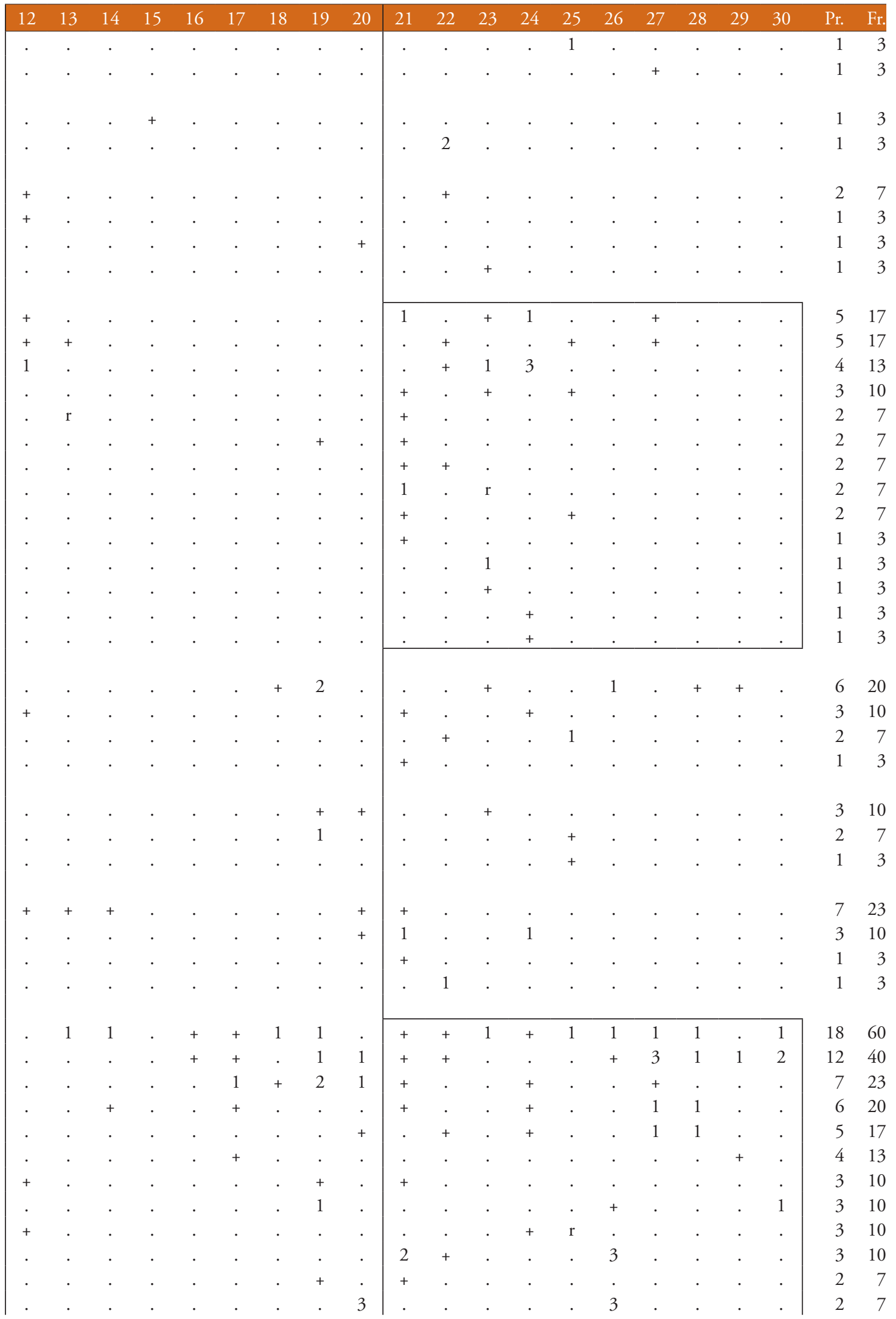


Number of relevé (Zaporedna številka popisa)

E2

Aposeris foetida

Melampyrum sylvaticum

Luzula luzuloides

Lonicera caerulea

Pyrola minor

Luzula luzulina

Oxalis acetosella

Dryopteris dilatata

Calamagrostis arundinacea

Hieracium murorum

Saxifraga cuneifolia

Gymnocarpium dryopteris

TA Tilio-Acerion

Thalictrum aquilegiifolium

Acer pseudoplatanus

FS Fagetalia sylvaticae

Lilium martagon

Dryopteris filix-mas

Anemone trifolia

Luzula nivea

Melica nutans

Daphne mezereum

Galium laevigatum

QF Querco-Fagetea

Hepatica nobilis

Hieracium lachenalii

Dactylorhiza fuchsii

Platanthera bifolia

O Other species (Druge vrste)

Festuca sp.

Vicia sp.

ML Mosses and lichens (Mahovi in lišaji)

Hylocomium splendens

Rhytidiadelphus triquetrus

Tortella tortuosa

Dicranum sp.

Tortella sp.

Dicranum scoparium

Peltigera leucophlebia

Rhytidiadelphus loreus

Cetraria islandica

Cladonia furcata
E1

E1

E1

E2a

E1

E1

E1

E1

E1

E1

E1

E1

E1

E1

E1

E1

E1

E1

E1

E1

E1

E1

E1

E1

E1

E1

E1

E0

E0

E0

E0

E0

E0

E0

E0

E0

E0

.

2




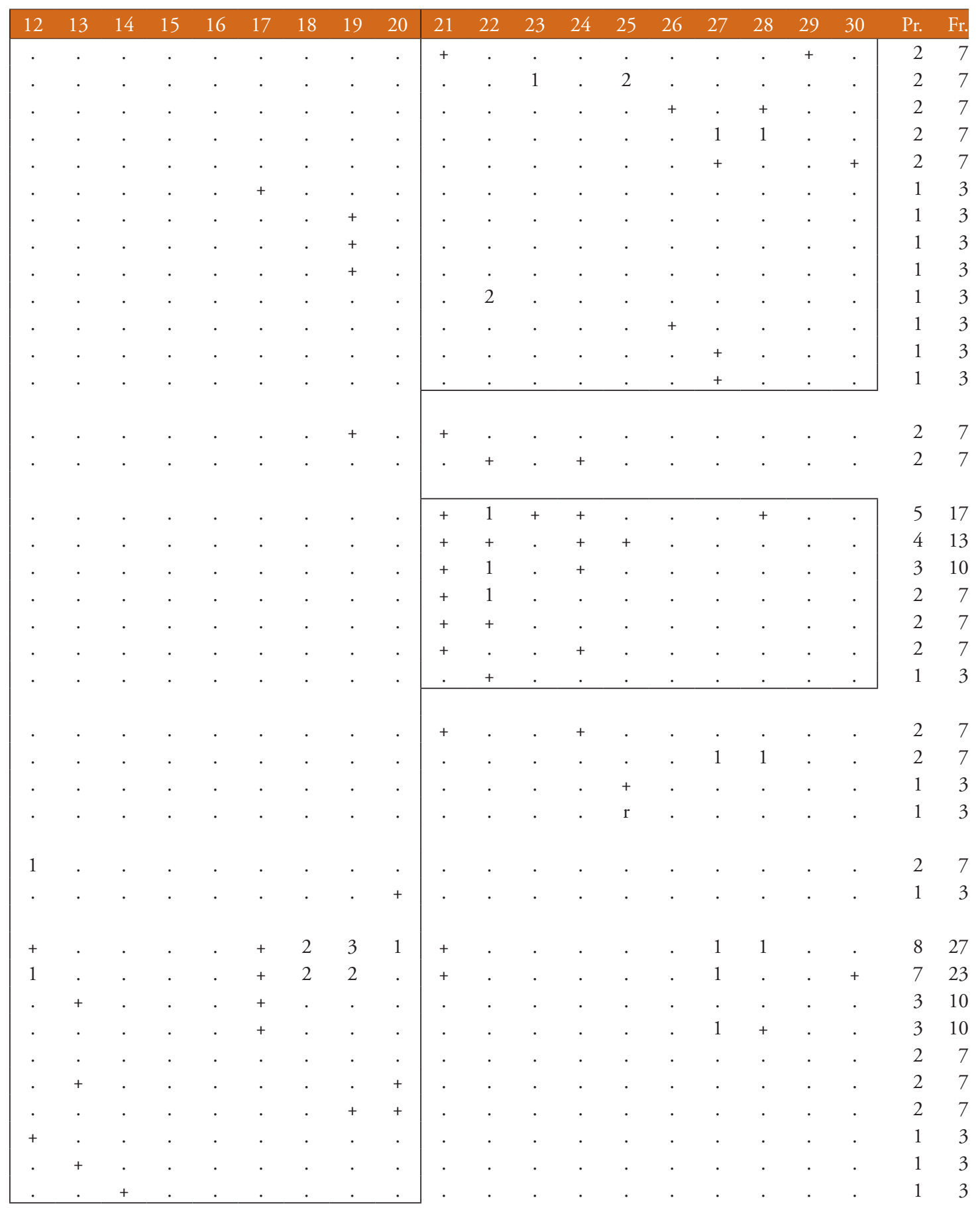




\section{Number of relevé (Zaporedna številka popisa)}

Database number of relevé (Delovna številka popisa)

Author of the relevé (Avtor popisa)

Elevation in $\mathrm{m}$ (Nadmorska višina $\mathrm{v} \mathrm{m})$

Aspect (Lega)

Slope in degrees (Nagib v stopinjah)

Parent material (Matična podlaga)

Soil (Tla)

Stoniness in \% (Kamnitost v \%)

Cover of shrub layer in \% (Zastiranje grmovne plasti v \%)

Cover of herb layer in \% (Zastiranje zeliščne plasti v \%):

Cover of moss layer in \% (Zastiranje mahovne plasti v \%):

Number of species (Število vrst)

Relevé area (Velikost popisne ploskve)

Date of taking relevé (Datum popisa)

Locality (Nahajališ̌ce)

Quadrant (Kvadrant)

Coordinate GK Y (D-48)

Coordinate GK X (D-48)

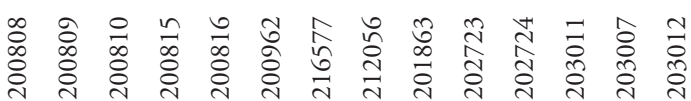

BS BS BS BS BS BS ID ID TW ID ID ID ID ID స్ర \&

NW NW NW $\quad \mathrm{N} \quad \mathrm{N}$ NE NE $\mathrm{N}$ N $\mathrm{NE} \quad \mathrm{N}$ NE $\mathrm{N}$ NNE $\begin{array}{llllllllllllll}25 & 25 & 20 & 30 & 30 & 30 & 30 & 35 & 30 & 5 & 20 & 10 & 35 & 40\end{array}$ A A A A A A A Gr A DA A A Gr A $\operatorname{Re} \operatorname{Re} \operatorname{Re} \operatorname{Re} \operatorname{Re} \operatorname{Re} \operatorname{Re} \mathrm{Li} \operatorname{Re} \mathrm{Li} \operatorname{Re} \operatorname{Re} \mathrm{Li} \operatorname{Re}$ $\begin{array}{llllllllllll}. & . & . & . & . & 20 & . & 10 & 10 & 20 & 30 & 30\end{array}$

$\begin{array}{lllllllllllllll}\text { E2 } & 90 & 100 & 100 & 95 & 100 & 100 & 80 & 60 & 100 & 70 & 80 & 30 & 30 & 40\end{array}$ $\begin{array}{lllllllllllllll}\mathrm{E} 1 & 60 & 50 & 40 & 10 & 10 & 70 & 60 & 50 & 60 & 60 & 60 & 70 & 70 & 90\end{array}$

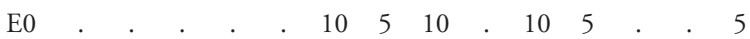
$\begin{array}{llllllllllllll}49 & 43 & 38 & 38 & 31 & 34 & 41 & 35 & 31 & 53 & 74 & 25 & 39 & 41\end{array}$

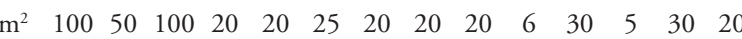
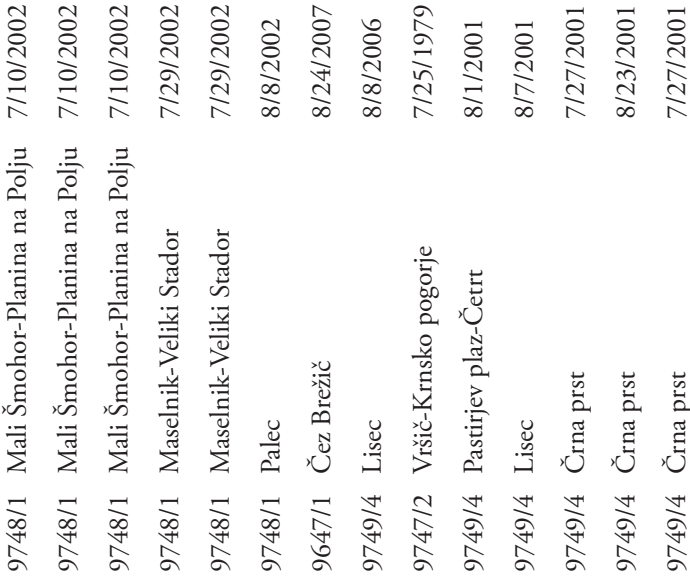

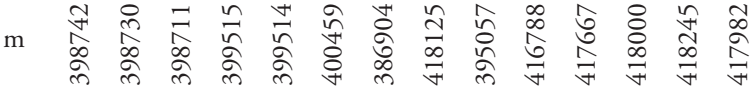

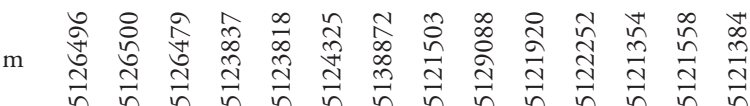

BA Salix waldsteiniana

CA Laserpitium peucedanoides

CF Carex ferruginea

ES Astrantia bavarica

BA Salix glabra

TR Rhodiola rosea

ES Selaginella selaginoides

CA Pulsatilla alpina subsp. austroalpina

$\mathrm{MuA}$ Aconitum angustifolium

EP Rhodothamnus chamaecistus

VP Homogyne sylvestris

CF Hedysarum hedysaroides

\begin{tabular}{|c|c|c|c|c|c|c|c|c|c|c|c|c|c|c|}
\hline E2 & 4 & 5 & 5 & 5 & 5 & 5 & 4 & 3 & 3 & 2 & 3 & 2 & 2 & 14100 \\
\hline+ & + & + & + & . & . & + & 1 & . & + & + & . & 1 & + & $\begin{array}{ll}10 & 71\end{array}$ \\
\hline 2 & 2 & . & 1 & . & $\cdot$ & 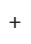 & $J$ & 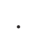 & 1 & + & . & 3 & , & 964 \\
\hline+ & 1 & + & 1 & . & . & 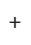 & 1 & . & . & + & ${ }^{\circ}$ & & 1 & 964 \\
\hline 2 & 2 & + & . & . & . & & & 2 & 2 & 3 & 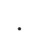 & & 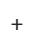 & 857 \\
\hline+ & + & + & . & . & + & 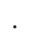 & + & + & $\cdot$ & . & + & & . & 750 \\
\hline+ & + & . & . & . & . & . & + & 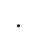 & + & . & + & 1 & 1 & 750 \\
\hline$\cdot$ & + & . & + & + & . & + & . & . & $\cdot$ & $r$ & $\cdot$ & $T^{T}$ & $\cdot$ & 643 \\
\hline 1 & 1 & 2 & + & + & + & $\cdot$ & $\cdot$ & . & . & 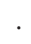 & $\cdot$ & $\cdot$ & $\cdot$ & 643 \\
\hline+ & . & . & + & . & . & . & . & . & . & . & . & . & 1 & 321 \\
\hline$\cdot$ & . & . & . & . & . & . & . & . & + & $r$ &. & . & 1 & 321 \\
\hline . & . & . & . & . & . & . & . & . & . & . & 1 & + & 1 & \\
\hline
\end{tabular}




\section{Number of relevé (Zaporedna številka popisa)

$\begin{array}{llllllllllllllll}1 & 2 & 3 & 4 & 5 & 6 & 7 & 8 & 9 & 10 & 11 & 12 & 13 & 14 & \text { Pr. Fr. }\end{array}$

Differential species of lower units (Razlikovalne vrste nižjih enot)

MuA Saxifraga rotundifolia

MuA Primula elatior

PAT Poa alpina

PAT Phleum rhaeticum

BA Betulo-Alnetea viridis

Salix appendiculata

Sorbus chamaemespilus

Alnus viridis

Juniperus alpina

Pedicularis recutita

MuA Mulgedio-Aconitetea

Veratrum album subsp. lobelianum

Viola biflora

Chaerophyllum villarsii

Aconitum lycoctonum agg. (A. lupicida)

Heracleum sphondylium subsp. montanum

Rumex arifolius

Geranium sylvaticum

Geum rivale

Hypericum maculatum

Pleurospermum austriacum

Adenostyles alliariae

Ranunculus platanifolius

Senecio ovatus

Athyrium filix-femina

Epilobium alpestre

Senecio cacaliaster

Hieracium prenanthoides

Crepis pyrenaica

Athyrium distentifolium

Peucedanum ostruthium

Chaerophyllum hirsutum

Tephroseris longifolia

Eryngium alpinum

Polygonatum verticillatum

Aconitum degenii subsp. paniculatum

Carduus personata

Crepis paludosa

Poa hybrida

Silene vulgaris subsp. antelopum

RE Rhododendro hirsuti-Ericetalia carneae

Rhododendron hirsutum

CFir Caricion firmae

Ranunculus hybridus

Carex firma

Pedicularis rostratocapitata

Phyteuma sieberi

Dryas octopetala

CA Caricion austroalpinae

Heracleum austriacum subsp. siffolium

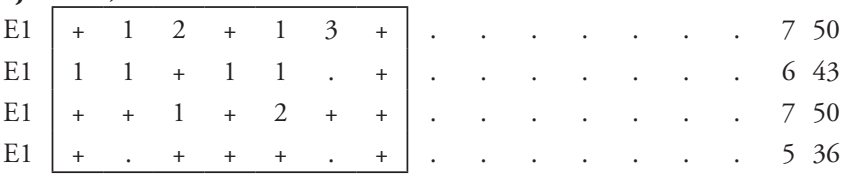
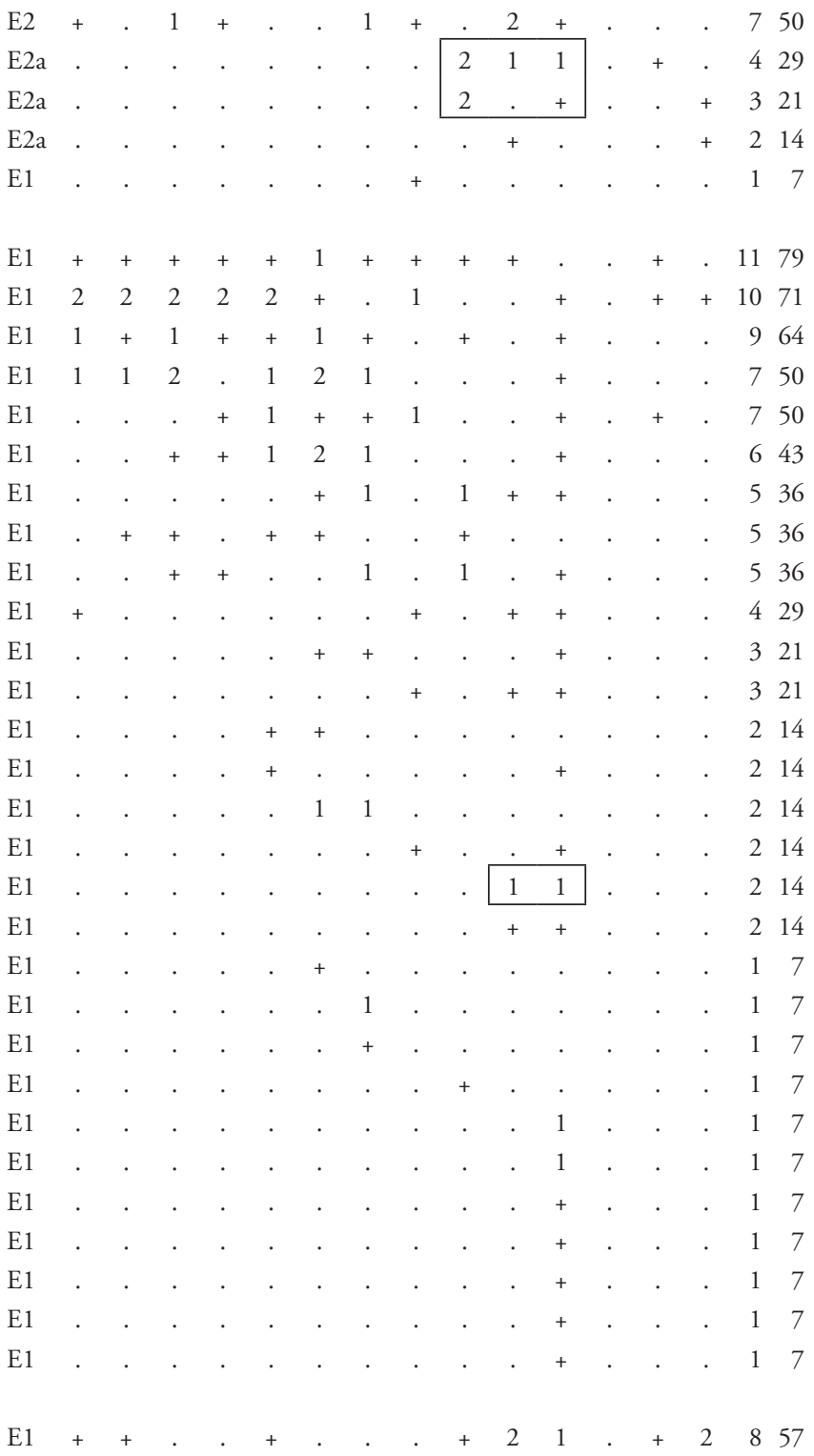

E1

E1

E1

E1

E1

\begin{tabular}{|rrr|rr}
\hline$\cdot$ & 1 & + & 3 & 21 \\
+ & + & + & 3 & 21 \\
+ & $\cdot$ & + & 2 & 14 \\
$\mathrm{r}$ & $\cdot$ & + & 2 & 14 \\
$\cdot$ & $\cdot$ & + & 1 & 7
\end{tabular}

E1 
Number of relevé (Zaporedna številka popisa)

$\begin{array}{llllllllllllllll}1 & 2 & 3 & 4 & 5 & 6 & 7 & 8 & 9 & 10 & 11 & 12 & 13 & 14 & \text { Pr. } & \text { Fr. }\end{array}$

CF Caricion ferrugineae

Cerastium subtriflorum

Knautia longifolia

Malaxis monophyllos

Lathyrus occidentalis var. montanus

Serratula macrocephala

SV Seslerietalia coeruleae

Galium anisophyllum

Juncus monanthos

Potentilla crantzii

Ranunculus carinthiacus

Helictotrichon parlatorei

Geranium argenteum

Saussurea discolor

Leontopodium alpinum

Thesium alpinum

ES Elyno-Seslerietea

Aster bellidiastrum

Polygonum viviparum

Betonica alopecuros

Alchemilla fallax

Alchemilla alpigena

Anemone narcissiflora

Carex sempervirens

Lotus alpinus

Sesleria caerulea

Phyteuma orbiculare

Homogyne discolor

Bartsia alpina

Myosotis alpestris

Rhinanthus glacialis

Hieracium villosum

Campanula witasekiana

Ranunculus montanus

Thymus praecox subsp. polytrichus

Scabiosa lucida

Helianthemum nummularium subsp. grandiflorum

Linum julicum

Gentianella anisodonta

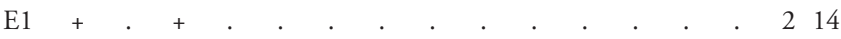

$\mathrm{E} 1$. . . . . 1 . . . . . . . 17

$\mathrm{E} 1$. . . . . . 1 . . . . . . 17

$\mathrm{E} 1$. . . . . . . . . + . . . 17

E1

$\begin{array}{llllllllllllllllllllll} & \text { E1 } & 1 & 1 & 1 & 1 & . & . & . & . & . & . & . & + & . & . & 5 & 36 \\ \text { E1 } & + & + & + & . & . & + & . & . & . & . & . & . & . & . & 4 & 29 \\ \text { E1 } & + & + & . & + & . & . & . & . & . & . & . & . & . & . & . & & \\ \text { E1 } & + & + & + & . & . & . & . & . & + & . & . & . & . & . & 4 & 29 \\ \text { E1 } & . & + & + & . & . & . & . & . & . & . & . & . & . & . & . & & 3 & 21 \\ \text { E1 } & . & . & . & + & . & . & . & . & . & . & . & . & . & . & . & 2 & 14 \\ \text { E1 } & . & . & . & . & . & . & . & . & . & . & . & . & . & . & . & 1 & 7 \\ \text { E1 } & . & . & . & . & . & . & . & . & . & . & . & 1 & . & . & 1 & 7 \\ \text { E1 } & . & . & . & . & . & . & . & . & . & . & . & . & . & . & 1 & 7 \\ \end{array}$

\section{Nardion strictae}

Potentilla erecta

Coeloglossum viride

\begin{tabular}{|c|c|c|c|c|c|c|c|c|c|c|c|c|c|c|}
\hline E1 & 1 & + & $\cdot$ & & & 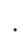 & & & & + & & & & \\
\hline E1 & + & + & + & 1 & & . & 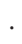 & 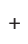 & & . & 1 & + & . & 7 \\
\hline E1 & + & 1 & 1 & 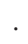 & + & . & & & & 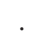 & & & & \\
\hline E1 & 1 & + & 1 & + & + & . & & & & 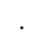 & & & & \\
\hline E1 & + & + & + & 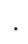 & 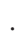 & + & & & & 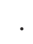 & . & . & & \\
\hline $\mathrm{E}$ & . & . & . & . & . & . & . & + & & . & $\mathrm{r}$ & + & 1 & 4 \\
\hline & + & + & + & + & . & . & . & & & . & . & 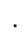 & & 4 \\
\hline & + & 1 & 1 & . & . & . & + & r. & $\cdot$ & . & . & . & . & \\
\hline & + & . & . & $\cdot$ & . & . & . & . & . & . & 2 & . & 1 & כ \\
\hline & . & . & . & $\cdot$ & . & . & . & + & . & . & . & + & + & 3 \\
\hline & . & + & . & . & . & . & 1 & . & r. & . & ${ }^{\circ}$ & 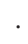 & . & \\
\hline & . & + & . & . & . & . & 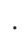 & $\theta^{\circ}$ & 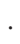 & . & ${ }^{\circ}$ & . & + & \\
\hline & . & . & . & . & . & . & + & $r^{\prime}$ & 1 & . & $\cdot$ & . & 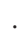 & \\
\hline & . & . & . & $\cdot$ & . & . & . & 1 & 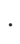 & . & ${ }^{\circ}$ & 1 & . & \\
\hline & . & . & . & $\cdot$ & . & . & . & 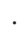 & 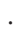 & + & . & . & + & \\
\hline & . & . & . & $\cdot$ & . & . & . & + & $\cdot$ & . & $\cdot$ & . & . & 1 \\
\hline & . & . & . & . & . & . & . & + & $\cdot$ & . & . & . & . & 1 \\
\hline & . & . & . & . & . & . & $\cdot$ & . & r & . & + & . & . & 1 \\
\hline & . & . & . & . & . & . & . & . & 1 & . & . & . & . & 1 \\
\hline & . & . & . & . & . & . & . & . & . & + & . & . & . & 1 \\
\hline & . & . & . & . & . & . & . & $\cdot$ & & . & . & 1 & . & 1 \\
\hline & . & . & . & & . & . & . & . & . & . & . & + & . & 1 \\
\hline
\end{tabular}

JT Juncetea trifidi

Campanula scheuchzeri

Anthoxanthum nipponicum

E1

17

LV Loiseleurio-Vaccinietea

Arctostaphylos alpinus

E1

E1

AC Arabidetalia caeruleae

Soldanella alpina

Potentilla brauneana

Trifolium pallescens

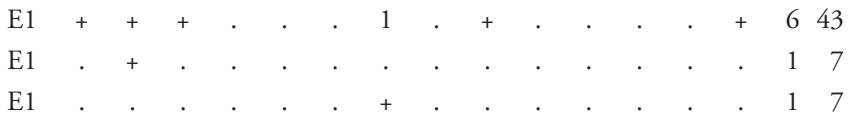


Number of relevé (Zaporedna številka popisa) $\quad \begin{array}{lllllllllllllllll}1 & 1 & 2 & 3 & 4 & 5 & 6 & 7 & 8 & 9 & 10 & 11 & 12 & 13 & 14 & \text { Pr. Fr. }\end{array}$

TR Thlaspietea rotundifolii

Adenostyles glabra

Festuca nitida

Heliosperma alpestre

Valeriana montana

Biscutella laevigata

Saxifraga aizoides

Silene vulgaris subsp. glareosa

Pimpinella alpina

Dryopteris villarii

Astrantia carniolica

Gymnocarpium robertianum

Campanula cochleariifolia

Hieracium bifidum

Athamanta cretensis

\begin{tabular}{|c|c|c|c|c|c|c|c|c|}
\hline 1 & + & 1 & 1 & + & 1 & & & \\
\hline E1 & + & + & + & . & . & . & 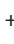 & \\
\hline E1 & . & + & . & 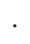 & 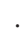 & . & 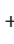 & \\
\hline E1 & . & . & . & 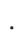 & ${ }^{\circ}$ & 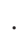 & & \\
\hline E1 & + & . & . & & . & & & \\
\hline E1 & . & . & . & 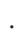 & . & 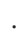 & 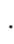 & . \\
\hline E1 & + & . & . & ${ }^{\circ}$ & . & 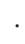 & 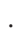 & . \\
\hline E1 & . & . & . & 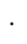 & + & . & 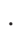 & . \\
\hline E1 & . & . & . & 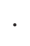 & . & 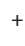 & 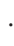 & . \\
\hline E1 & . & . & . & 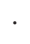 & . & 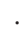 & & + \\
\hline E1 & . & . & . & 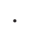 & . & 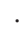 & & + \\
\hline E1 & . & . & . & & . & 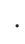 & & . \\
\hline E1 & . & . & $\cdot$ & & & & & . \\
\hline E1 & . & . & & . & & & & \\
\hline
\end{tabular}

PS Physoplexido-Saxifragion petraeae

Paederota lutea

E1

Saxifraga crustata

PC Potentilletalia caulescentis

Valeriana saxatilis

Cy Cystopteridion fragilis

Cystopteris fragilis

Cystopteris regia

AT Asplenietea trichomanis

Valeriana tripteris

Asplenium viride

CD Caricetalia davallianae

Parnassia palustris

Tofieldia calyculata

Carex capillaris

Pinguicula alpina

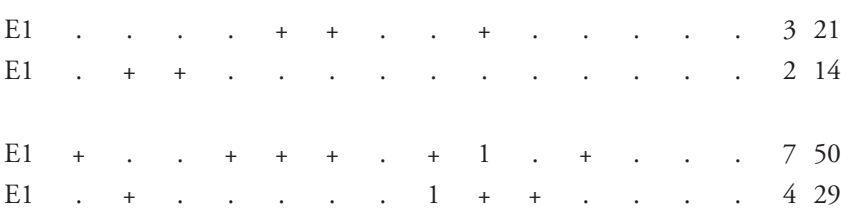

PoT Poo alpinae-Trisetetalia

Trollius europaeus

Cardaminopsis halleri

Pimpinella major subsp. rubra

\begin{tabular}{|c|c|c|c|c|c|c|c|c|c|}
\hline 1 & + & . & . & + & $+\quad+$ & & & & \\
\hline+ & . & . & . & & . & & & & \\
\hline & . & . & . & - & & & & & \\
\hline & . & & & & r & & & & \\
\hline
\end{tabular}

MA Molinio-Arrbenatheretea

Angelica sylvestris

Dactylis glomerata

Trifolium pratense

Deschampsia cespitosa

Lathyrus pratensis

Vicia cracca

Leontodon hispidus

Galium album

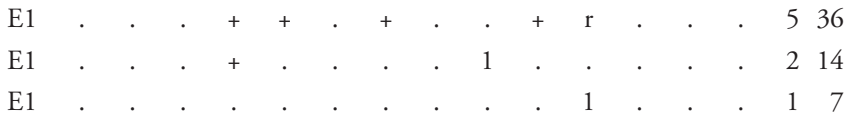

FB Festuco-Brometea

Gymnadenia conopsea

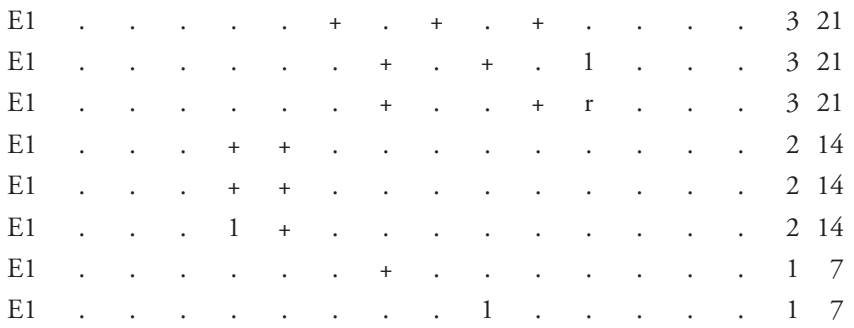

TG Trifolio-Geranietea

Trifolium alpestre

Bupleurum longifolium

E1

SS Sambuco-Salicion capreae

Urtica dioica

E1 
Number of relevé (Zaporedna številka popisa)

Sorbus aucuparia

$\mathrm{EP}$

\section{Erico-Pinetea}

Rubus saxatilis

Cirsium erisithales

Carex ornithopoda

Buphthalmum salicifolium

Calamagrostis varia

Aquilegia nigricans

Peucedanum austriacum subsp. rablense

VP

\section{Vaccinio-Piceetea}

Luzula sylvatica

Polystichum lonchitis

Rosa pendulina

Solidago virgaurea

Gentiana asclepiadea

Dryopteris expansa

Aposeris foetida

Vaccinium myrtillus

Maianthemum bifolium

Picea abies

Clematis alpina

Vaccinium vitis-idaea

Larix decidua

Pyrola minor

Abies alba

Calamagrostis arundinacea

Hieracium murorum

Lonicera caerulea

Melampyrum sylvaticum

Luzula luzuloides

Pyrola rotundifolia

Huperzia selago

\section{TA Tilio-Acerion}

Thalictrum aquilegiifolium

Chrysosplenium alternifolium

Acer pseudoplatanus

Adoxa moschatellina

$\mathrm{AF}$

\section{Aremonio-Fagion}

Cardamine enneaphyllos

Knautia drymeia

Rhamnus fallax

FS Fagetalia sylvaticae

Epilobium montanum

Dryopteris filix-mas

Galeobdolon flavidum

Paris quadrifolia

Galium laevigatum

Lilium martagon

Daphne mezereum

Lathyrus vernus

Melica nutans
E2a

E1

E1

E1

E1

E1

E1

E1

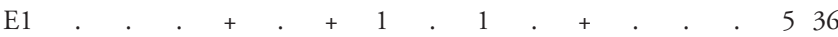

$\mathrm{E} 1++.++.+429$

$\mathrm{E} 1 .+.+2+2++536$

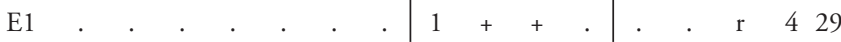

E1 . . . . . 1 . + + . . 321

$\mathrm{E} 1$. . . . + . . . . + . . . 214

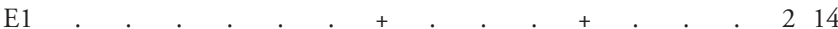

E1 $1+1.214$

E1 . . . . + + . . 214

E2a $. r . r .214$

$\mathrm{E} 2 \mathrm{a} \ldots+\ldots+214$

E1 $1 \ldots . .17$

$\mathrm{E} 2+.+.+.+17$

$\mathrm{E} 1+\ldots+.+17$

$\mathrm{E} 2 .+\mathrm{r} . .5 .617$

$\mathrm{E} 1 .+. .+. . .517$

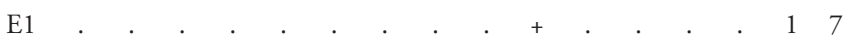

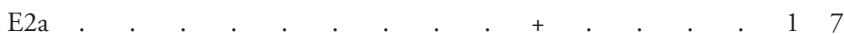

E1 . . . . . . + . . . 17

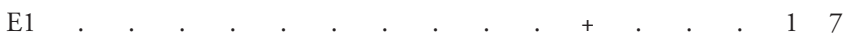

$\mathrm{E} 1 .+.5 .+.+17$

E1 . . . . . . . . . . . + 17

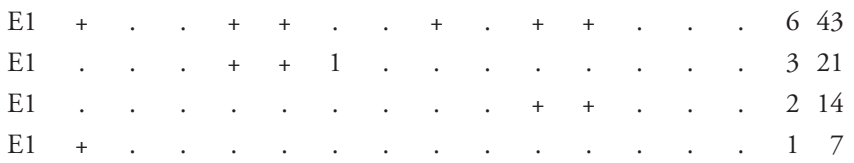

$\mathrm{E} 1+++214$

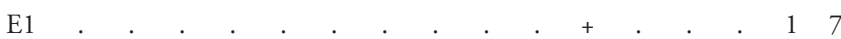

$\mathrm{E} 2 \ldots \mathrm{r} . . .517$

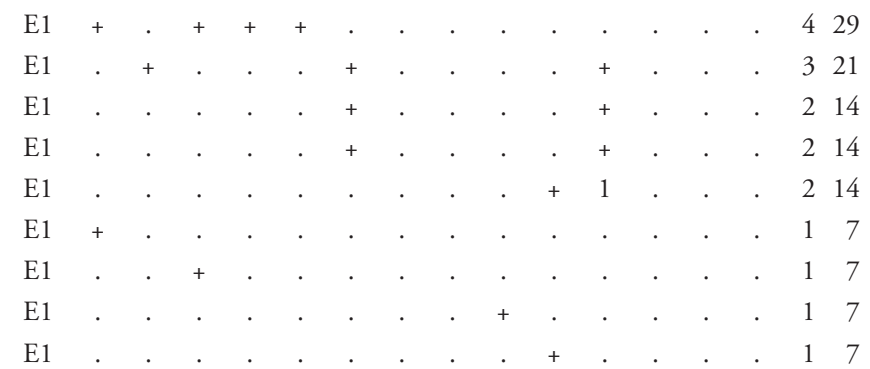


Number of relevé (Zaporedna številka popisa)

Mercurialis perennis

Poa nemoralis

QF Querco-Fagetea

Anemone nemorosa

Primula veris subsp. columnae

Convallaria majalis

O Other species (Druge vrste)

Festuca sp.

Alchemilla sp.

Vicia sp.

Minuartia sp.

Hieracium sp.

ML Mosses and lichens (Mahovi in lišaji)

Ctenidium molluscum

Rhytidiadelphus triquetrus

Tortella sp.

Pseudoleskeella catenulata

Marchantia polymorpha

Dicranum scoparium

Schistidium apocarpum

Tortella tortuosa
E1

E1

E1 . . . . . . . . + . . . . 214

$\mathrm{E} 1$. . . . + . . . . . . . 17

$\mathrm{E} 1$. . . . . . . . . 1 . . . 17

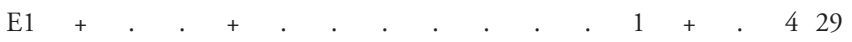

$\mathrm{E} 1$. . . . . + . . . . . . . 17

$\mathrm{E} 1$. . . . . . . . . . $\quad$ r $. \quad . \quad$. 17

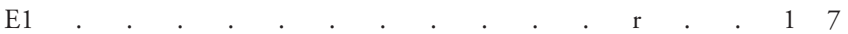

E1 . . . . . . . . . . . . . . . 17

$\mathrm{E} 0$. . . . . . $2.4+\ldots 21$

$\mathrm{E} 0$. . . . . . $1+.214$

E0 . . . . . . . . . . ++214

$\mathrm{E} 1 . . \quad . \quad . \quad . \quad 1 \quad . \quad . \quad . \quad . \quad 17$

$\mathrm{E} 0$. . . . . . . . . . . 17

$\mathrm{E} 0$. . . . . . . . . . 17

$\mathrm{E} 0$. . . . . . . . . . . . 17

\section{Legend - Legenda}

Pr. Presence (number of relevés in which the species is presented) - število popisov, v katerih se pojavlja vrsta

Fr. Frequency in \% - frekvenca $v \%$

E2a Lower shrub layer - spodnja grmovna plast

ID Igor Dakskobler

BS Boštjan Surina

TW Tone Wraber

A Limestone - apnenec

D Dolomite-dolomit

Gr Gravel - grušč

Li Lithosol - kamnišče

Re Rendzina - rendzina 
Table 3: Laserpitio peucedanoidis-Salicetum waldstenianae var. geogr. Hypericum grisebachii T. Wraber (Hyperico grisebachii-Salicetum waldsteinianae T. Wraber), the Snežnik Mts.

Tabela 3: Laserpitio peucedanoidis-Salicetum waldstenianae var. geogr. Hypericum grisebachii T. Wraber (Hyperico grisebachii-Salicetum waldsteinianae T. Wraber), Snežniško pogorje

\begin{tabular}{|c|c|c|c|c|c|c|c|c|}
\hline & \multicolumn{2}{|l|}{ Number of relevé (Zaporedna številka popisa) } & 1 & 2 & 3 & 4 & & \\
\hline & \multicolumn{2}{|c|}{ Database number of relevé (Delovna številka popisa) } & 265160 & 265163 & 265162 & 265161 & & \\
\hline & \multicolumn{2}{|l|}{ Author of the relevé (Avtor popisa) } & TW & TW & TW & TW & & \\
\hline & \multicolumn{2}{|l|}{ Elevation in $\mathrm{m}$ (Nadmorska višina $\mathrm{v} \mathrm{m})$} & 1580 & 1610 & 1620 & 1680 & & \\
\hline & \multicolumn{2}{|l|}{ Aspect (Lega) } & $\mathrm{N}$ & $\mathrm{N}$ & $\mathrm{W}$ & NWW & & \\
\hline & \multicolumn{2}{|l|}{ Slope in degrees (Nagib v stopinjah) } & 25 & 10 & 10 & 25 & & \\
\hline & \multicolumn{2}{|l|}{ Parent material (Matična podlaga) } & A & A & $\mathrm{A}$ & $\mathrm{A}$ & & \\
\hline & \multicolumn{2}{|l|}{ Soil (Tla) } & $\mathrm{R}$ & $\mathrm{R}$ & $\mathrm{R}$ & $\mathrm{R}$ & & \\
\hline & \multirow{2}{*}{\multicolumn{2}{|c|}{$\begin{array}{l}\text { Cover of shrub and herb layer in \% } \\
\text { (Zastiranje grmovne in zeliščne plasti v \%) } \\
\text { Number of species (Število vrst) }\end{array}$}} & 100 & 100 & 100 & 100 & & \\
\hline & & & 26 & 32 & 23 & 32 & & \\
\hline & Relevé area (Velikost popisne ploskve) & \multirow[t]{3}{*}{$\mathrm{m}^{2}$} & 20 & 50 & 20 & 60 & & \\
\hline & Date of taking relevé (Datum popisa) & & $7 / 26 / 1994$ & $8 / 10 / 1994$ & $8 / 24 / 1997$ & $8 / 9 / 1994$ & & \\
\hline & Locality (Nahajališče) & & Veliki Snežnik & Veliki Snežnik-Čelo & Kindlerjev vrh & Veliki Snežnik & & \\
\hline & Quadrant (Kvadrant) & & $0452 / 2$ & $0452 / 2$ & $0452 / 2$ & $0452 / 2$ & & \\
\hline & Coordinate GK Y (D-48) & $\mathrm{m}$ & 457366 & 457554 & 457692 & 457087 & & \\
\hline & Coordinate GK X (D-48) & $\mathrm{m}$ & 5049869 & 5049898 & 5049318 & 5049560 & & \\
\hline & \multicolumn{6}{|c|}{ Diagnostic species of the association (Diagnostične vrste asociacije) } & & Fr. \\
\hline BA & Salix waldsteiniana & $\mathrm{E} 2 \mathrm{a}$ & 4 & 5 & 5 & 4 & 4 & 100 \\
\hline $\mathrm{MuA}$ & Hypericum richeri subsp. grisebachii & E1 & 1 & 1 & + & 1 & & 100 \\
\hline $\mathrm{CA}$ & Laserpitium peucedanoides & E1 & 1 & 1 & . & . & 2 & \\
\hline CF & Carex ferruginea & E1 & 2 & 1 & . & . & 2 & 50 \\
\hline $\mathrm{CA}$ & Pulsatilla alpina subsp. austroalpina & E1 & 1 & 1 & . & . & 2 & 50 \\
\hline VP & Homogyne sylvestris & E1 & . & 1 & + & . & 2 & 50 \\
\hline \multirow{16}{*}{$\mathrm{MuA}$} & \multicolumn{8}{|l|}{ Mulgedio-Aconitetea } \\
\hline & Geranium sylvaticum & E1 & 1 & 1 & 1 & 1 & 4 & 100 \\
\hline & Veratrum album subsp. album & E1 & 1 & 1 & . & 1 & 3 & 75 \\
\hline & Heracleum sphondylium subsp. montanum & E1 & + & + & . & + & 3 & 75 \\
\hline & Viola biflora & E1 & . & + & 1 & 1 & 3 & 75 \\
\hline & Aconitum lycoctonum s. lat. (A. lupicida) & E1 & . & 1 & + & . & 2 & 50 \\
\hline & Allium victorialis & E1 & . & + & + & . & 2 & 50 \\
\hline & Crepis paludosa & E1 & . & + & + & . & 1 & 50 \\
\hline & Silene vulgaris subsp. antelopum & E1 & . & 1 & . & + & 2 & 50 \\
\hline & Doronicum austriacum & E1 & . & . & 1 & 2 & 2 & 50 \\
\hline & Saxifraga rotundifolia & E1 & . & . & 1 & + & 2 & 50 \\
\hline & Adenostyles alliariae & E1 & . & . & . & 2 & 1 & 25 \\
\hline & Cicerbita alpina & E1 & . & . & . & 1 & 1 & 25 \\
\hline & Rumex arifolius & E1 & . & . & . & 1 & 1 & 25 \\
\hline & Senecio ovatus & E1 & . & . & . & 2 & 1 & 25 \\
\hline & Tephroseris longifolia & E1 & . & . & . & 1 & 1 & 25 \\
\hline \multirow[t]{2}{*}{ RE } & \multicolumn{8}{|l|}{ Rhododendro hirsuti-Ericetalia carneae } \\
\hline & Rhododendron hirsutum & $\mathrm{E} 2 \mathrm{a}$ & + & . & . & . & 1 & 25 \\
\hline \multirow[t]{3}{*}{$\mathrm{CA}$} & \multicolumn{8}{|l|}{ Caricion austroalpinae } \\
\hline & Gentiana lutea subsp. symphyandra & E1 & + & . & . & . & 1 & 25 \\
\hline & Koeleria eriostachya & E1 & . & . & . & + & 1 & 25 \\
\hline \multirow[t]{8}{*}{ ES } & \multicolumn{8}{|l|}{ Elyno-Seslerietea } \\
\hline & Campanula witasekiana & E1 & + & + & . & 1 & 3 & 75 \\
\hline & Rhinanthus glacialis & E1 & . & + & . & . & 1 & 25 \\
\hline & Myosotis alpestris & E1 & . & . & + & . & 1 & 25 \\
\hline & Homogyne discolor & E1 & . & . & . & 2 & 1 & 25 \\
\hline & Bartsia alpina & E1 & . & . & . & + & 1 & 25 \\
\hline & Phyteuma orbiculare & E1 & . & . & . & + & 1 & 25 \\
\hline & Polygonum viviparum & E1 & . & . & . & + & 1 & 25 \\
\hline
\end{tabular}


Number of relevé (Zaporedna številka popisa)

2

NS Nardion strictae

Coeloglossum viride

E1

AC Arabidetalia caeruleae

Soldanella alpina

E1

TR Thlaspietea rotundifolii

Festuca nitida

Rumex scutatus

Adenostyles glabra

Dryopteris villarii

Heliosperma alpestre

\section{E1}

E1

E1

E1

E1

AT Asplenietea trichomanis

Asplenium viride

Valeriana tripteris

PoT Poo alpinae-Trisetetalia

Trollius europaeus

Festuca nigrescens

MA Molinio-Arrbenatheretea

Deschampsia cespitosa

Trifolium pratense

FB Festuco-Brometea

Gymnadenia conopsea

TG Trifolio-Geranietea

Lilium carniolicum

SS Sambuco-Salicion capreae

Rubus idaeus

EP Erico-Pinetea

Cirsium erisithales

Rubus saxatilis

Calamagrostis varia

Buphthalmum salicifolium

Pinus mugo

VP Vaccinio-Piceetea

Rosa pendulina

Aposeris foetida

Polystichum lonchitis

Homogyne alpina

Solidago virgaurea

AF Aremonio-Fagion

Cardamine enneaphyllos

FS Fagetalia sylvaticae

Mercurialis perennis

Daphne mezereum

Galeobdolon flavidum

Actaea spicata

Poa nemoralis

Myosotis sylvatica agg.

QF Querco-Fagetea

Anemone nemorosa

$\mathrm{O}$ Other species (Druge vrste)

Alchemilla sp.
E1

E1

E1

E1

E1

E1

E1

E1

E2a

E1 1

E1

E1

E1

E2a

E2a

E1

E1

E1

E1

E1

\section{E1}

E2a

E1

E1

E1

E1

E1

E1

1

2

$+$

.
125

4100

$\cdot$
1
$\cdot$
+
$\cdot$
$\cdot$
$\cdot$
+
+
+
+

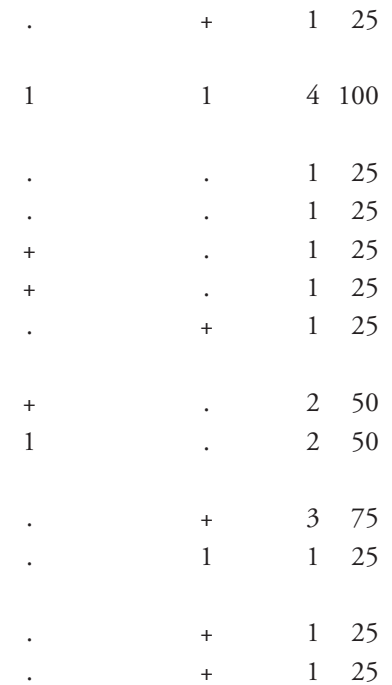

125

125

125

-

4100

375

250

125

125

275

250

250

125

125

125

250

125

125

125

125

125

375

125

\section{Legend - Legenda}

Pr. Presence (number of relevés in which the species is presented) število popisov, v katerih se pojavlja vrsta

Fr. Frequency in $\%$ - frekvenca $v \%$
E2a Lower shrub layer - spodnja grmovna plast TW Tone Wraber

A Limestone - apnenec

Re Rendzina - rendzina 
Table 4 (Tabela 4): Heliospermo-Rhododendretum hirsuti, Homogyno sylvestris-Salicetum glabrae, Rhododendro hirsuti-Salicetum appendiculatae

\section{Number of relevé (Zaporedna številka popisa)}

Database number of relevé (Delovna številka popisa)

Author of the relevé (Avtor popisa)

Elevation in $\mathrm{m}$ (Nadmorska višina $\mathrm{v} \mathrm{m})$

\section{Aspect (Lega)}

Slope in degrees (Nagib v stopinjah)

Parent material (Matična podlaga)

Soil (Tla)

Stoniness in \% (Kamnitost v \%)

Cover of tree layer in \% (Zastiranje drevesne plasti v \%) E3

Cover of shrub layer in \% (Zastiranje grmovne plasti v \%) E2

Cover of herb layer in \% (Zastiranje zeliščne plasti v \%) $\quad$ E1

Cover of moss layer in \% (Zastiranje mahovne plasti v \%) E0

Number of species (Število vrst)

Relevé area (Velikost popisne ploskve)

Date of taking relevé (Datum popisa)

Locality (Nahajališče)

Quadrant (Kvadrant)

Coordinate GK Y (D-48)

Coordinate GK X (D-48)

Diagnostic species of the associations (Diagnostične vrste asociacij)

\section{$\begin{array}{llllllllll}1 & 2 & 3 & 4 & 5 & 6 & 7 & 8 & 9 & 10\end{array}$

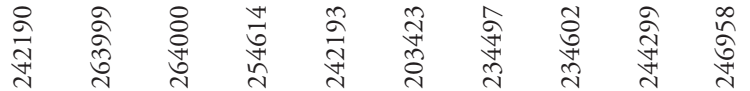

ID ID ID ID ID ID ID ID ID ID

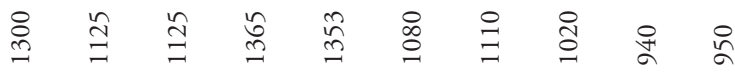

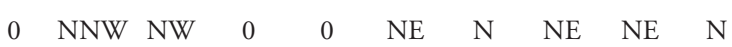

$\begin{array}{llllllllll}0 & 45 & 50 & 0-5 & 0-10 & 25 & 45 & 30 & 35 & 45\end{array}$

A A A $\quad$ DA A DA D Gr D DA

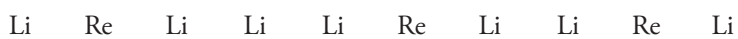

$\begin{array}{llllllllll}90 & 30 & 10 & 90 & 90 & . & . & 30 & 20 & 30\end{array}$

$\begin{array}{cccccccccc}7 & \cdot & \cdot & \cdot & \cdot & \cdot & \cdot & \cdot & \cdot & \cdot\end{array}$

$\begin{array}{llllllllll}30 & 40 & 40 & 30 & 30 & 80 & 60 & 40 & 60 & 70\end{array}$

$\begin{array}{llllllllll}20 & 40 & 10 & 30 & 20 & 5 & 10 & 5 & 5 & 10\end{array}$

$\begin{array}{llllllllll}41 & 31 & 28 & 45 & 33 & 43 & 57 & 37 & 27 & 26\end{array}$

$\begin{array}{lllllllllll}\mathrm{m}^{2} & 100 & 50 & 50 & 50 & 100 & 50 & 50 & 50 & 100 & 10\end{array}$

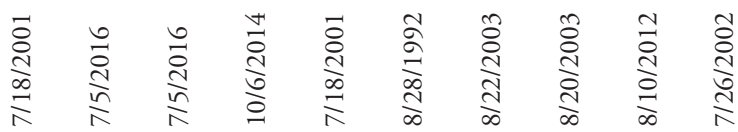

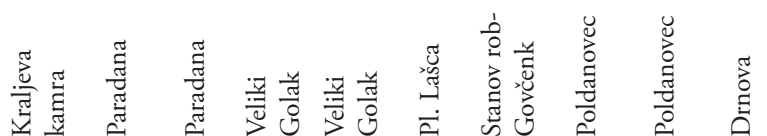

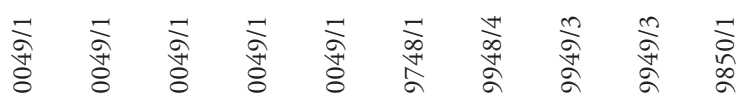

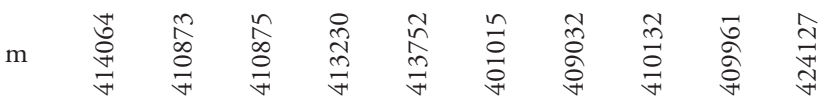

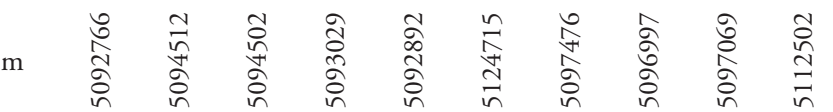

EP

BA

Cy

CF Heliosperma pusillum

CD Carex capillaris

EP Rhodothamnus chamaecistus

OE Carex atrata

AC Salix retusa

MuA Salix glabra

EP Calamagrostis varia

ES Sesleria caerulea

EP Erica carnea

VP Homogyne sylvestris

CF Carex ferruginea

AF Cyclamen purpurascens

ES Betonica alopecuros

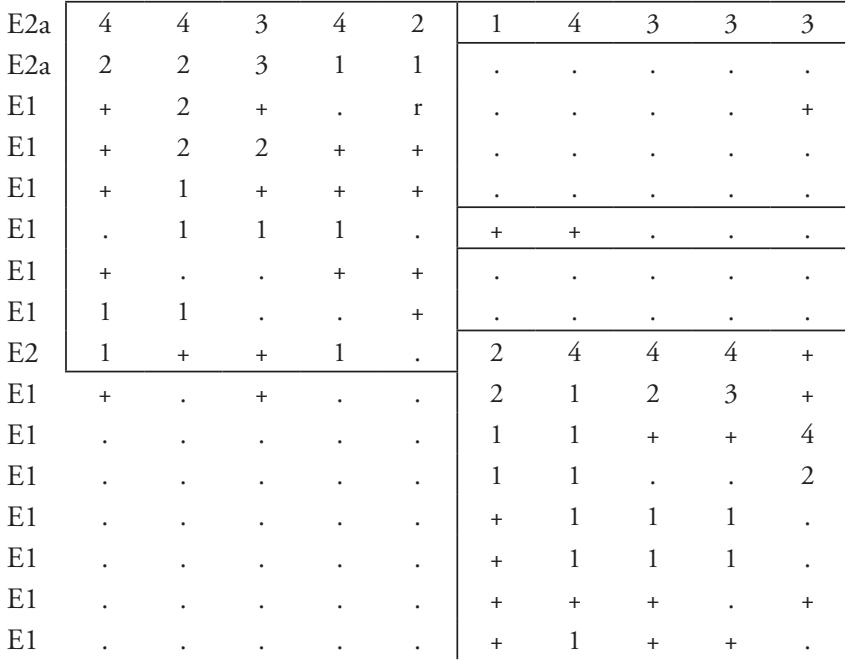




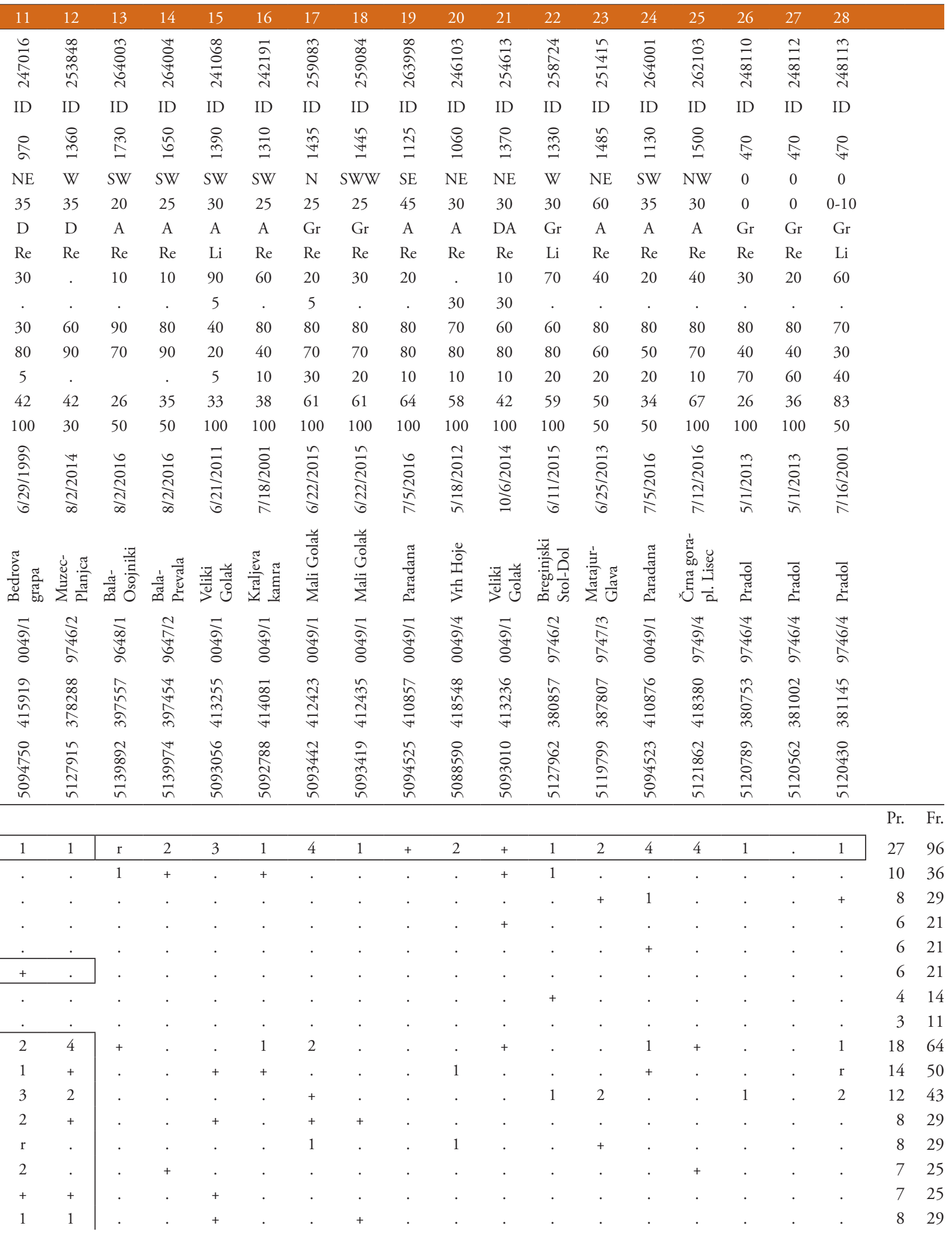




\begin{tabular}{|c|c|c|c|c|c|c|c|c|c|c|c|c|}
\hline & Number of relevé (Zaporedna številka popisa) & & 1 & 2 & 3 & 4 & 5 & 6 & 7 & 8 & 9 & 10 \\
\hline QP & Ostrya carpinifolia & $\mathrm{E} 2 \mathrm{~b}$ & . & . & . & . & . & + & . & + & + & . \\
\hline QP & Ostrya carpinifolia & $\mathrm{E} 2 \mathrm{a}$ & . & . & . & . & . & . & . & . & + & + \\
\hline QP & Ostrya carpinifolia & E1 & . & . & . & . & . & . & . & . & . & 1 \\
\hline $\mathrm{AF}$ & Knautia drymeia & E1 & . & . & . & . & . & . & 1 & + & + & . \\
\hline TR & Astrantia carniolica & E1 & . & . & . & . & . & 1 & 1 & + & . & . \\
\hline $\mathrm{MuA}$ & Salix appendiculata & $\mathrm{E} 2 \mathrm{~b}$ & + & . & . & . & . & . & . & + & 1 & . \\
\hline $\mathrm{MuA}$ & Salix appendiculata & E2a & + & 1 & . & 1 & + & + & . & . & . & 1 \\
\hline PC & Paederota lutea & E1 & 1 & + & 1 & + & 1 & . & 1 & . & . & . \\
\hline $\mathrm{AF}$ & Cardamine trifolia & E1 & . & . & . & + & . & . & . & . & . & $\cdot$ \\
\hline AT & Polypodium vulgare & E1 & . & . & . & . & + & . & . & . & . & $\cdot$ \\
\hline TA & Dryopteris remota & E1 & . & . & . & . & . & . & . & . & . & . \\
\hline TA & Phyllitis scolopendrium & E1 & . & . & . & . & . & . & . & . & . & $\cdot$ \\
\hline \multirow[t]{5}{*}{$\mathrm{BA}$} & Betulo-Alnetea viridis & & & & & & & & & & & \\
\hline & Ribes alpinum & E2a & . & . & $\cdot$ & . & . & . & . & . & . & . \\
\hline & Sorbus chamaemespilus & E2 & . & . & . & . & . & . & . & . & . & $\cdot$ \\
\hline & Juniperus alpina & E2a & . & . & . & . & . & . & . & . & . & $\cdot$ \\
\hline & Alnus viridis & E2a & . & . & . & . & . & . & . & . & . & $\cdot$ \\
\hline \multicolumn{13}{|c|}{ MuA Mulgedio-Aconitetea } \\
\hline & Viola biflora & E1 & . & 1 & 1 & + & 1 & . & . & . & . & . \\
\hline & Veratrum album subsp. lobelianum & E1 & . & . & $\cdot$ & . & . & . & . & . & + & . \\
\hline & Athyrium filix-femina & E1 & . & . & $\cdot$ & . & . & . & . & . & . & . \\
\hline & Geranium sylvaticum & E1 & . & . & . & . & . & . & . & . & . & . \\
\hline & Polygonatum verticillatum & E1 & + & . & . & . & . & . & . & . & . & . \\
\hline & Ranunculus platanifolius & E1 & . & . & . & . & . & . & . & . & . & . \\
\hline & Doronicum austriacum & E1 & . & . & . & . & . & . & . & . & . & . \\
\hline & Aconitum lycoctonum agg. (A. lupicida) & E1 & . & . & . & . & . & . & . & . & . & . \\
\hline & Saxifraga rotundifolia & E1 & . & . & . & . & . & . & . & . & . & . \\
\hline & Hypericum maculatum & E1 & . & . & . & . & . & . & . & . & . & . \\
\hline & Senecio cacaliaster & E1 & . & . & . & . & . & . & . & . & . & . \\
\hline & Crepis paludosa & E1 & . & . & . & . & . & . & . & + & . & . \\
\hline & Peucedanum ostruthium & E1 & . & . & . & . & . & . & . & . & . & . \\
\hline & Epilobium alpestre & E1 & . & . & . & . & . & . & . & . & . & . \\
\hline & Allium victorialis & E1 & . & . & . & . & . & . & . & . & . & . \\
\hline & Chaerophyllum hirsutum & E1 & . & . & . & . & . & . & . & . & . & . \\
\hline & Pleurospermum austriacum & E1 & . & . & $\cdot$ & . & . & . & . & . & . & . \\
\hline & Adenostyles alliariae & E1 & . & . & . & . & . & . & . & . & . & . \\
\hline & Geum rivale & E1 & . & . & . & . & . & . & . & . & . & . \\
\hline & Chaerophyllum villarsii & E1 & . & . & . & . & . & . & . & . & . & . \\
\hline & Silene dioica & E1 & . & . & . & . & . & . & . & . & . & . \\
\hline & Pedicularis hacquetii & E1 & . & . & . & . & . & . & . & . & . & . \\
\hline & Carduus personata & E1 & . & . & . & . & . & . & . & . & . & . \\
\hline & Myrrhis odorata & E1 & . & . & . & . & . & . & . & . & . & . \\
\hline & Phyteuma ovatum & E1 & . & . & . & . & . & . & . & . & . & . \\
\hline & Silene vulgaris subsp. antelopum & E1 & . & . & . & . & . & . & . & . & . & . \\
\hline \multirow[t]{2}{*}{$\mathrm{RE}$} & Rhododendro hirsuti-Ericetalia carneae & & & & & & & & & & & \\
\hline & Pinus mugo & E2 & . & . & $\cdot$ & . & + & + & . & . & . & . \\
\hline \multirow[t]{2}{*}{ CFir } & Caricion firmae & & & & & & & & & & & \\
\hline & Carex firma & E1 & . & . & . & . & . & + & + & . & . & . \\
\hline \multirow[t]{2}{*}{ CA } & Caricion austroalpinae & & & & & & & & & & & \\
\hline & Laserpitium peucedanoides & E1 & . & . & $\cdot$ & . & . & . & 1 & . & . & . \\
\hline
\end{tabular}



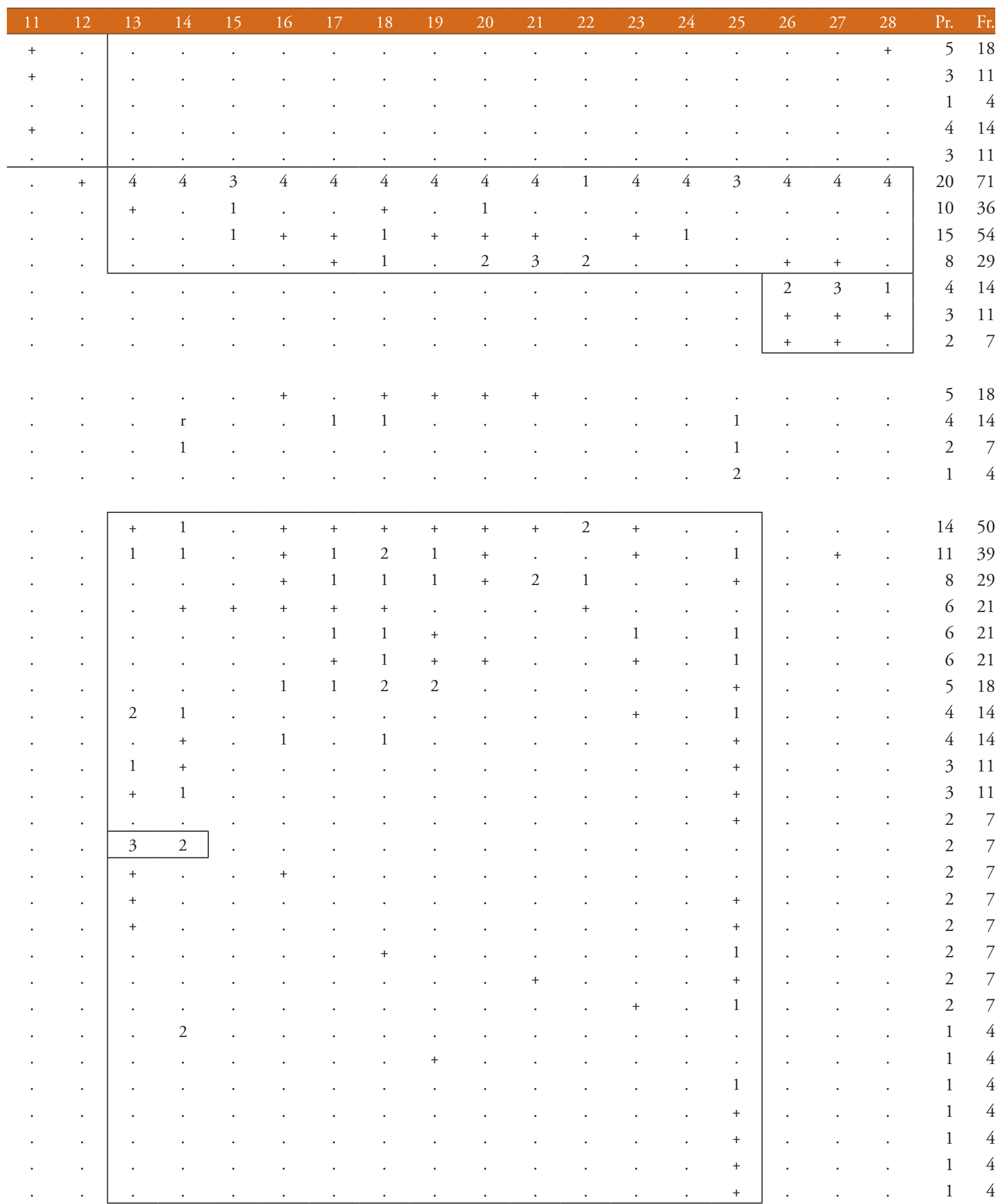
Festuca calva

Carduus crassifolius

E1

Centaurea haynaldii subsp. julica

Gentiana lutea subsp. symphyandra

E1

CF Caricion ferrugineae

Knautia longifolia

E1

Malaxis monophyllos

E1

Serratula macrocephala

E1

Lathyrus occidentalis var. montanus

E1

Cerastium subtriflorum

E1

SV Seslerietalia coeruleae

Erigeron glabratus

E1

Gentiana clusii

Leucanthemum heterophyllum

Leontopodium alpinum

Galium anisophyllum

ES Elyno-Seslerietea

Aster bellidiastrum

Campanula witasekiana

Phyteuma orbiculare

Hieracium villosum

Scabiosa lucida subsp. stricta

Polygonum viviparum

Thymus praecox subsp. polytrichus

Selaginella selaginoides

Senecio abrotanifolius

Hieracium pilosum

Carex sempervirens

Myosotis alpestris

Ranunculus montanus

Astrantia bavarica

E1

E1

E1

E1

Euphrasia salisburgensis

E1

E1

E1

E1

E1

E1

E1

E1

E1

E1

E1

E1

E1

E1

E1

NS Nardion strictae

Potentilla erecta

E1

JT Juncetea trifidi

Campanula scheuchzeri

E1

Botrychium lunaria

E1

AC Arabidetalia caeruleae

Salix serpyllifolia

E1

Soldanella minima

E1

Soldanella alpina

E1

TR Thlaspietea rotundifolii

Adenostyles glabra

Gymnocarpium robertianum

E1

Hieracium bifidum

E1

Dryopteris villarii

Festuca nitida

Molopospermum peloponnesiacum subsp. bauhinii

Campanula cochleariifolia

Campanula cespitosa

\begin{tabular}{llll} 
& 1 & 2 & 3 \\
\hline & $\cdot$ & $\cdot$ & $\cdot$ \\
& $\cdot$ & $\cdot$ & $\cdot$ \\
1 & $\cdot$ & $\cdot$ & $\cdot$ \\
& $\cdot$ & $\cdot$ &.
\end{tabular}




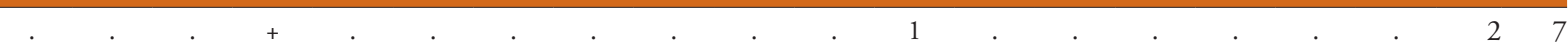
7
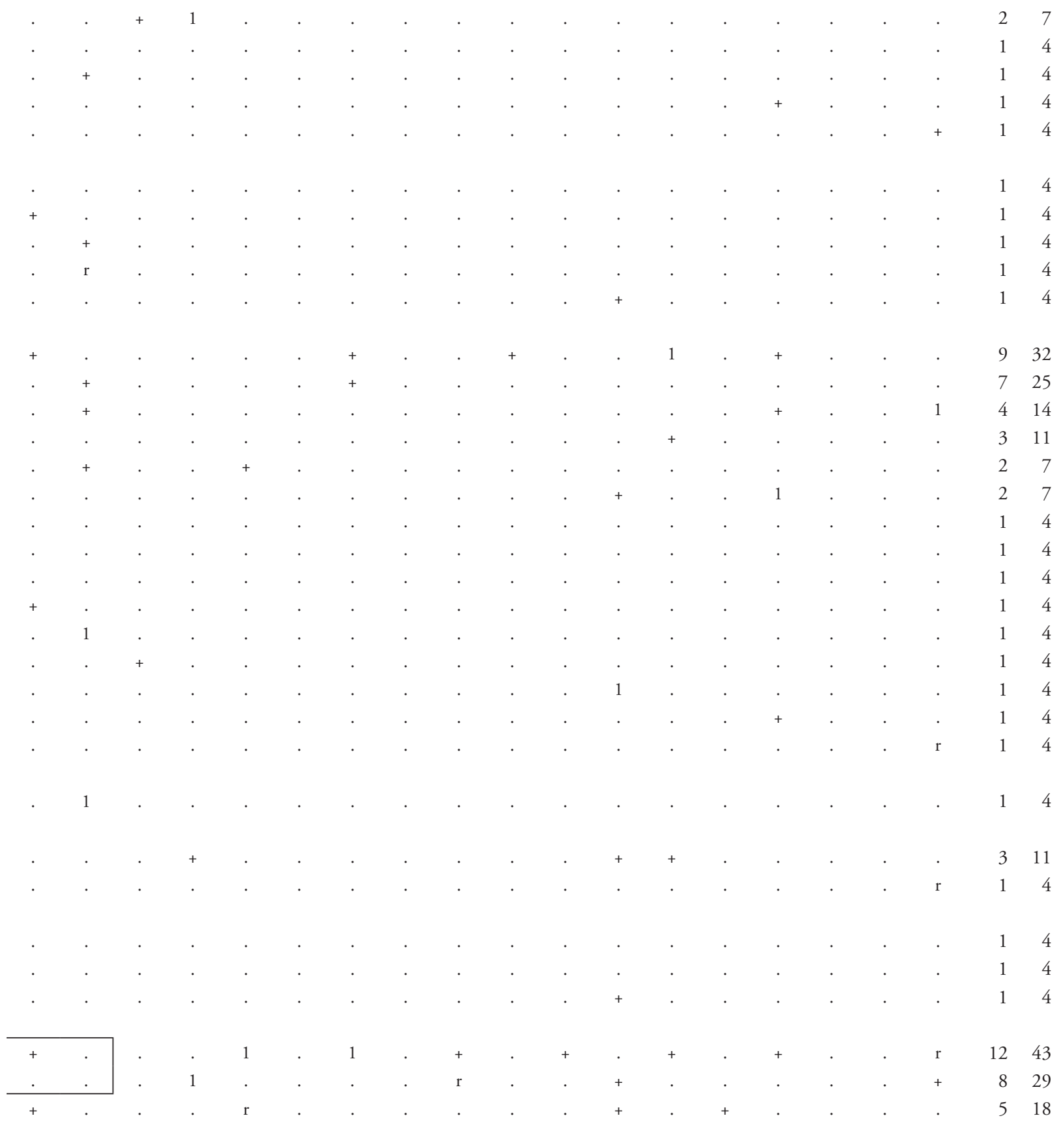
1

3

E1

E1

Rhodiola rosea

Cystopteris montana

Geranium macrorrhizum

Rumex scutatus

Heliosperma alpestre

Saxifraga caesia

Hieracium porrifolium

Aquilegia einseleana

Arabis alpina

Hieracium caesium

Ligusticum seguieri

PS Physoplexido-Saxifragion petraeae

Campanula carnica

Phyteuma scheuchzeri subsp. columnae

Saxifraga crustata

PC Potentilletalia caulescentis

Valeriana saxatilis

Primula auricula

Cy Cystopteridion fragilis

Cystopteris fragilis

Cystopteris regia

Primula carniolica

Saxifraga petraea

AT Asplenietea trichomanis

Asplenium viride

Valeriana tripteris

Asplenium ruta-muraria

Asplenium trichomanes

Moehringia muscosa

Polypodium interjectum

Hieracium glaucum

Micromeria thymifolia

Ceterach javorkeanum

CD Caricetalia davallianae

Parnassia palustris

Pinguicula alpina

Tofieldia calyculata

PoT Poo alpinae-Trisetetalia

Poa alpina

Ranunculus nemorosus

Trollius europaeus

MA Molinio-Arrhenatheretea

Dactylis glomerata

Lotus corniculatus

Leontodon hispidus

Deschampsia cespitosa

Angelica sylvestris

Trifolium pratense
E1

E1

E1

E1

E1

E1

E1

E1

E1

E1

E1

E1

E1

E1

E1

E1

E1

E1

E1

E1

E1

E1

E1

E1

E1

E1

E1

E1

E1

\section{E1}

E1

E1

E1

E1

E1

\section{E1}

E1

E1 

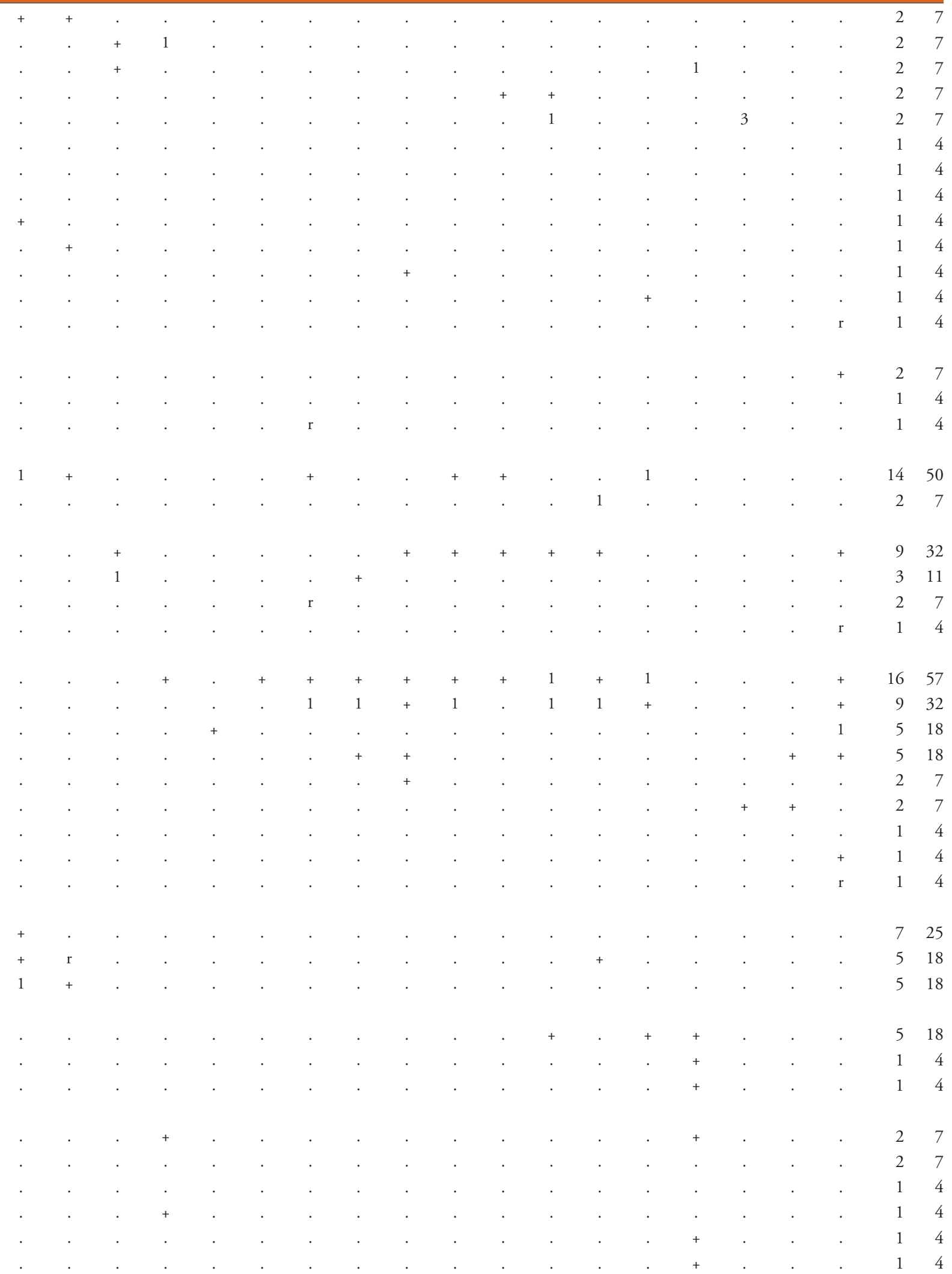
FB Festuco-Brometea

Gymnadenia conopsea

E1

Carlina acaulis

E1

Bromopsis transsilvanica

E1

Carex humilis

E1

Brachypodium rupestre

E1

Linum catharticum

E1

Galium verum

E1

Koeleria pyramidata

E1

Galium lucidum

E1

TG Trifolio-Geranietea

Grafia golaka

Lilium carniolicum

Polygonatum odoratum

Laserpitium latifolium

GU Galio-Urticetea

Urtica dioica

Lamium maculatum

SSC Sambuco-Salicion capreae, Rhamno-Prunetea

Sorbus aucuparia

Sorbus aucuparia

Sorbus aucuparia

E1

E1

E1

E1

Sorbus aucuparia

Juniperus communis

E1

A Epilobietea angustifolii

Rubus idaeus

Fragaria vesca

Sambucus racemosa

$$
\text { E3a }
$$

E2a

E1

E2a

Hypericum hirsutum

$$
\text { E2a }
$$

E1

E2

\section{Erico-Pinetea}

Rubus saxatilis

Cirsium erisithales

E1

Carex ornithopoda

Buphthalmum salicifolium

Polygala chamaebuxus

Molinia caerulea subsp. arundinacea

\section{E1}

E1

E1

E1

E1

E1

Amelanchier ovalis

E2

Allium ericetorum

E1

E1

Chamaecytisus hirsutus

Aquilegia nigricans

Pinus nigra

Leontodon incanus

Asperula aristata

E1

E1

E1

\section{cinio-Piceetea}

Clematis alpina

Rosa pendulina

\section{E2a}

Gentiana asclepiadea

Vaccinium myrtillus

Phegopteris connectilis 


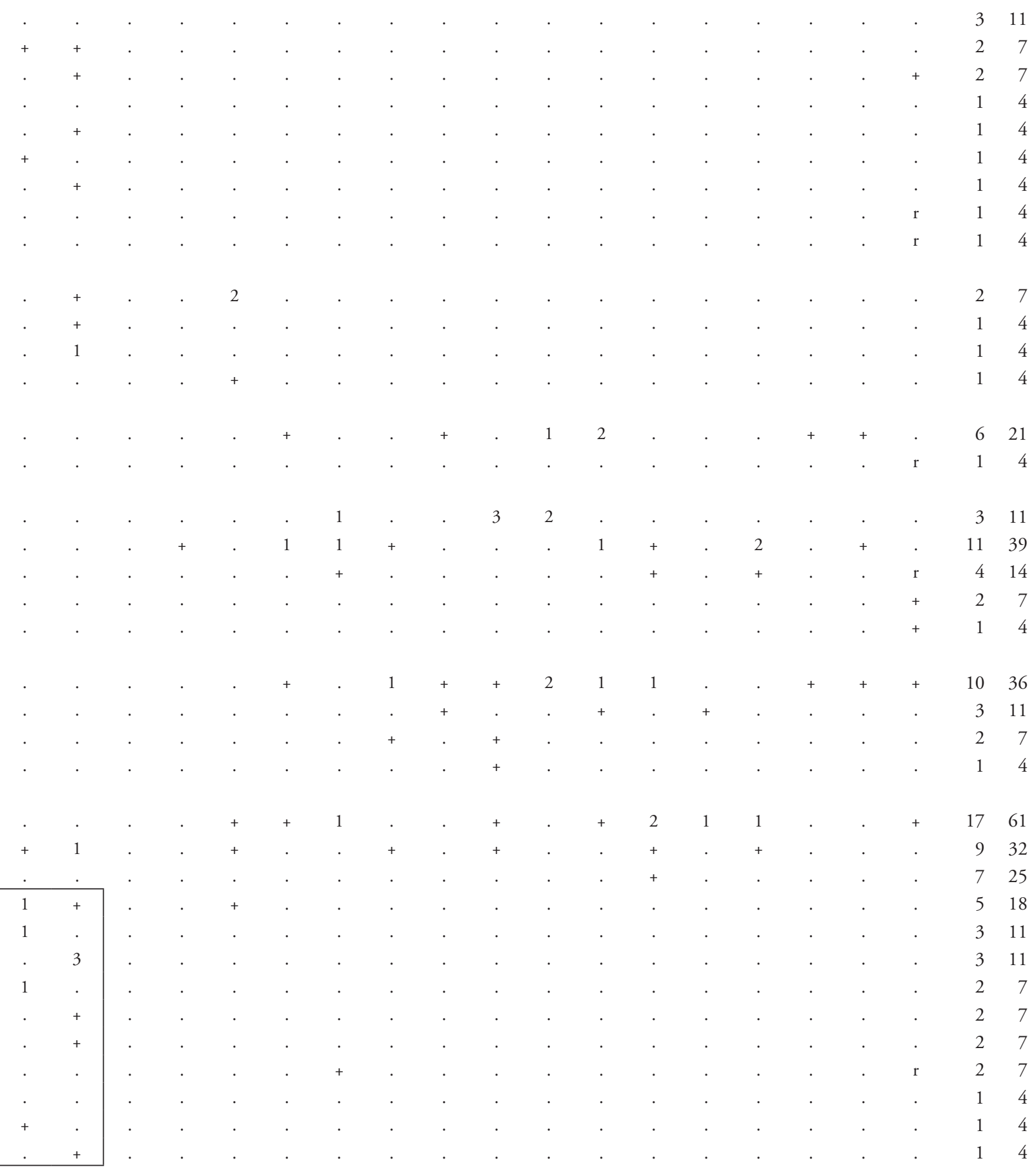

$$
\begin{array}{llllllllllllllll}
. & + & 1 & 1 & 1 & 2 & + & 2 & 1 & 2 & + & . & . & 1 & 20 & 71 \\
1 & 1 & 1 & 1 & 2 & 1 & 1 & 1 & 1 & 1 & 1 & . & . & . & 16 & 57 \\
+ & + & 1 & 1 & 1 & + & + & . & 1 & . & + & . & . & . & 13 & 46 \\
. & + & 1 & + & + & 2 & + & + & + & . & 1 & . & 3 & \mathrm{r} & 13 & 46 \\
. & 2 & 2 & 1 & 2 & 3 & + & 3 & + & . & + & . & . & . & 13 & 46
\end{array}
$$


Lonicera caerulea

Vaccinium vitis-idaea

E2a

Picea abies

E3a

Picea abies

Picea abies

Picea abies

Calamagrostis arundinacea

Solidago virgaurea

Dryopteris dilatata

Gymnocarpium dryopteris

Huperzia selago

Lycopodium annotinum

Abies alba

Abies alba

Abies alba

Pyrola rotundifolia

Calamagrostis villosa

Veronica urticifolia

Polystichum lonchitis

Aposeris foetida

Luzula sylvatica

Dryopteris expansa

Lonicera nigra

$\mathrm{E} 2 \mathrm{~b}$

E2a

E1

E1

E1

E1

E1

E1

E1

E2b

E2a

E1

E1

E1

E1

E1

E1

E1

E1

E2a

Saxifraga cuneifolia

Hieracium murorum

Maianthemum bifolium

Larix decidua

Luzula luzulina

Luzula luzuloides

Melampyrum sylvaticum

Luzula pilosa

Homogyne alpina

TA Tilio-Acerion

Acer pseudoplatanus

Acer pseudoplatanus

$\mathrm{E} 2 \mathrm{~b}$

Acer pseudoplatanus

E2a

Acer pseudoplatanus

E1

Adoxa moschatellina

E1

E1

E1

E1

E1

Polystichum braunii

E1

E2

E1

E1 
FS Fagetalia sylvaticae

Lonicera alpigena

Paris quadrifolia

Dryopteris filix-mas

Daphne mezereum

Melica nutans

Fagus sylvatica

Mercurialis perennis

Poa nemoralis

Actaea spicata

Symphytum tuberosum

Fagus sylvatica

$\begin{array}{lll}1 & 2 & 3\end{array}$

4

56

Fagus sylvatica

Epilobium montanum

E2a

Galeobdolon flavidum

Pulmonaria officinalis

Myosotis sylvatica agg.

Lilium martagon

Viola reichenbachiana

E1

E1

E2a

E1

E2a

E1

E1

E1

E1

E2b

E1

E1

E1

E1

E1

E1

E1

Galium laevigatum

Luzula nivea

E1

E1

Laburnum alpinum

Phyteuma spicatum subsp. coeruleum

E2

E1

Asarum europaeum subsp. caucasicum

Scrophularia nodosa

Lathyrus vernus

Festuca altissima

Fraxinus excelsior

QP Quercetalia pubescenti-petraeae

Oxalis acetosella

Convallaria majalis

Sorbus aria

Melittis melissophyllum

Fraxinus ornus

QF Querco-Fagetea

Anemone nemorosa

Hepatica nobilis

Lonicera xylosteum

Corylus avellana

Listera ovata

Carex digitata

O Other species (Druge vrste)

Hieracium sp.

Festuca sp.

ML Mosses and lichens (Mahovi in lišaji)

Tortella tortuosa

Ctenidium molluscum

Rhytidiadelphus triquetrus

Hylocomium splendens

Dicranum scoparium

Orthothecium rufescens

Sanionia uncinata

E1

E1

E2

E1

E1

E1

E2a

E2a

E1

E1

E1

E1

\begin{tabular}{l|ccccc|}
\cline { 2 - 6 } E0 & 1 & 1 & $\cdot$ & + & 1 \\
E0 & $\cdot$ & + & $\cdot$ & + & $\cdot$ \\
E0 & + & + & 1 & 1 & 1 \\
E0 & $\cdot$ & 1 & 1 & $\cdot$ & $\cdot$ \\
E0 & $\cdot$ & 1 & 1 & + & $\cdot$ \\
E0 & $\cdot$ & 1 & 1 & + & + \\
E0 & 1 & 1 & 1 & 2 & 1 \\
\cline { 2 - 6 }
\end{tabular}




\section{(19.}


Number of relevé (Zaporedna številka popisa)

$\begin{array}{llllllllll}1 & 2 & 3 & 4 & 5 & 6 & 7 & 8 & 9 & 10\end{array}$

Fissidens dubius

E0

Schistidium apocarpum

Peltigera canina

Polytrichum formosum

Hypnum cupressiforme

Marchantia polymorpha

Mnium sp.

Peltigera leucophlebia

Rhytidiadelphus loreus

Plagiomnium undulatum

Encalypta streptocarpa

Plagiochila porelloides

Conocephalum conicum

Pseudoleskeella catenulata

Rhizomnium punctatum

Mnium thomsonii

Solorina saccata

Neckera crispa

Polytrichum sp.

Muscisp.

Bryum capillare

Eurhynchium zetterstedtii

Plagiothecium undulatum

Thuidium tamariscinum

Cladonia sp.

Cladonia pyxidata

Ditrichum flexicaule

Homalothecium philippeanum

Bryum sp.

Dicranum sp.

Homalothecium lutescens

Radula sp.

Cetraria islandica

Cladonia fimbriata

E0

Cladonia furcata

E0

Squamarina sp.

E0

\section{Legend - Legenda}

1-5 Heliospermo pusillae-Rhododendretum hirsuti

6-12 Homogyno sylvestris-Salicetum glabare

13-28 Rhododendro hirsuti-Salicetum appendiculatae

Pr. Presence (number of relevés in which the species is presented) - število popisov, v katerih se pojavlja vrsta

Fr. Frequency in $\%$ - frekvenca $\mathrm{\%}$

E2a Lower shrub layer - spodnja grmovna plast

E2b Upper shrub layer - zgornja grmovna plast

ID Igor Dakskobler

A Limestone - apnenec

D Dolomite - dolomit

Gr Gravel - grušč

Li Lithosol - kamnišče

Re Rendzina - rendzina 


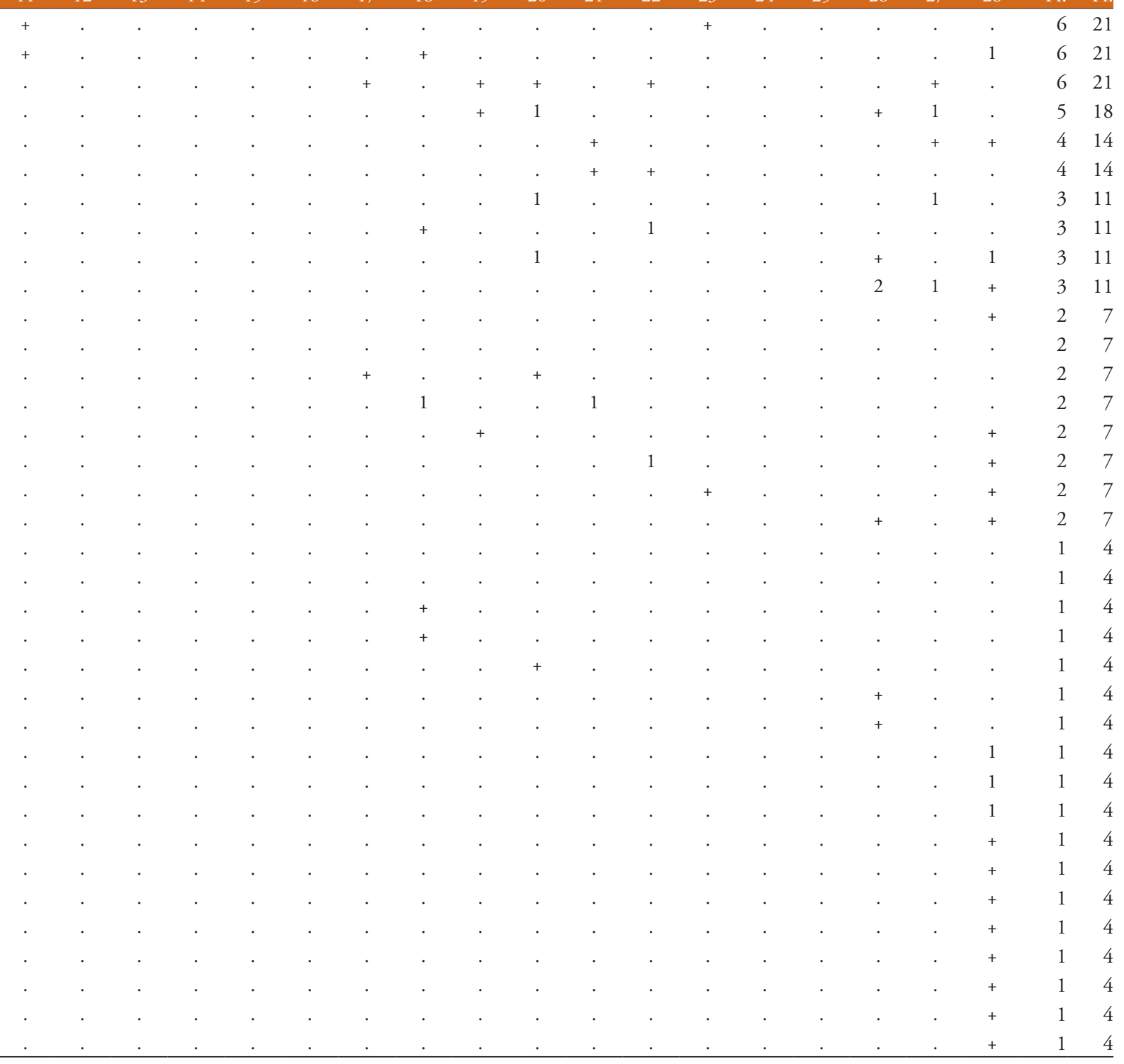




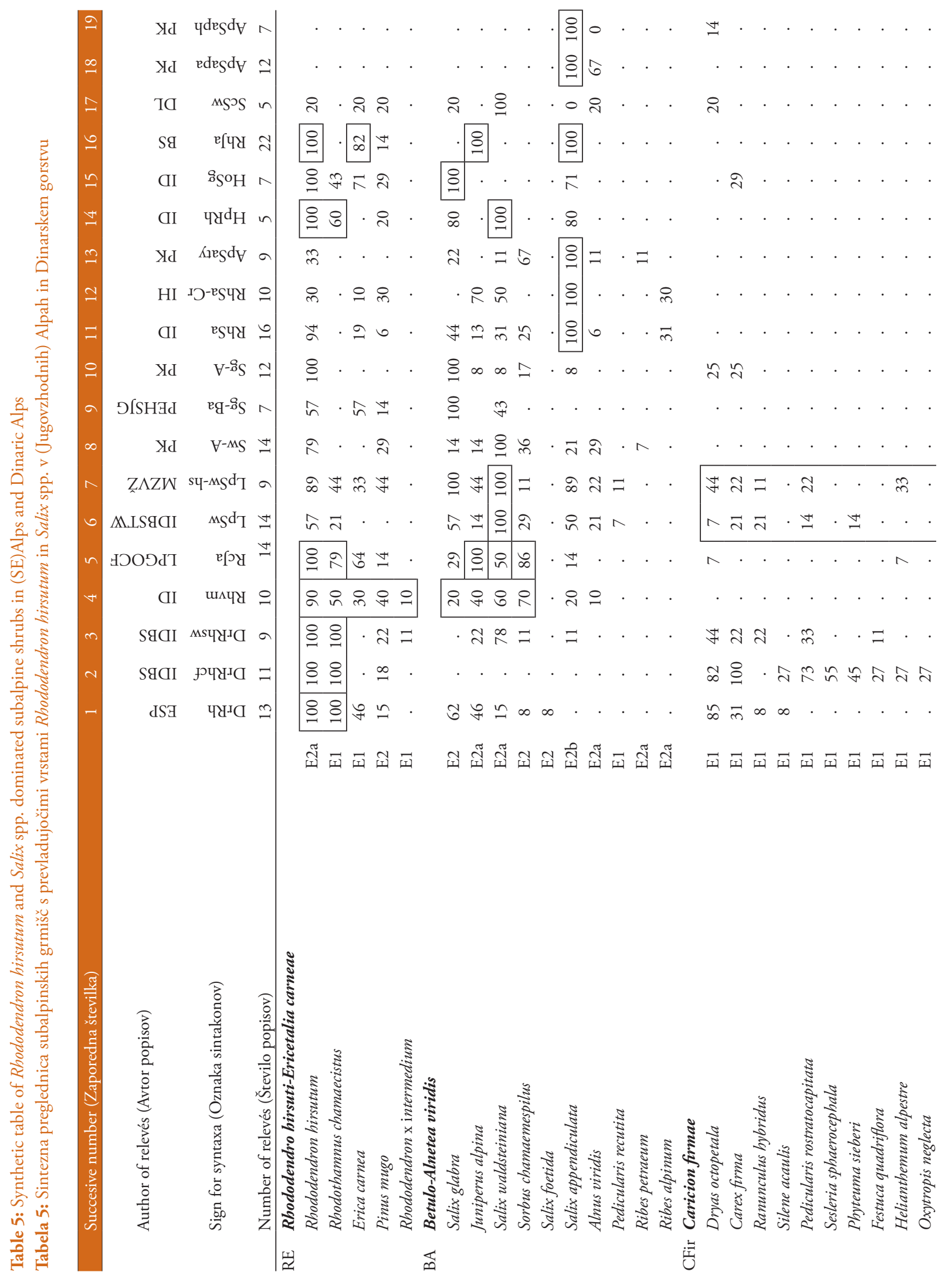



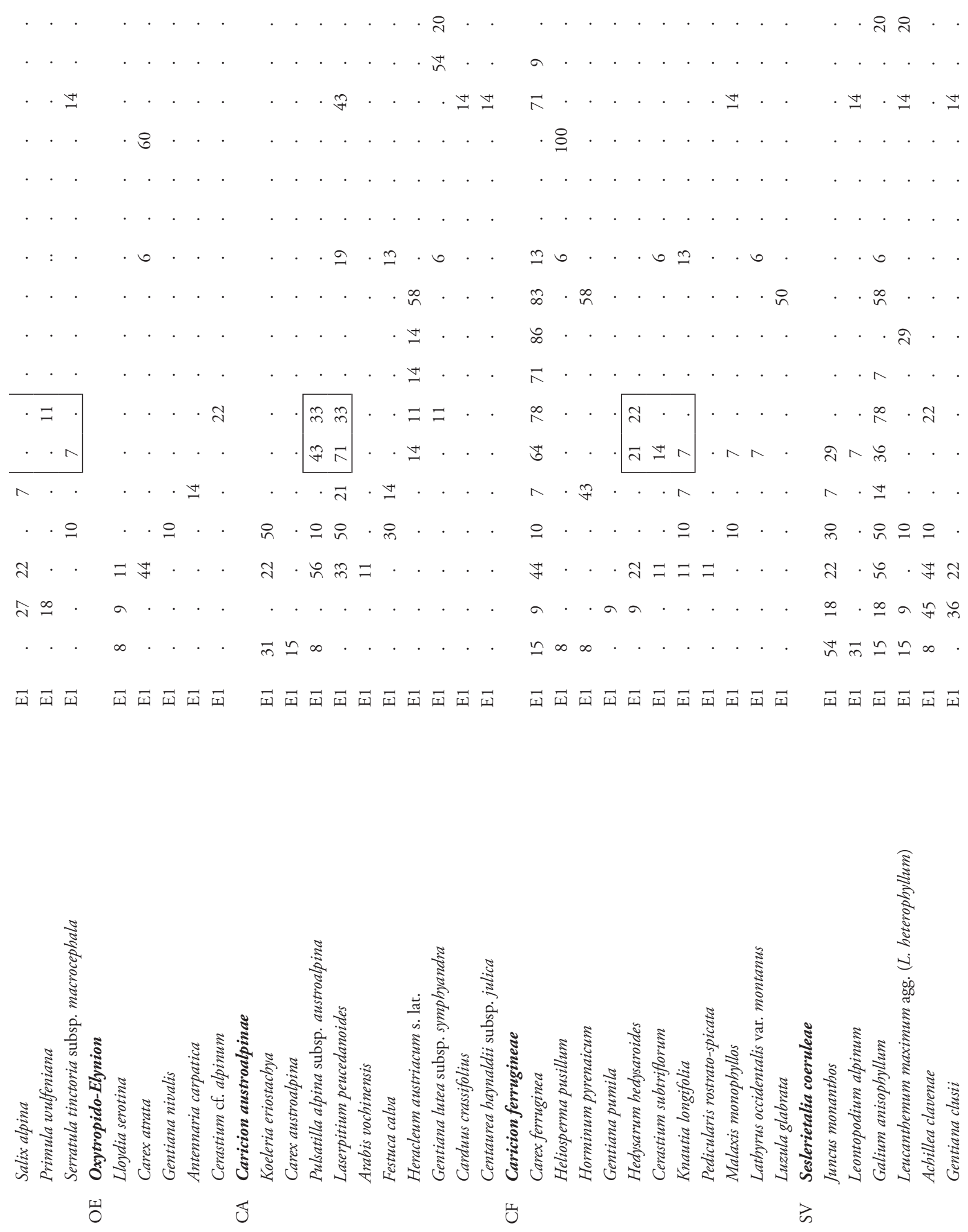


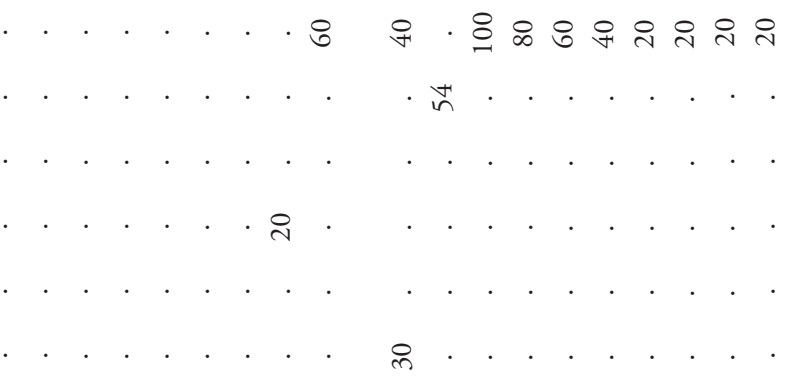
\& ำ. ㅇำ $\infty$ ลิ

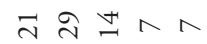

$$
\begin{aligned}
& \text {. . . उ } \\
& \text {. } \\
& \text {. . } 8 \\
& \text {. . ส } \\
& \text {. . } \\
& \ddot{m} \cdot \vec{n}
\end{aligned}
$$

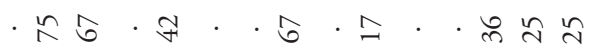

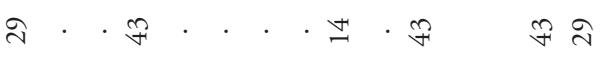

$$
\begin{aligned}
& \text {. } \\
& \vec{\lambda} \cdot \stackrel{i}{i} \cdot n
\end{aligned}
$$

우

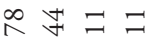

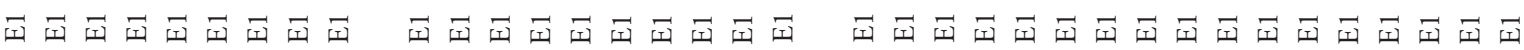

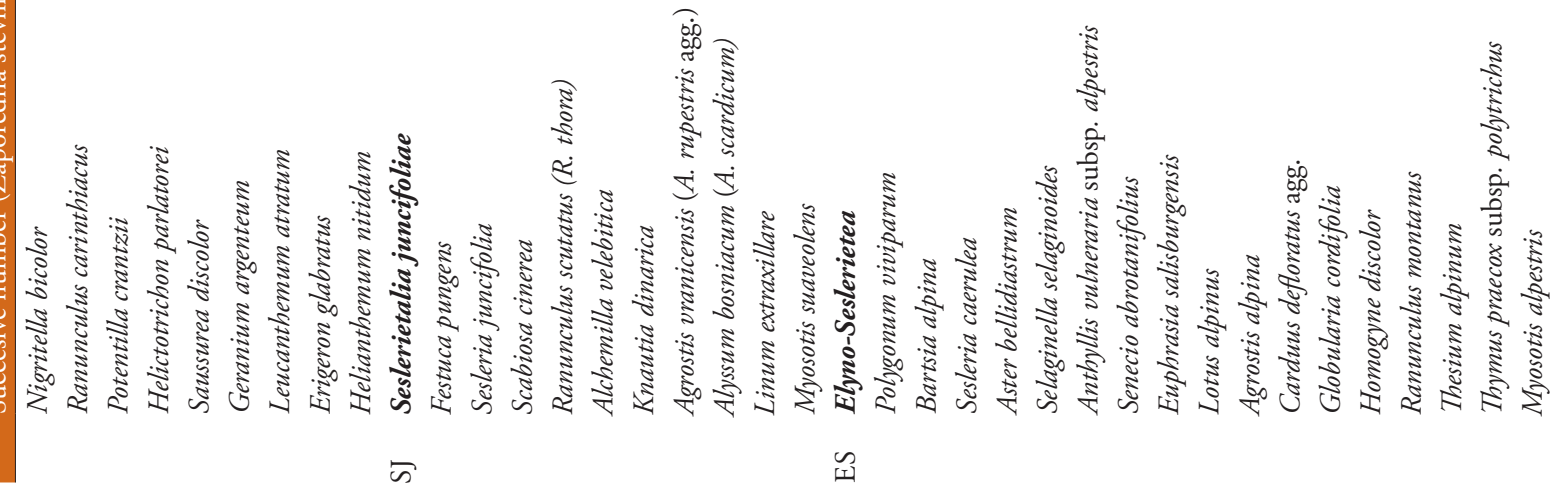



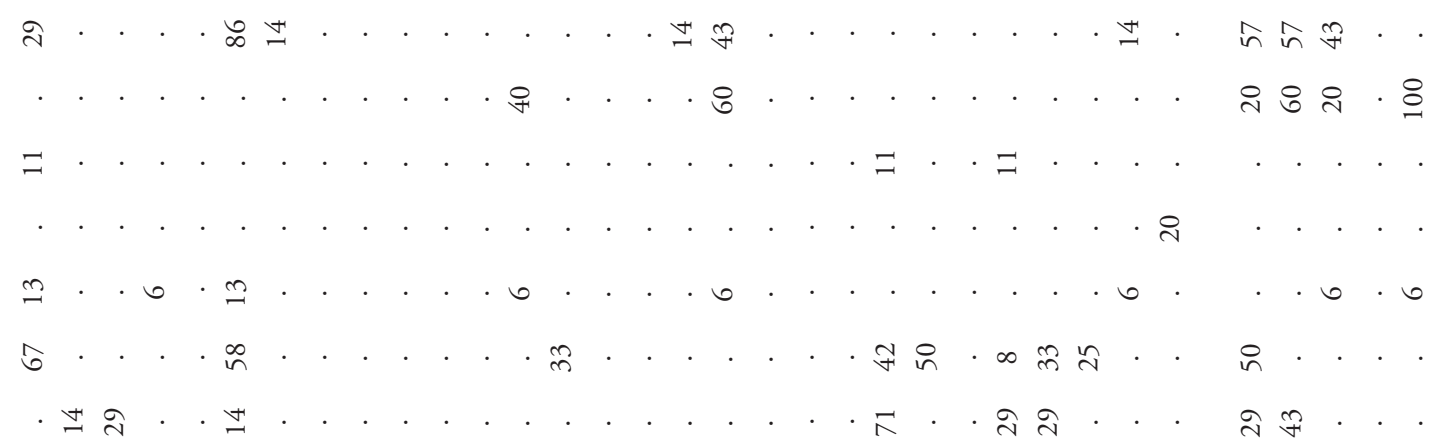

$\stackrel{\wp}{n}$ $\cdot \overrightarrow{4} \cdot \sqrt[4]{4}$

过 $\cdot \approx$ กี $i n \hat{F}$

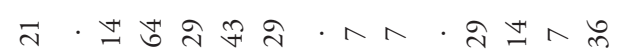
¿

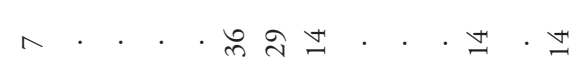

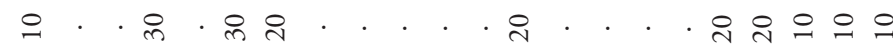

สี $=$ ก

$\stackrel{\infty}{\rightarrow} \stackrel{\infty}{\sim} \sigma a \sigma a \sigma a$ F্

$\infty \infty \infty$ in ते in

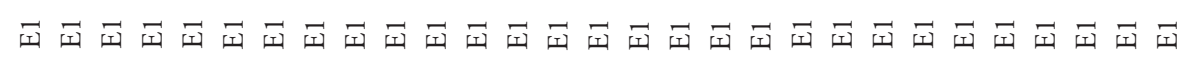

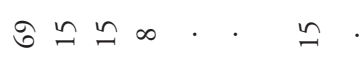

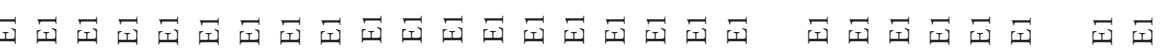

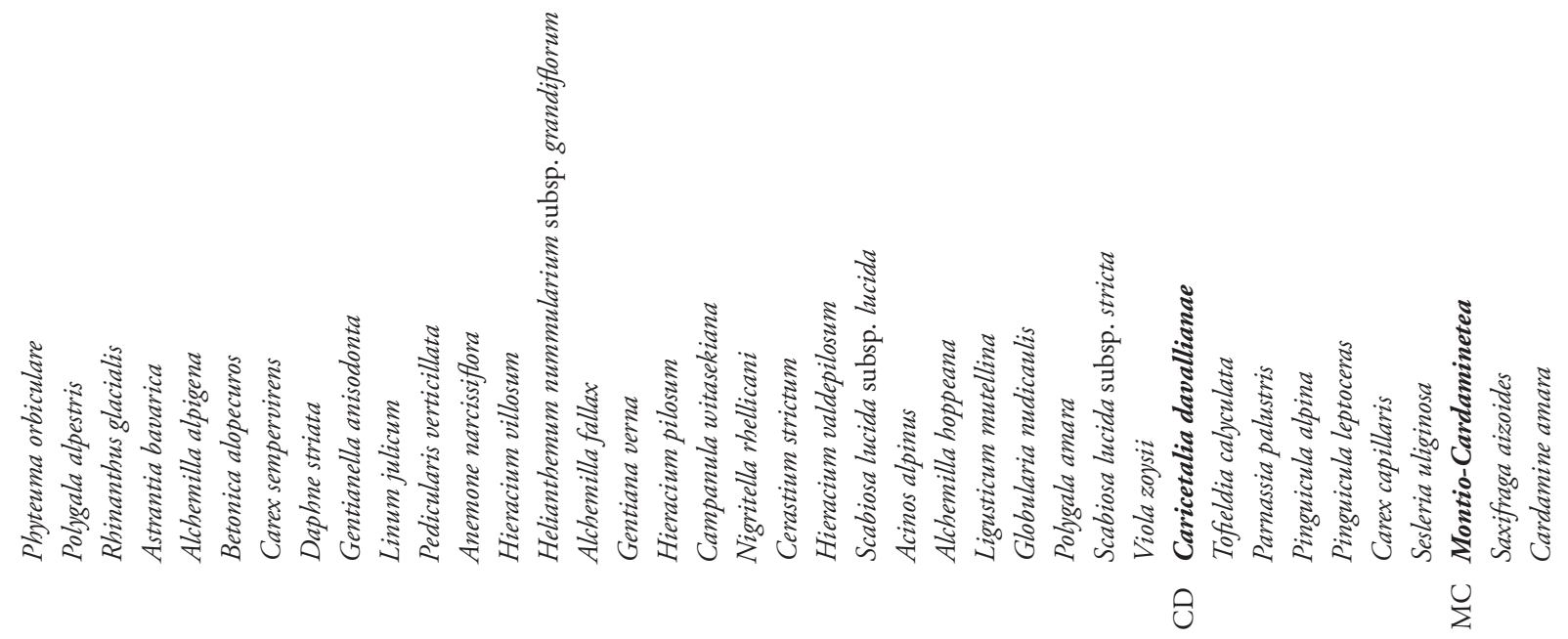




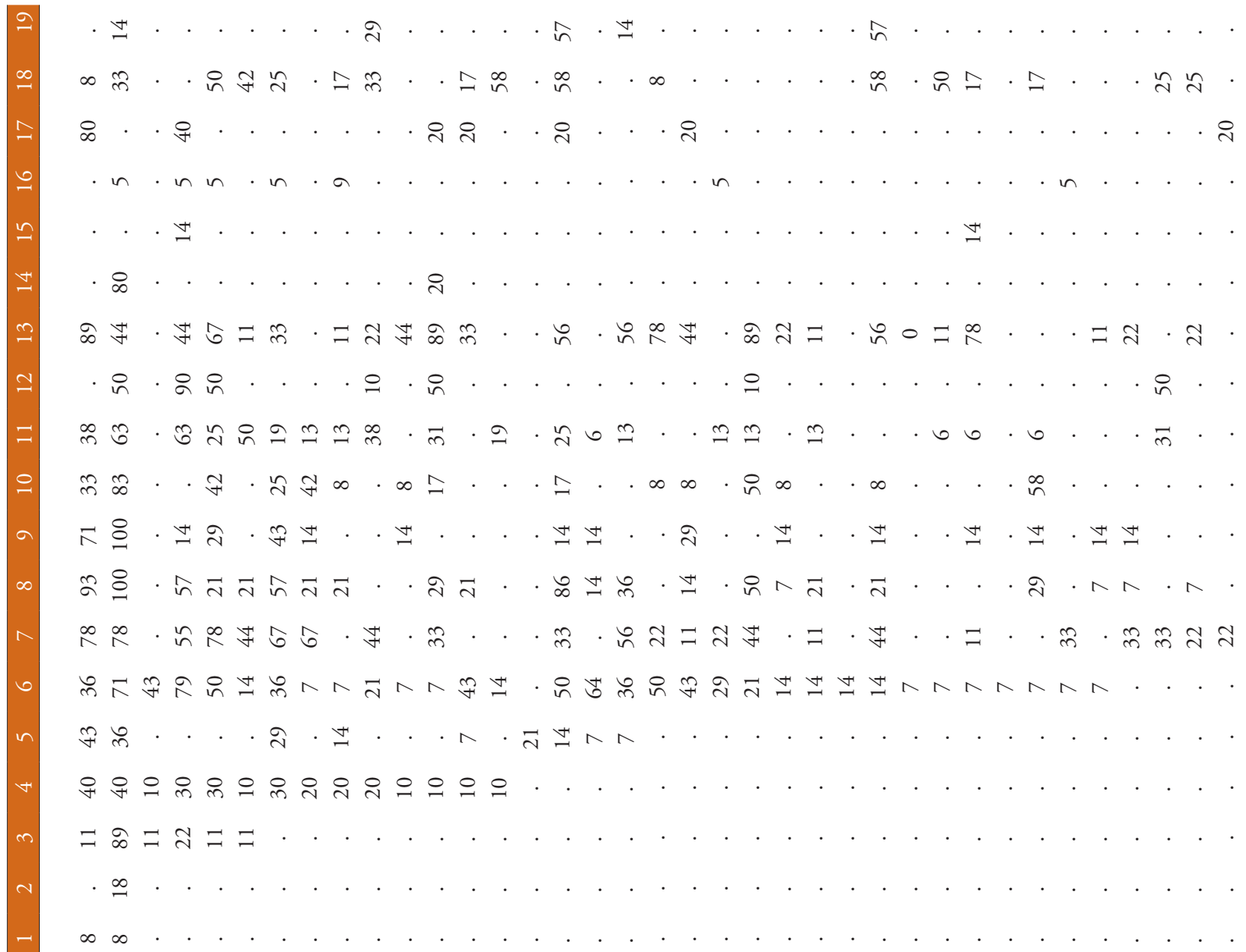

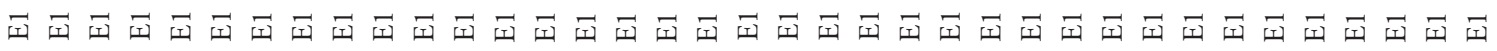




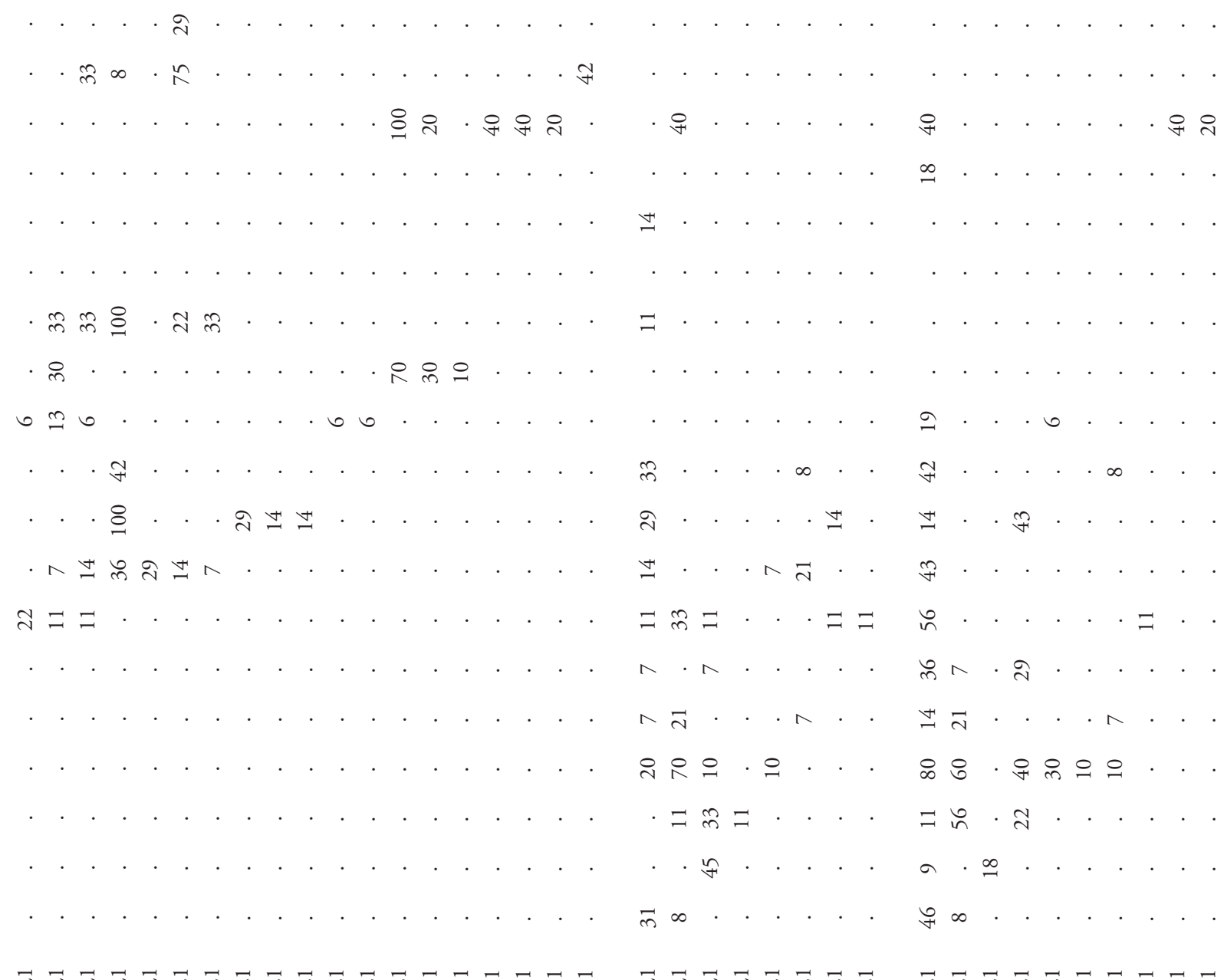

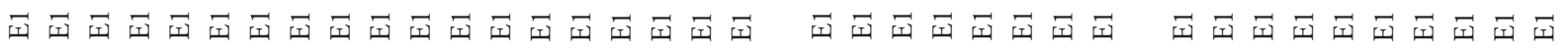

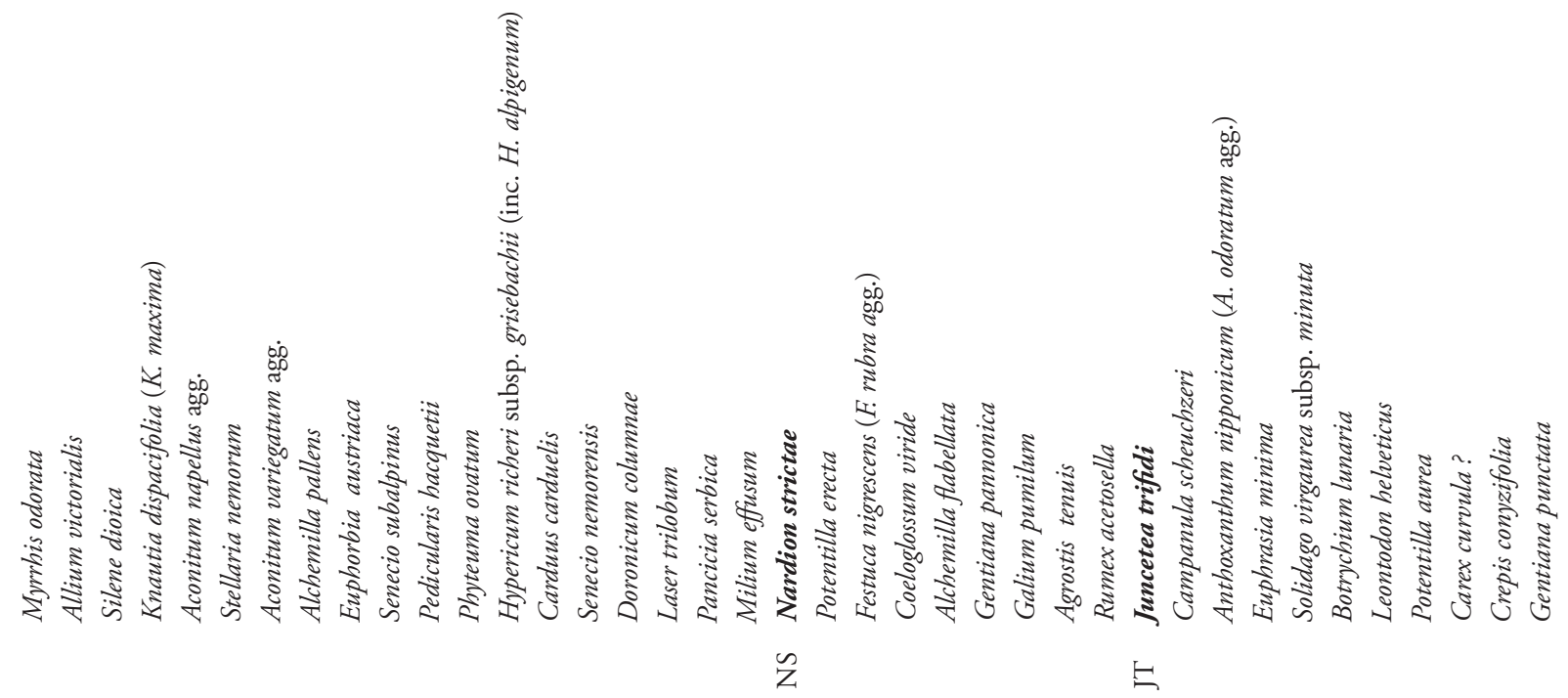




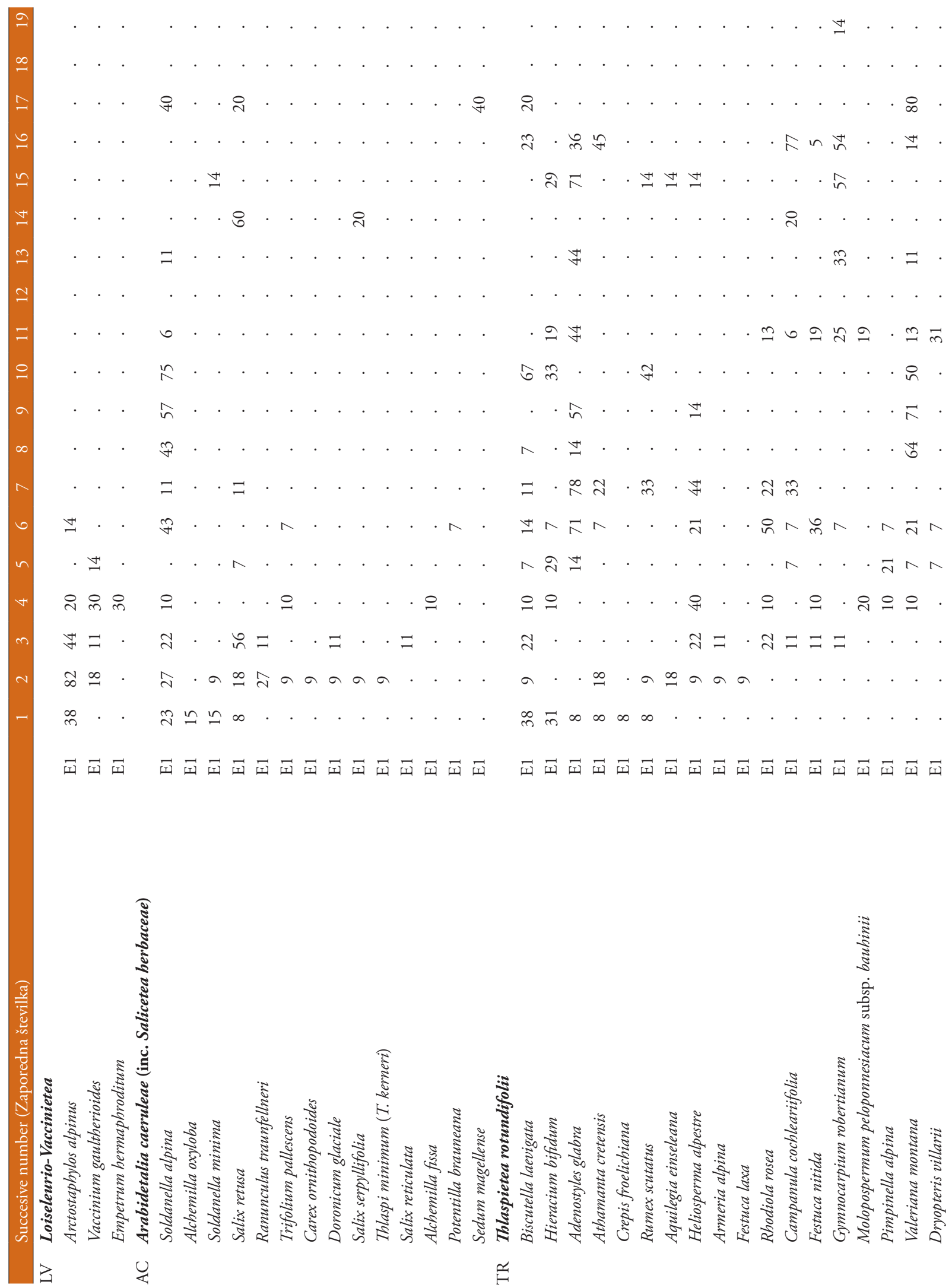




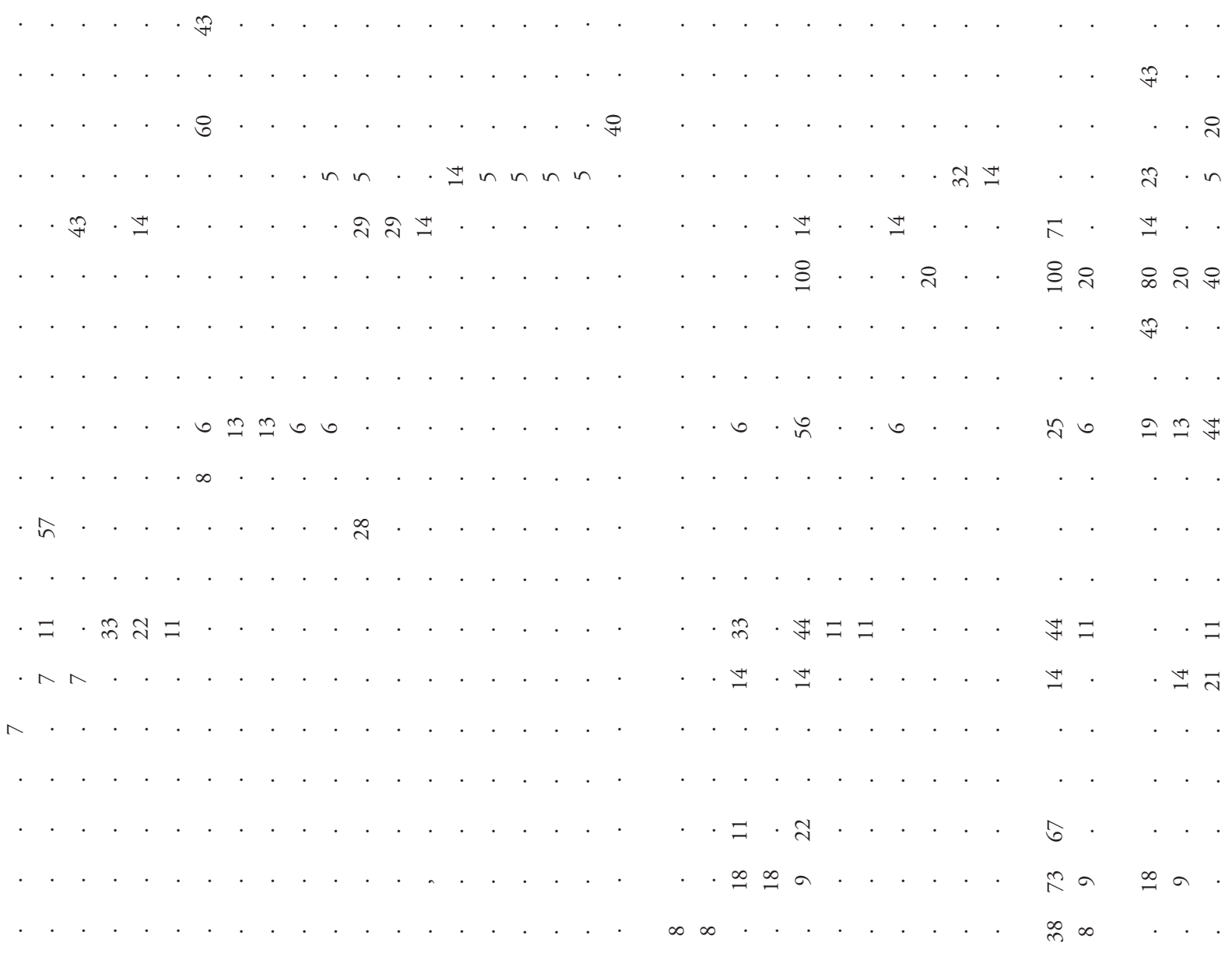

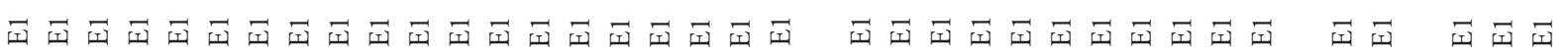

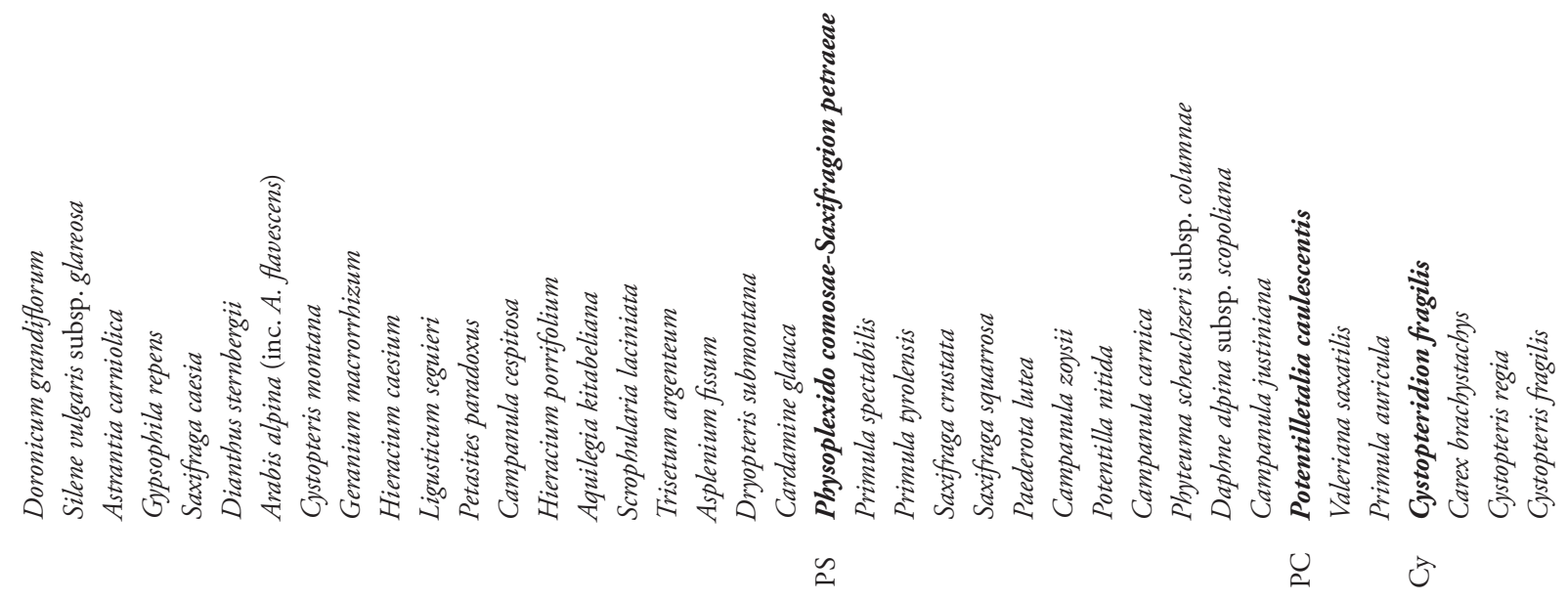



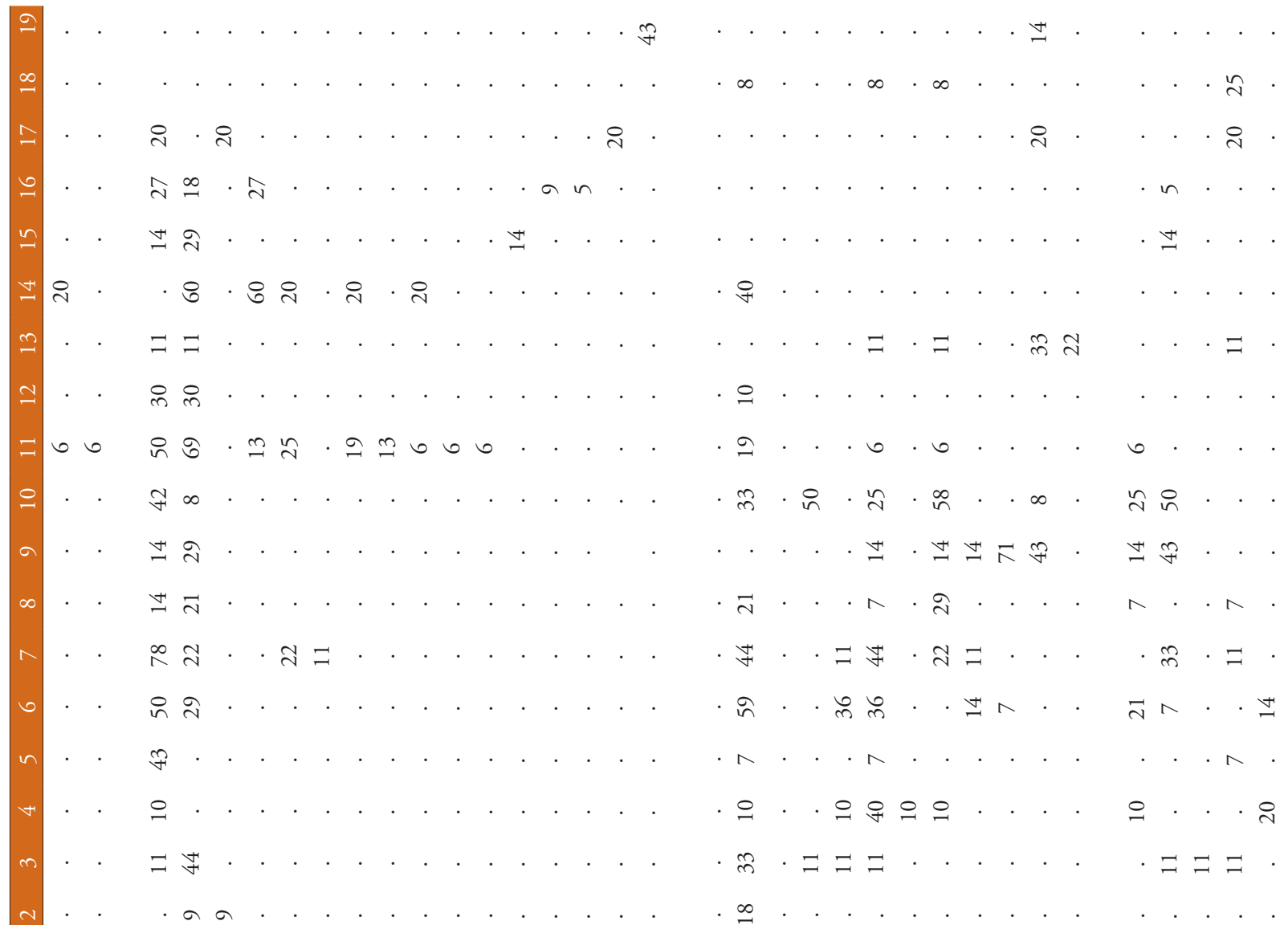

$\approx \sim \infty \infty \infty$

$\ddot{\sim} \cong \infty$

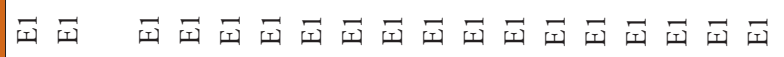

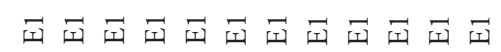

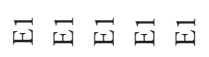

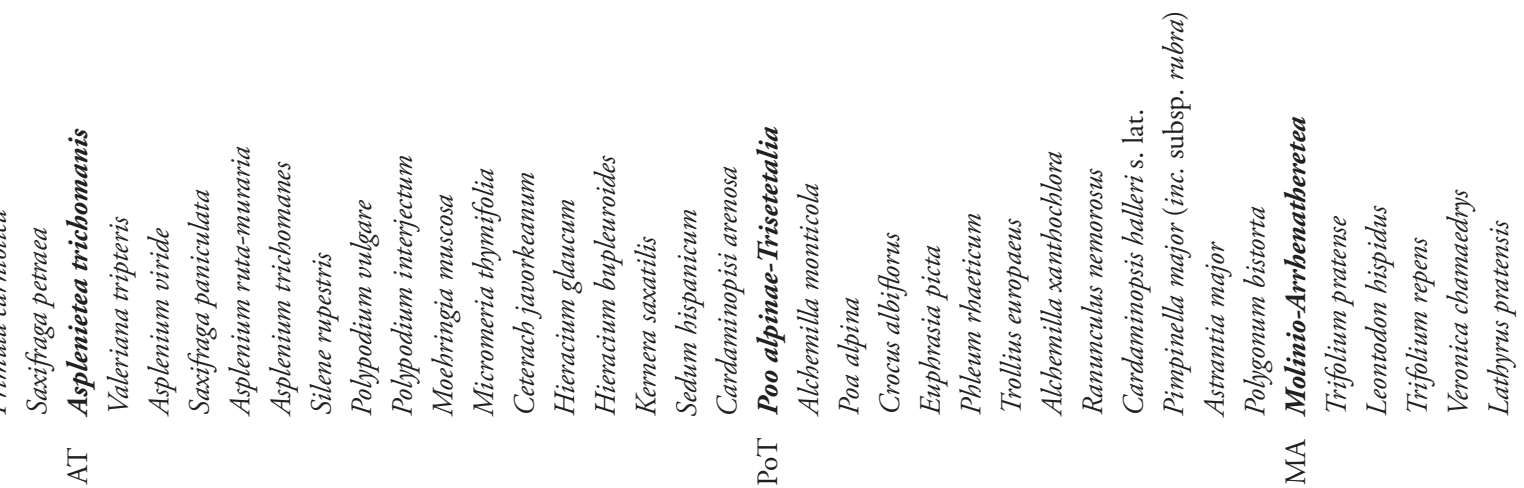




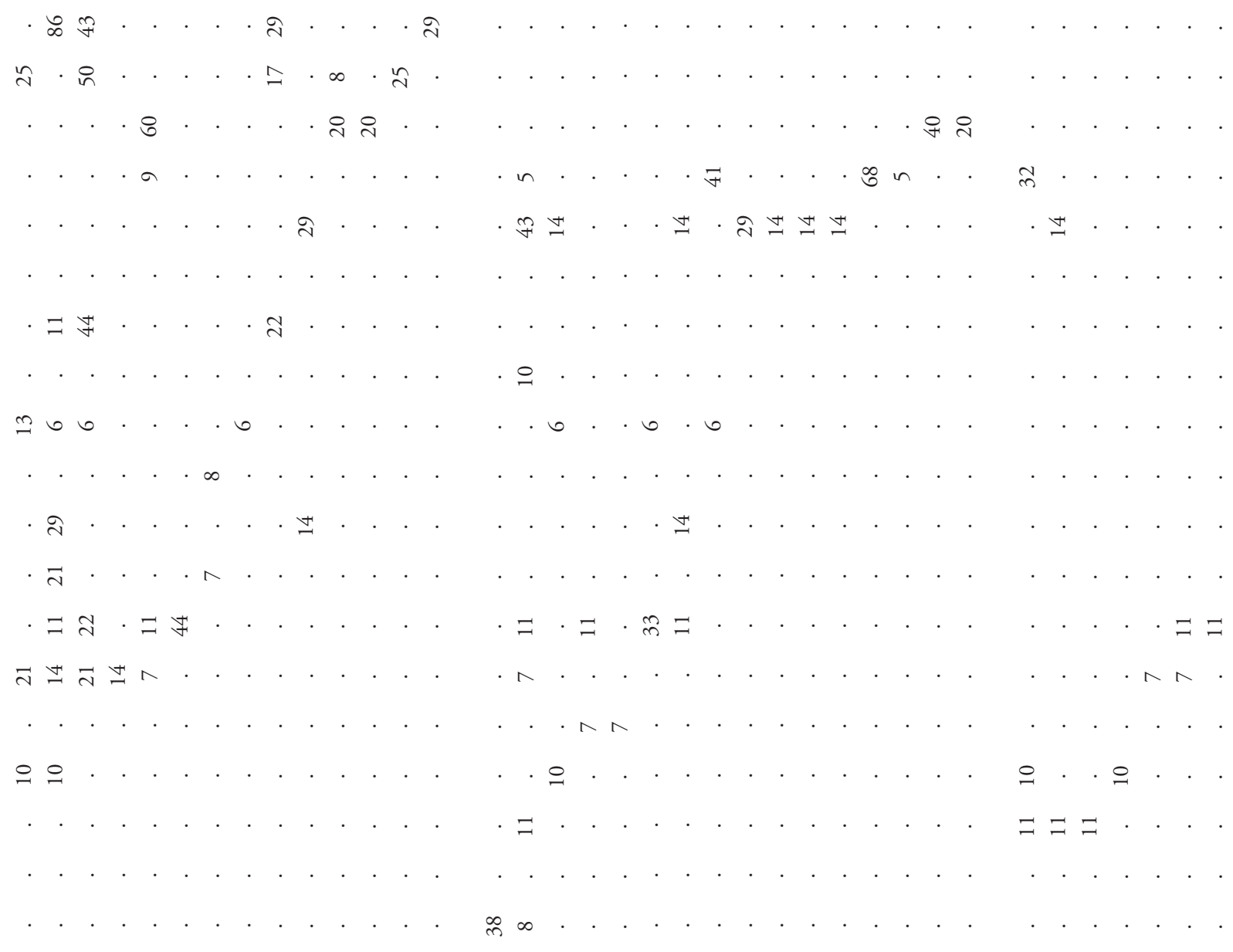

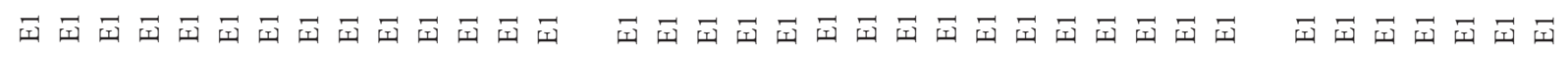

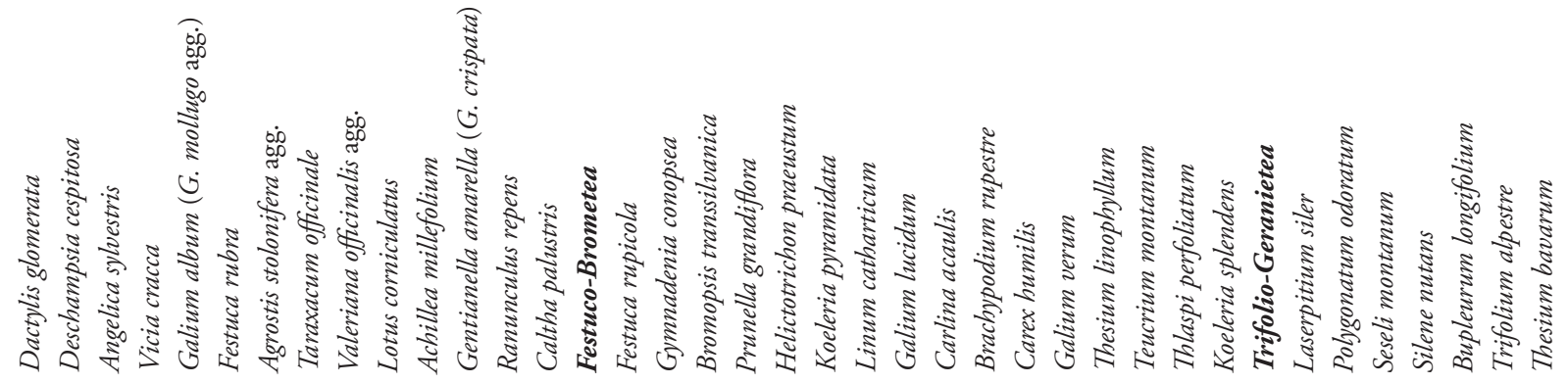




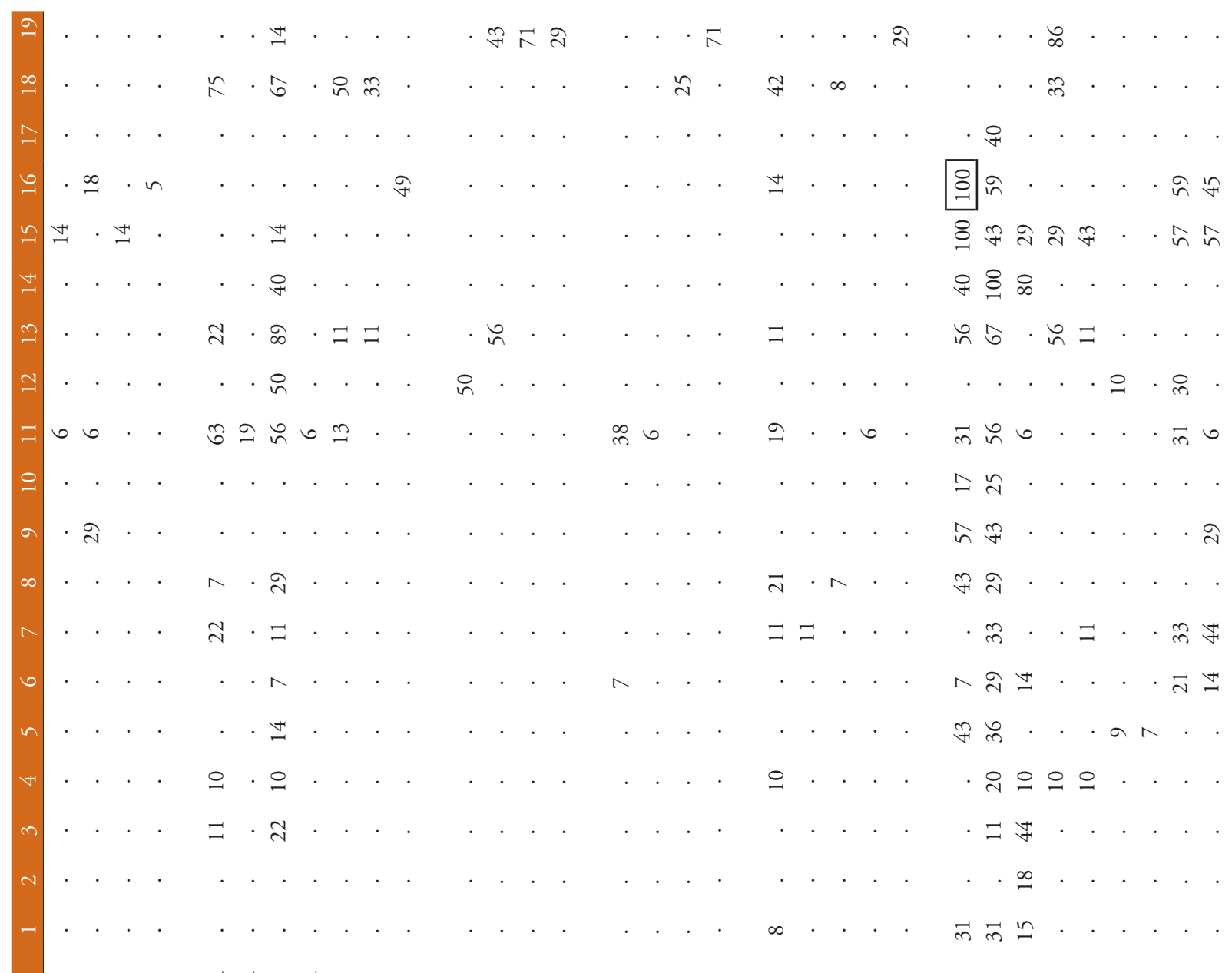

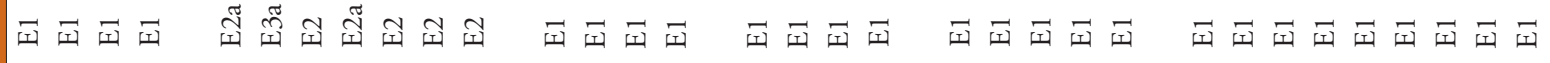

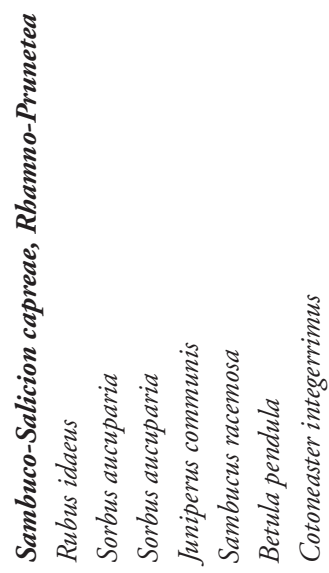

क

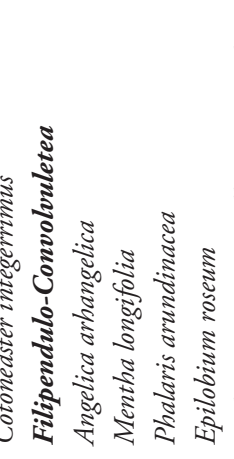

U
ปัँ

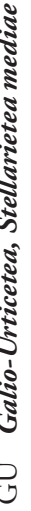

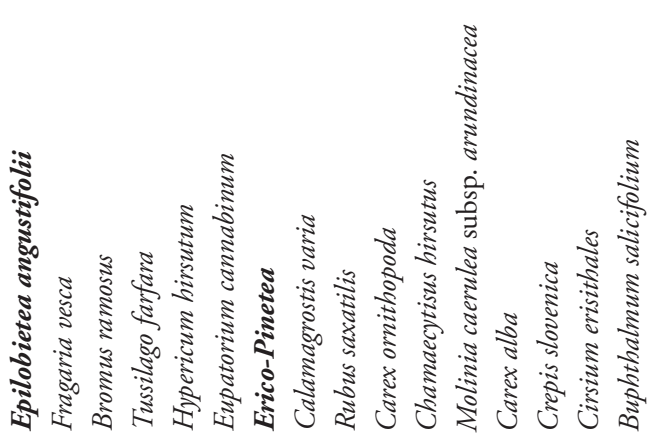
管
经 


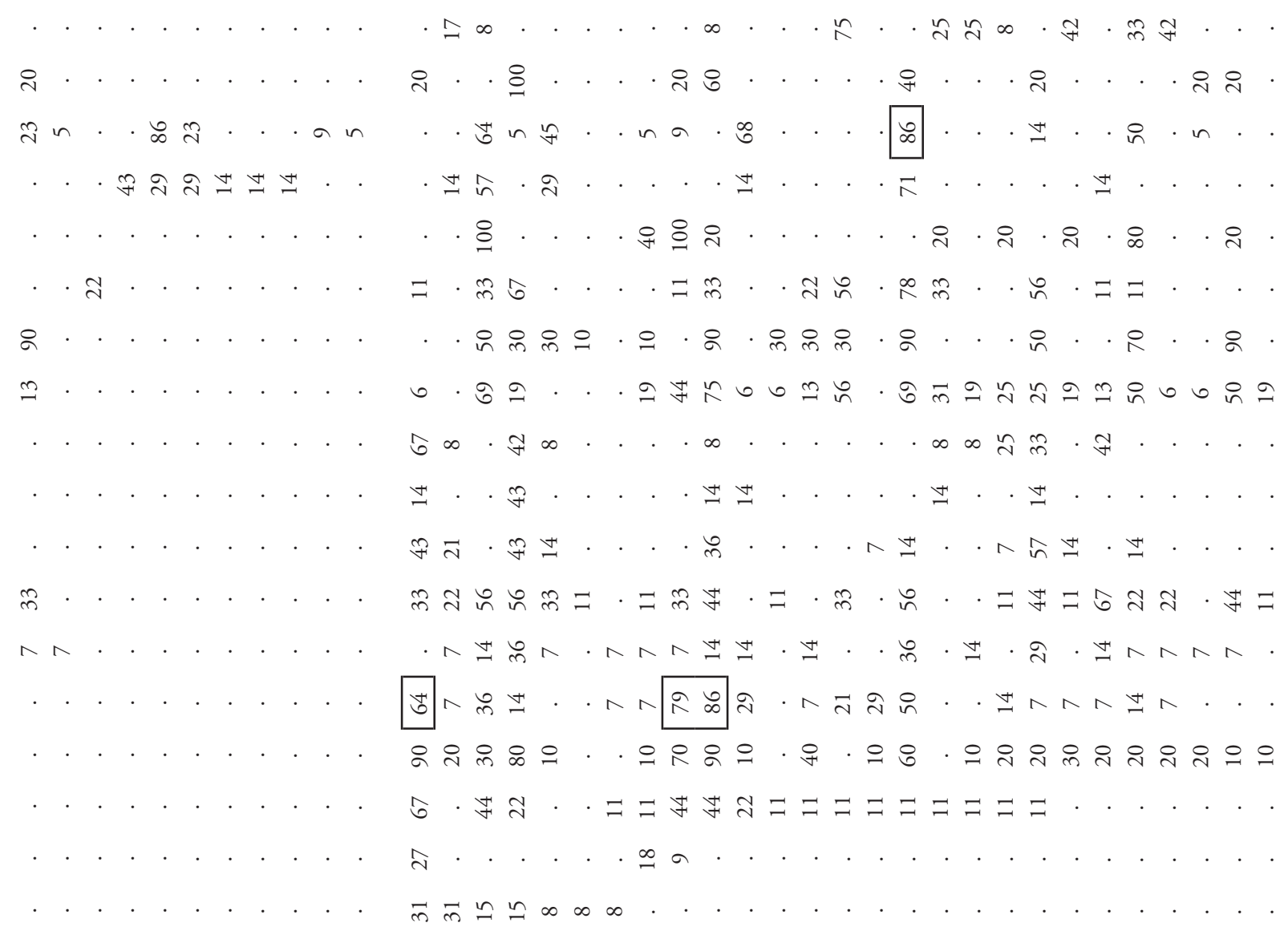

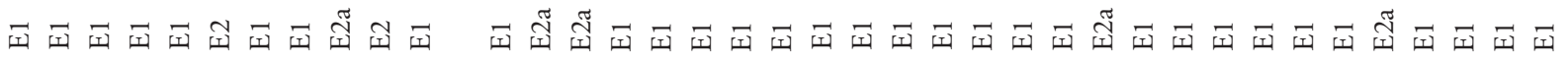

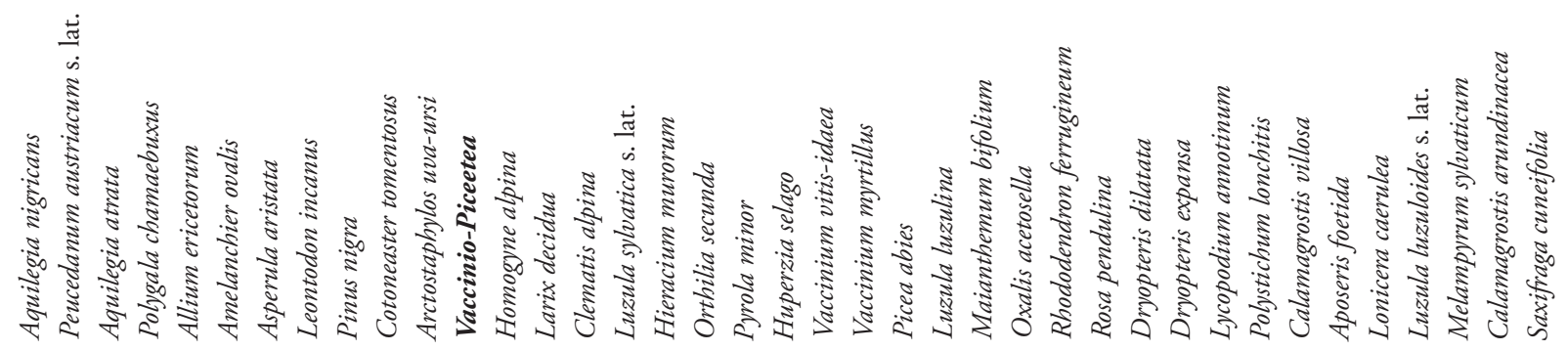




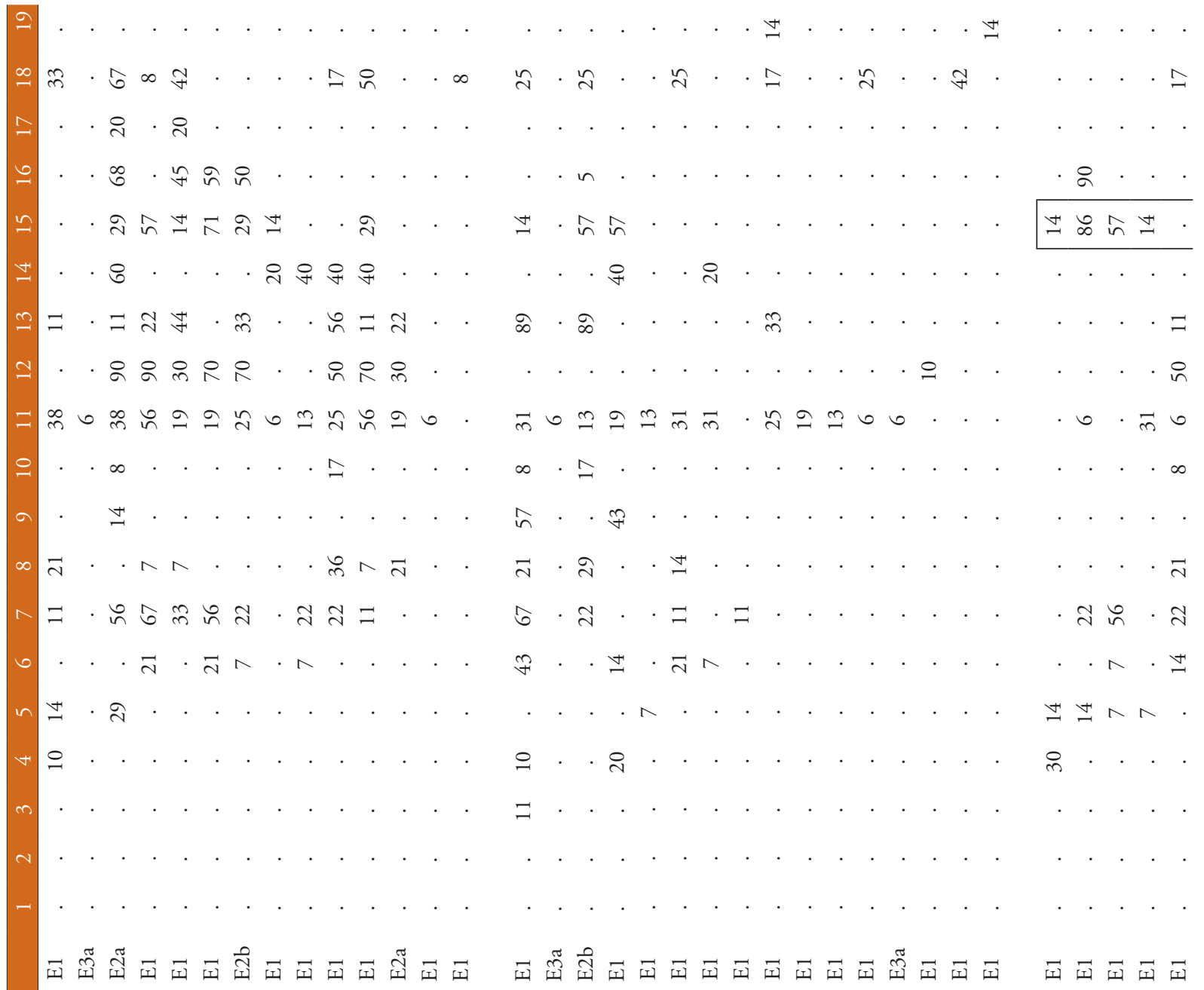




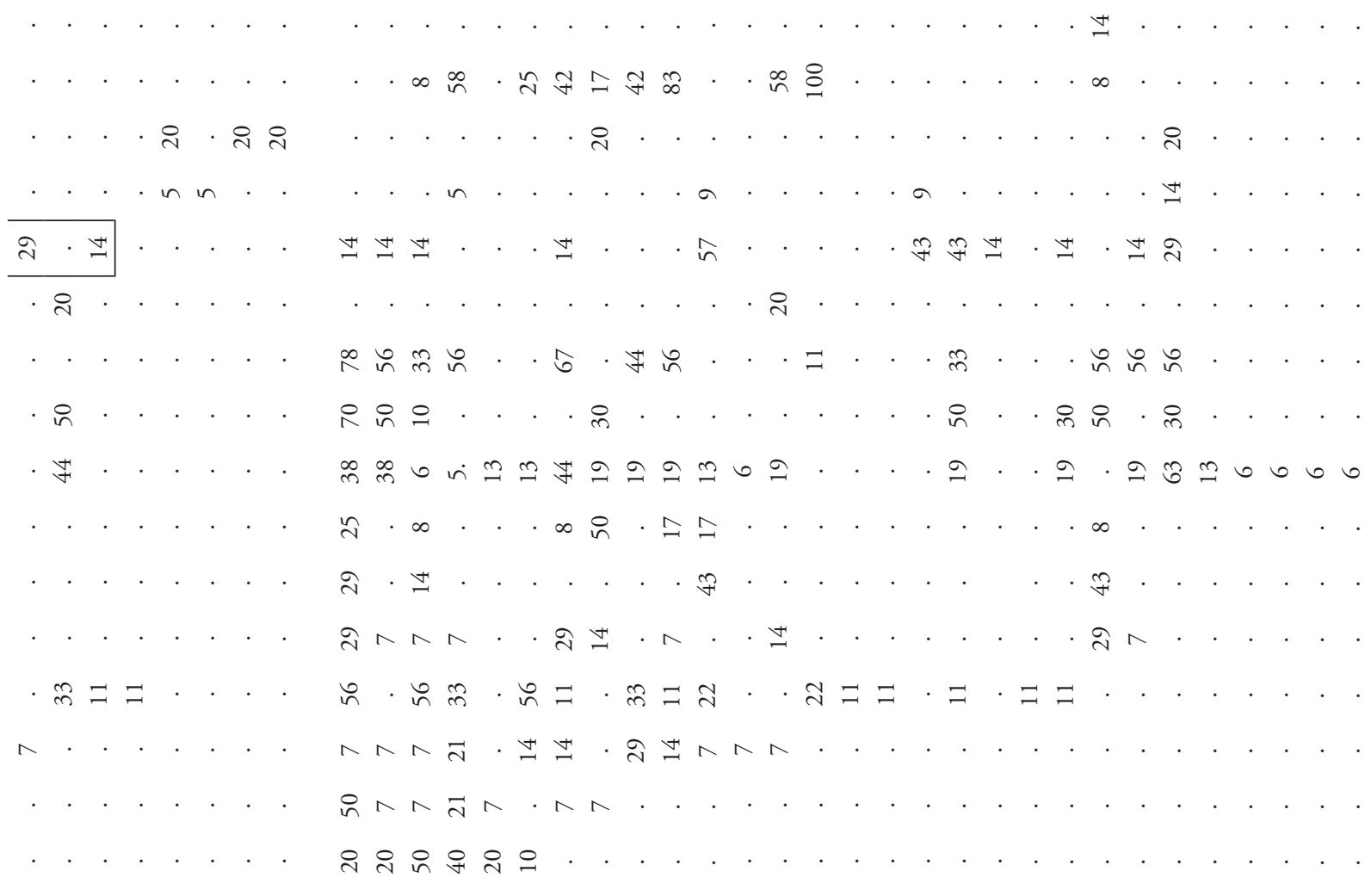

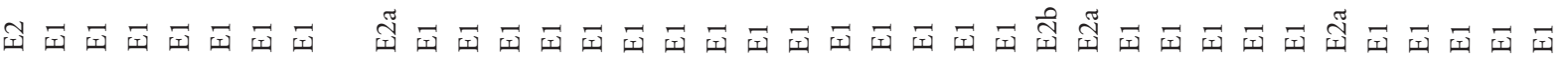

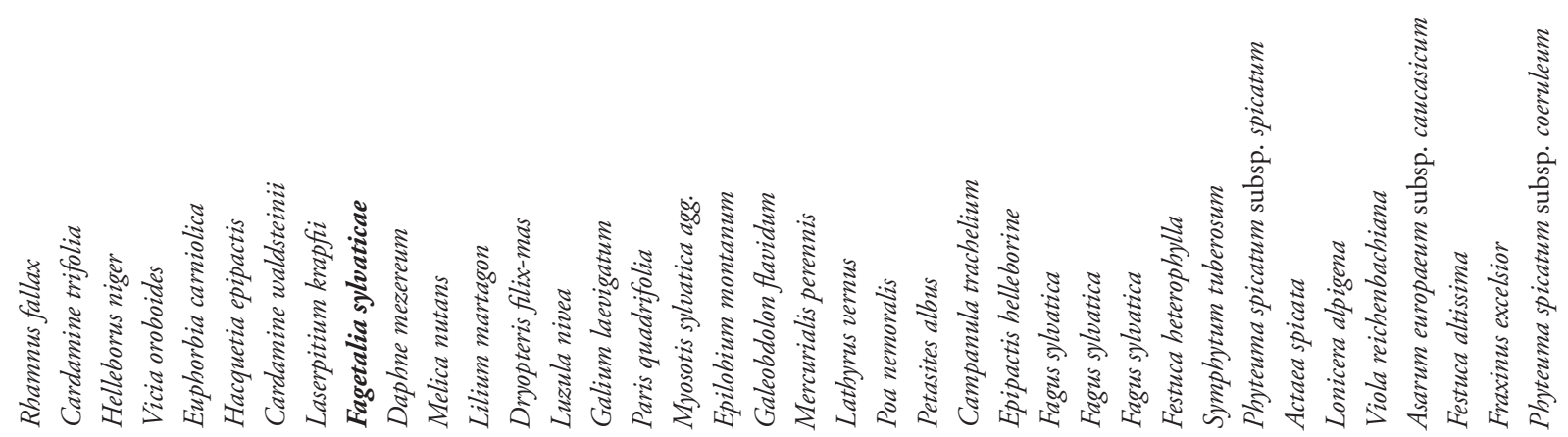




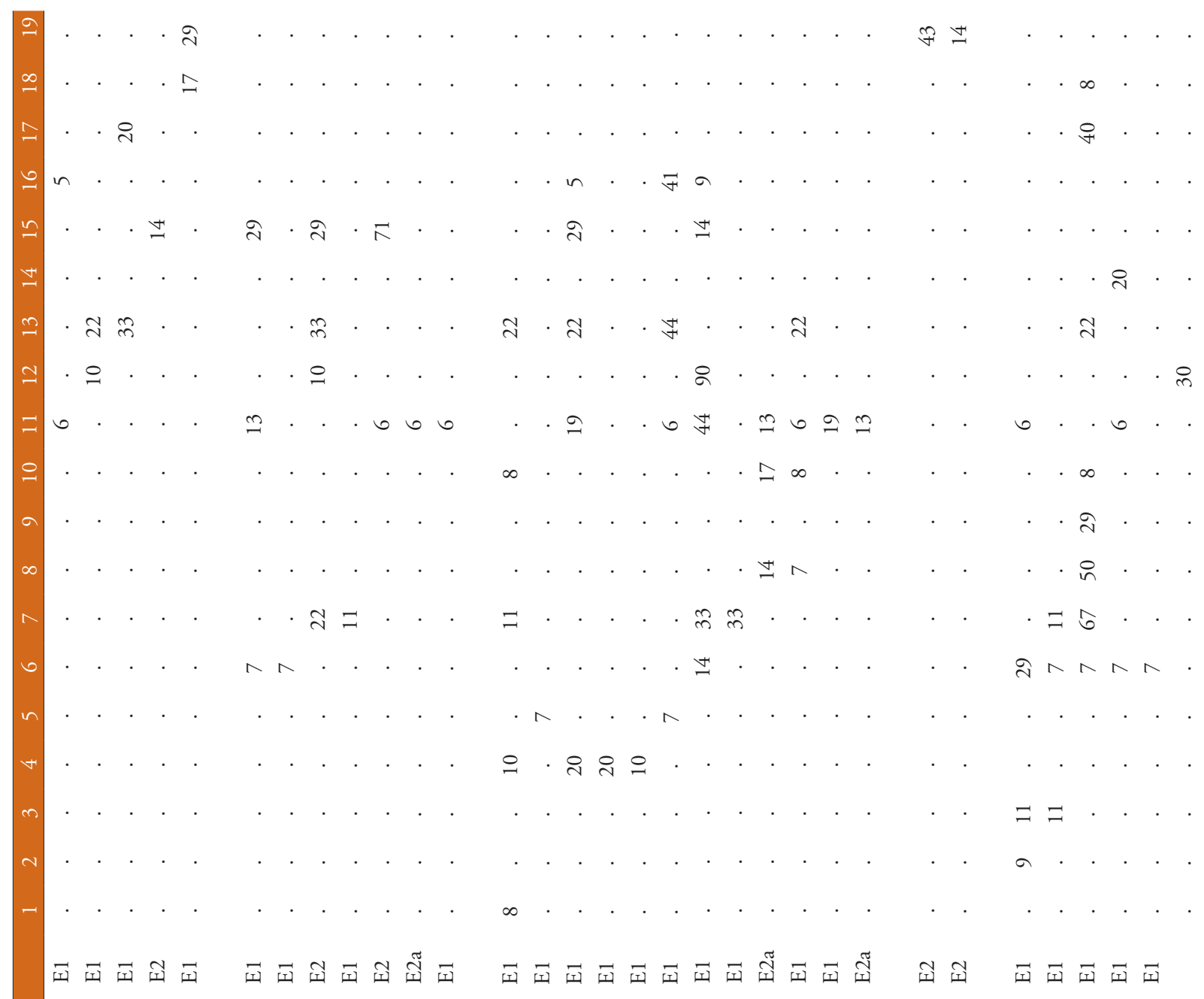




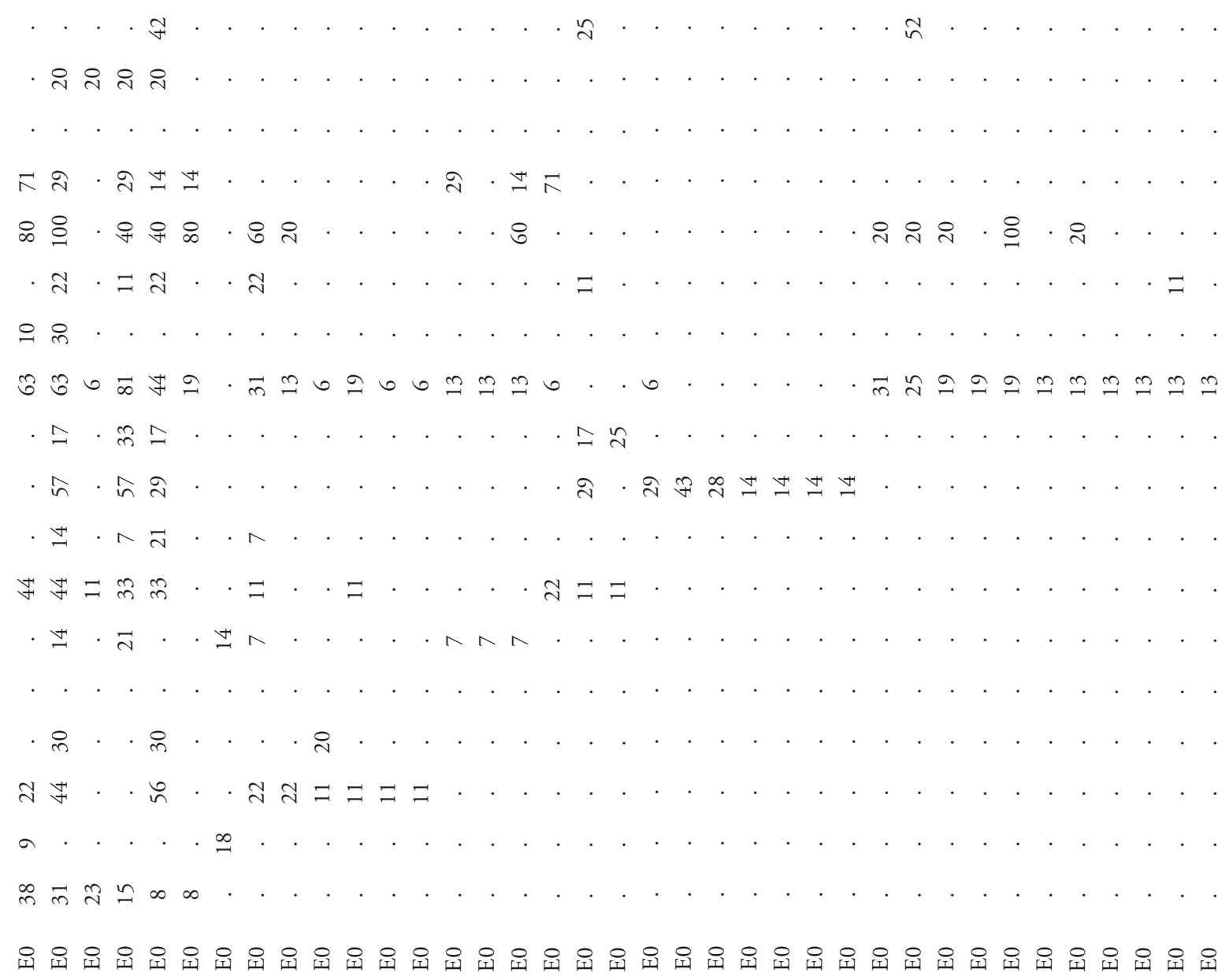



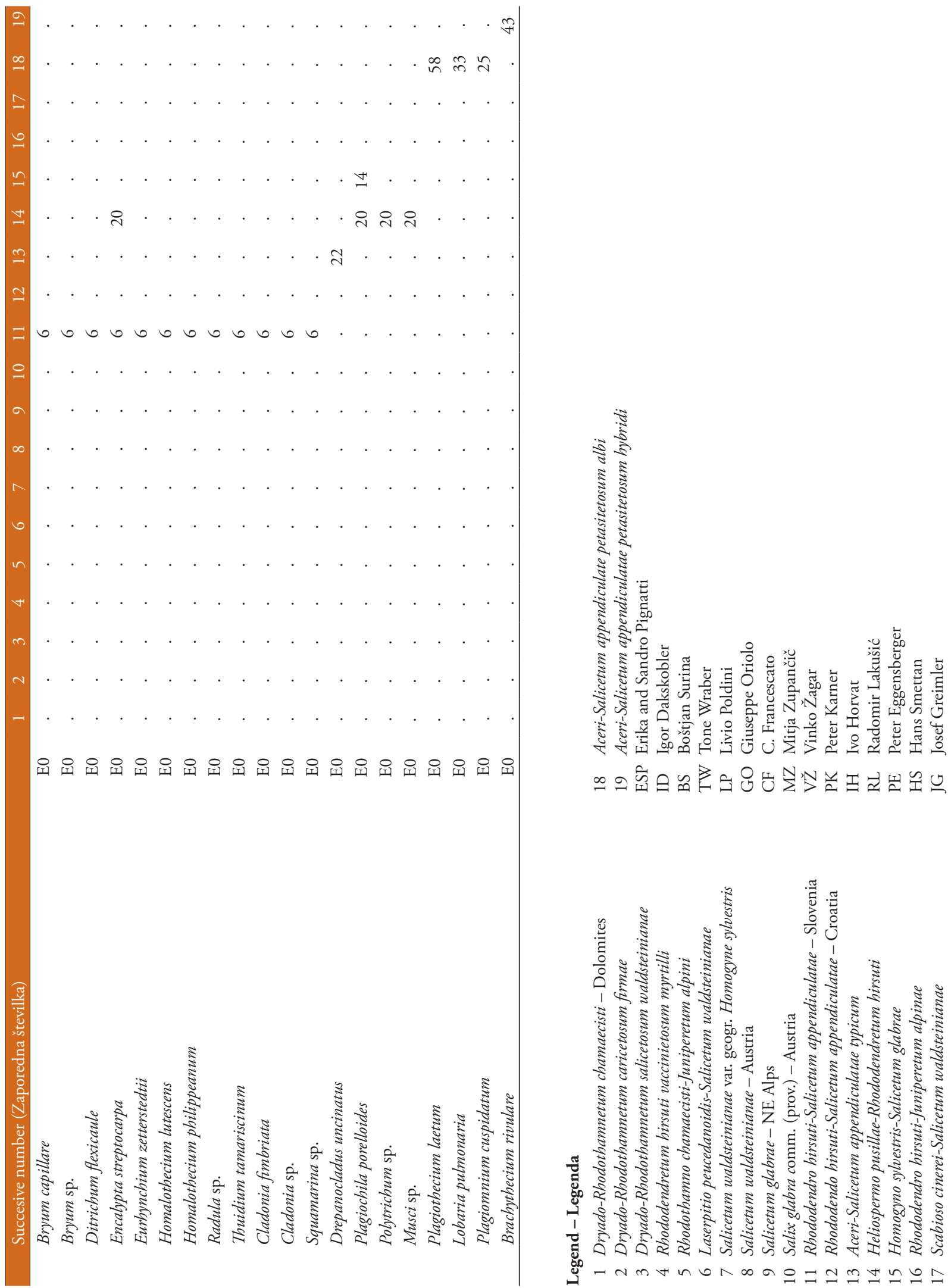


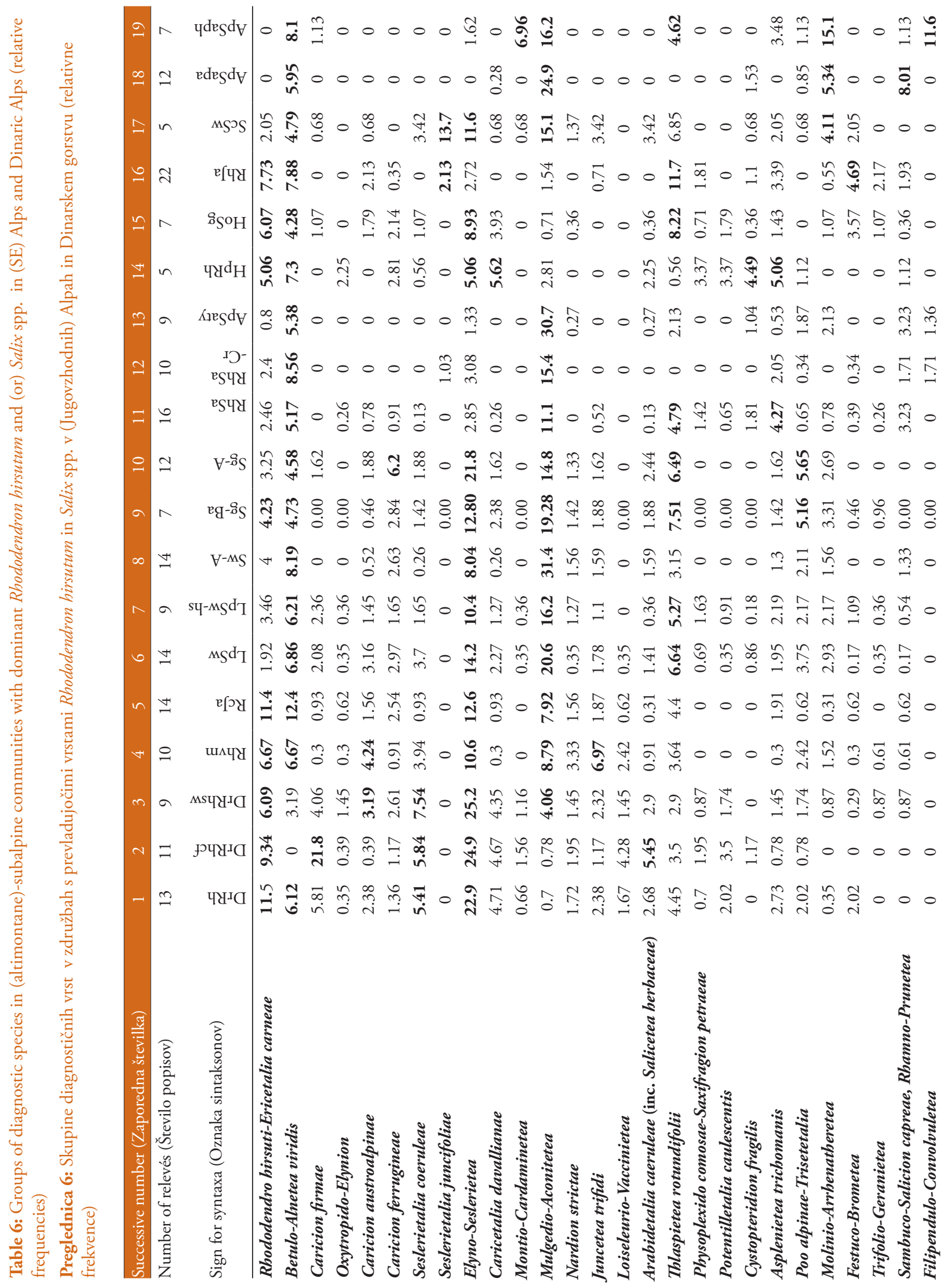




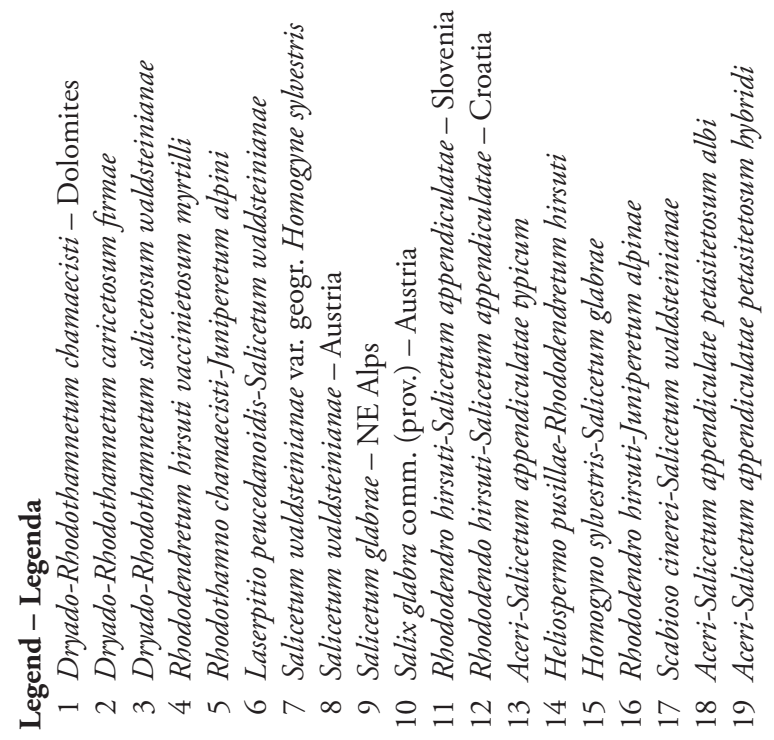

